\title{
Rewriting the Fiscal Constitution: The Case of Gramm-Rudman-Hollings
}

\author{
Kate Stith
}

\section{TABLE OF CONTENTS}

PAGE

Introduction: The Constitutional Ambition of Gramm-Rudman-

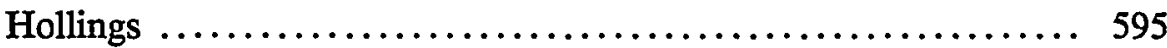

I. The Constitutional Budget Process Before Gramm-RudmanHollings ...................................... 599

A. The Federal Budget ....................... 600

B. The Relationship Between Withdrawal from the Treasury and Legislated Spending Authority ........ 603

1. Appropriations: The Distimction Between Outlays and Budget Authority.................... 603

2. Budget Authority Outside of Annual "Appropriations" Acts ..................... 605

C. Legislative Specification of the Details of Federal Spending ................................. 609

1. Early Efforts to Assert Legislative Control: "Line Itemization" .............................. 609

2. "Lump-Sum Appropriations" ............... 611

3. Committee Allocations and "Reprogramming".... 613

D. The Procedural Changes of 1974 ................ 615

II. The Challenge of Gramm-Rudman-Hollings ........... 621

A. The New Political Economy $\ldots \ldots \ldots \ldots \ldots \ldots \ldots \ldots 621$

B. The New Regime........................ 625

1. Stage One: The Budget Process.............. 625

2. Stage Two

a. Expenditure Ceiling $\ldots \ldots \ldots \ldots \ldots \ldots \ldots \ldots, 627$

b. Sequestration Rules .................... 630

III. Interstitial Changes in the Constitutional Budget Process ... 633

A. A Deficit-Driven Legislative Process .............. 634

B. The Relationship between Spending Authority and Outlays under Sequestration .................... 639

C. The Reemergence of "Line Itemization"........... 643

1. The Uniformity Requirement and Line Itemization ............................ 644 
2. The Significance of the "Program, Project, and Activity" Rule.............................. 645

3. The Status of Committee Reports under GrammRudman-Hollings ........................ 647

IV. The Enduring Fiscal Constitution................... 652
A. Gramm-Rudman-Hollings and the Structure of Federal Spending .............................. 652
B. Legislative Power Under Gramm-Rudman-Hollings.... 659
C. Conclusion: The Pohtical Budget Process............ 664 


\title{
Rewriting the Fiscal Constitution: The Case of Gramm-Rudman-Hollings
}

\author{
Kate Stith $\dagger$
}

\begin{abstract}
Because the Constitution's fiscal provisions are not self-executing, federal budget processes have been shaped largely by an implicit "fiscal constitution" composed of framework statutes and legislative and administrative practice. This Article contends that the ambition of the Gramm-RudmanHollings Act (GRH) was radically to redesign this constitution by creating an extralegislative mechanism ("sequestration") to enforce statutorily prescribed deficit limits. Professor Stith demonstrates how GRH alters several aspects of traditional practice: It makes the annual budget deficit the driving concern of the legislative budget process, it makes the timing of outlays critically important to appropriations decisions, and it encourages greater participation by Congress in line-item allocation of appropriations. $G R H$ does not, however, directly constrain spending in over half of the budget, which it exempts from sequestration. Moreover, there is an inherent limit to the effectiveness of sequestration as a deficit-reduction strategy. As the threat of sequestration becomes greater, the plausibility of the threat decreases because Congress can always repeal, amend, or suspend GRH. Professor Stith concludes that GRH is a constitutionally permissible way to constrain deficit growth, but it is neither a fundamental reordering of our fiscal processes nor a "solution" to the persistent deficit problem.
\end{abstract}

\section{INTRODUCTION: The Constitutional AMBITION OF Gramm- RUDMAN-HOLLINGS}

In 1985 there was a federal "budget crisis," widely recognized by members of Congress from both sides of the aisle, ${ }^{1}$ scholarly commenta-

$\dagger$ Associate Professor of Law, Yale Law School. B.A. 1973, Dartmouth College; M.P.P., 1977; J.D., 1977, Harvard Univcrsity. I am grateful for the comments on earlier drafts of this Article made by Joseph White, of the Brookings Institution, and Timothy A. Muris, formerly of OMB and now of George Mason University, neither of whom bears any responsibility for the final product. I thank my colleagues in the Yale Law School Faculty Workshop for their comments, advice, questions, and encouragement. Joseph Gibson, Bradford Mank, Michal Tingle, and David Wrinn provided valuable research assistance.

1. See, e.g., S. REP. No. 144, 99th Cong., 1st Sess. 27-30, reprinted in 1985 U.S. CodE CoNG. \& Admin. News 979, 985-88 (views of Sen. Armstrong (R.-Colo.)); 131 Cong. Rec. S12,088 (daily ed. Sept. 25, 1985) (statement of Sen. Symms (R-Ida.) in support of the Gramm Rudman Hollings Act (GRH): "There is one word in the bill's title that catches the eye-'emergency.' I believe that many of my colleagues share my view that this Nation is sliding toward a precipice, and that this spending gluttony, if we do not reverse it, is going to mean our ruination."); Dixon, The Case for the Line-Item Veto, 1 Notre Dame J.L., Ethics \& Pub. Pol'y 207 (1985) (views of Sen. Dixon (D.III.)); 131 Cong. Rec. 517, $443-44$ (daily ed. Dec. 11, 1985) (Sen. Kennedy (D-Mass.) voting for GRH). 
tors, ${ }^{2}$ and political observers. ${ }^{3}$ Federal spending had grown during the 1970 s and 1980 s more rapidly than in any equivalent peacetime period. This led, especially after 1980, to a precipitous rise in the federal budget deficit. ${ }^{4}$ By 1985 , the federal budget deficit exceeded $\$ 200$ billion; ${ }^{5}$ fifteen years before, the entire federal budget was $\$ 200$ billion. ${ }^{6}$ While federal revenues totalled less than nineteen percent of America's gross national product ("GNP"), the federal government spent twenty-four percent of GNP, the highest peacetime level in our history. ${ }^{7}$ Financing of the federal debt consumed over three percent of the Nation's economic output. ${ }^{8}$ Between 1979 and 1985, the total federal debt-the cumulative outstanding federal deficits of all previous years-more than doubled. ${ }^{9}$ Yet Congress and the President were unable to agree on either tax increases or spending cuts to halt, much less reverse, the trend of deficit growth.

Finally, in late 1985, Congress passed legislation popularly known as the Gramm-Rudman-Hollings Act ("GRH") in an effort to stem the federal debt. ${ }^{10}$ GRH established new procedures which, if adhered to, would eliminate the federal budget deficit by $1991 .^{11}$ The legislation received wide support $\mathrm{m}$ both Houses of Congress ${ }^{12}$ and was hailed by the President as "an important step toward putting our fiscal house in order." 13 Some supported passage of GRH as a temporary method of restraining federal deficits. ${ }^{14} \mathrm{GRH}$ is especially important, however,

2. See, e.g., A. Schick, Crisis in the Budget Process (1985); Elliott, Constitutional Conventions and the Deficit, 1985 DUKE L.J. 1077, 1097-98.

3. See, e.g., N.Y. Times, Dec. 5, 1985, at B26, col. 2; id., Oct. 20, 1985, § 4, at 20, col. 1. See generally Control of Federal Spending, 35 Proc. ACAd. Pol. SCI. No. 4 (1985).

4. See Office of Management and Budget, Executive Office of the President, Budget of THE United States Government FisCal Year 1989 Historical Tables, Table 1.1 (1988) ("Summary of Receipts, Outlays, and Surpluses or Deficits: 1934-1993") [hereinafter Budget OF THE UNITED STATES GOVERNMENT FY 1989].

5. See id. (FY 1985 deficit was $\$ 212.3$ billion).

6. Id. (total outlays in FY 1970 were $\$ 196$ billion). These numbers are not adjusted for inflation.

7. Id. Historical Tables, Table 1.2 ("Summary of Receipts, Outlays, and Surpluses or DeficitsAs Percentages of GNP: 1934-1993").

8. Id., Table 16.2 ("Federal Transactions in the National Income and Product Accounts As Percentages of GNP for Federal Fiscal Years: 1977-89," showing net interest payments of over 3\% for FY 1985; average for FY 1950 - FY 1980 was less than 1.5\%); see also id. Special Analyses B-7.

9. Id. Historical Tables, Table 7.1 ("Federal Debt at the End of the Year: 1940-1993").

10. The Balanced Budget and Emergency Deficit Control Act of 1985, Pub. L. No. 99-177, 99 Stat. 1037 (codified as amended in scattered sections of 2, 31 \& 42 U.S.C.) [hereinaftcr GRH 1985]. GRH was an amendment to an urgent supplemental appropriations bill, H.R.J. Res. 372, 99th Cong., 1st Sess. (1985), which also increased the statutory limit on the public debt, amending 31 U.S.C. § 3101(b) (1982); see also 41 Cong. Q. Almanac 459-68 (1985).

11. See GRH 1985, supra note 10, § 201(7), 2 U.S.C. § 622(7) (Supp. IV 1986).

12. The House vote was 271 for, 154 against, 9 not voting. 131 CoNG. REc. H11,903-04 (daily ed. Dec. 12, 1985). In the Senate, the vote was 61 for, 31 against, 2 paired, 6 not voting. Id. at S17,443-44 (daily ed. Dec. 11, 1985).

13. 41 Cong. Q. Almanac 36-D (1985) (President's Signing Statement, Dec. 12, 1985).

14. See Initial Sequestration Report for Fiscal Year 1987: Hearing Before the Temporary Joint 
because it did not purport merely to effect a marginal reduction in spending. Rather, it sought to establish a new regime to govern the federal budget process, a regime that would guarantee spending and deficit reduction.

Before GRH, the legislature proved unable to cut total spending, to reduce the deficit, or to resist political pressure for inore government programs. GRH sought to change all that by requiring spending reduction even if the President and Congress could not agree on a deficit-reducing budget: if they failed to enact a budget that lowered the deficit to a prescribed maximum, then GRH would impose automatic spending cuts, whicl it terms "sequestration."15 By establishing binding deficit limitations enforced outside of the legislative budget process, GRH's sponsors sought to rewrite the fundamental rules governing fiscal policymaking in the United States-to amend our implicit "fiscal constitution,"16 which for over two centuries had permitted prevailing legislative majorities to spend without limitation. ${ }^{17}$ GRH thus was a major achievement for President Reagan and others whose grander ambition was to establish a new constitutional order that reduced the share of the Nation's resources claimed by the federal government. ${ }^{18}$

The original version of GRH gave the Comptroller General, head of

Committee on Deficit Reduction, 99th Cong., 2d Sess. 35-36 (1986) (statement of Sen. J. Danforth explaining why he voted for GRH). It has been estimated that between 1981 and 1985, six pieces of fiscal legislation reduced the potential federal deficit by $\$ 100$ billion from what it otherwise would have been. See Wehr, Budget Lessons of Recess, Missed Deadlines, 44 CONG. Q. WeEKLY REP. 1517 (1986).

15. GRH 1985, supra note 10, $\$ 257(7), 2$ U.S.C. $\$ 907(7)$ (Supp. IV 1986) (amended 1987). Inasmuch as "sequestration" under GRH operates permanently to withdraw previously appropriated funds, see infra note 192, the word may be imsleading because it has connotations of temporary withdrawal or removal, see RANDOM HOUSE DICTIONARY OF THE ENGLISH LANGUAGE 1747 (1987 ed.).

16. See Dam, The American Fiscal Constitution, 44 U. CHI. L. REV. 271 (1977) (describing constitutional and statutory provisions governing fiscal processes that, taken as a whole, constitute the "fiscal constitution").

17. See Fuerbringer, Trepidations on the Budget Process, N.Y. Times, Jan. 9, 1986, at A20, col. 6 (GRH is "the most radieal change in the way Congress and the executive branch deal with the basic problems of the American economy in the history of the Republic.").

18. According to David Stockman, Director of OMB during President Reagan's first term, President Reagan supported the tax cut of 1981 in order to force a reduction in federal spending. Greider, The Education of David Stockman, ATLANTIC MonTHLY, Dec. 1981, at 27. When that strategy failed, President Reagan supported GRH as a provisional step toward reducing federal spending and rejected any inerease in taxes to reduce the deficit. In his Economic Report for FY 1987, the President stated:

The key to resolving the Federal budget deficit is to restrain unneeded spending. Spending, not the deficit, is the true indicator of the cost of government, because it measures the total economic resources diverted from the private sector. ...

$I$ applaud and support the newly enacted [GRH] as a way to work with the Congress to reduce Federal spending and the deficit. ...

[GRH] accomplishes only part of our long-term objective of Federal fiscal responsibility.

Economic Report of the President, 22 WeEkLY COMP. Pres. Doc. 158, 160-61 (Feb. 10, 1986). The 
the General Accounting Office, ${ }^{19}$ final responsibility for enforcing GRH's deficit limitation. ${ }^{20}$ This provision, however, was held unconstitutional in Bowsher v. Synar, ${ }^{21}$ decided in the summer of 1986; the Supreine Court held that the Comptroller General's role under the Act violated separation-of-powers principles. In the Court's view, the Comptroller General is constitutionally prohibited froin executing the laws because he is a "legislative officer.",22

Most political and legal commentary pronounced GRH dead. ${ }^{23}$ In the fall of 1987, however, Congress and the President amended GRH to restore the automatic sequestration process. ${ }^{24}$ They elinninated the constitutional defect identified by the Supreine Court by giving final responsibility for implementing sequestration to the Office of Managennent and Budget (OMB) in the Executive Office of the President. ${ }^{25}$ Thus, GRH remains the law, and understanding both its ambitions and its linnitations is essential to understanding the place of the budget in our constitutional system.

GRH alters the legal frainework and the legislative and adininistrative practices of federal budgeting in several significant ways. First, GRH makes the annual budget deficit, which is merely an estinnate of net federal cash outlays during the fiscal year, the touchstone of the legislative budget process. ${ }^{26}$ Second, and related to the first, sequestration makes the timing of outlays a critical concern in the adininistration of appropriations. ${ }^{27}$ Third, GRH creates an incentive for Congress to specify appropriations in greater detail, thereby restricting executive discretion over the allocation of appropriations. ${ }^{28}$

Yet GRH does not fundamentally redesign our fiscal processes. It does not directly address the governinent's growing reliance upon "entitlements" and other forms of spending that are not subject to annual

President went on to call for a balanced budget amendment and line-item veto authority. Id.; see also infra note 190.

19. See 31 U.S.C. \& 702(b) (1982).

20. GRH 1985, supra note 10, § 251(b), 2 U.S.C. § 901(b) (Supp. IV 1986) (amended 1987).

21. 106 S. Ct. 3181 (1986).

22. Id. at 3186-92.

23. See, eg., Broder, Last Rites for G-R-H, Wash. Post, Nov. 23, 1986, at D7, eol. 1; N.Y. Times, Oct. 14 1986, at A34, col. 1; id., Aug. 7, 1986, at A26, col. 1; Schiller, Gramm-Rudman: Toothless Dragon, id., Feb. 6, 1986, at A23, col. 3; Richards, The Gutting of Gramm-Rudman: Implications for Bureaucrats, Budgets, and the Balance of Power, 22 NEw ENG. L. REv. 1 (1987).

24. The Balanced Budget and Emergency Deficit Control Reaffirmation Act of 1987, Pub. L. No. 100-119, 1987 U.S. CODE CONG. \& ADMIN. NEWS (101 Stat.) 754 (to be codified in scattered sections of 2 \& 42 U.S.C.) [hereinafter GRH 1987].

25. Id. $\S 102($ a), 2 U.S.C.A. $\S 901$ (a) (West Supp. 1987) (amending GRH 1985, supra note 10, § 251(a), 2 U.S.C. § 901(a) (Supp. IV 1986)).

26. See infra text accompanying notes 247-73.

27. See infra text accompanying notes $274-94$.

28. See infra text accompanying notes 295-327. 
appropriations control. ${ }^{29}$ More importantly, GRH does not remove spending decisions from the legislative arena. Thus, although GRH alters some rules of our fiscal constitution to make it politically easier to achieve deficit reduction, ${ }^{30}$ the statute does not diminish Congress' constitutional power to spend. ${ }^{31}$

In order to appreciate both GRH's ambitions and its accomphishments, it is necessary to understand the federal budget process as it evolved prior to 1985 . The following section, Part I, briefly explores the history of the legal framework governing the enactment and administration of appropriations legislation. Parts II and III examme in detail both GRH's provisions and their effects on traditional budget processes. Finally, Part IV explains that GRH does not and cannot take politics out of the spending process, and hence it cannot reduce the deficit without a sustained political consensus to achieve this end.

\section{I}

\section{The Constitutional Budget Process Before Gramm- RUDMAN-HOLLINGS}

The Constitution places the fiscal power of the federal government in the hands of tlie legislative branch. Congress (with the President in his legislative capacity) has the power to $\operatorname{tax}^{32}$ and to borrow on the credit of the Uinited States. ${ }^{33}$ Congress also has the power to spend, as "necessary and proper"34 to carry out its enuinerated powers and its power to "provide for the common Defence and general Welfare."35 However, one of the most important fiscal provisions in the Constitution is not so inuch a grant of power as a limitation on the exercise of power: the appropriations clause ${ }^{36}$ prohibits the executive branch of the federal governinent froin spending public funds except pursuant to "Appropriations made by Law."

Under the appropriations clause, the legislative branch is politically and constitutionally responsible for federal spending and, lence, for the federal deficit. ${ }^{37}$ Because of the Constitution's requirement of congressional authorization for all federal spending, appropriations legislation

29. See infra text accompanying notes 339-51.

30. See infra text accompanying notes $188-91$ \& 387-92.

31. See infra text accompanying notes 362-85.

32. U.S. ConsT. art. I, $\S 8$, cl. 1 .

33. Id. art. I, $\S 8$, cl. 2 .

34. Id. art. I, $\S 8, \mathrm{cl} .18$; McCulloch v. Maryland, 17 U.S. (4 Wheat.) 316, 419-21 (1819).

35. U.S. CoNST. art. I, $\S 8$, cl. 1 .

36. Id. art. I, $\S 9, \mathrm{cl} .7$ ("No Money shall be drawn from the Treasury, but in Consequence of Appropriations made by Law.").

37. In another article, I develop a theory explaining why the requirement of legislative appropriations is at the foundation of our constitutional order. See Stith, Congress' Power of the Purse, 97 Yale L.J. (forthcoming, May 1988). 
has been a major preoccupation of both Congress and the President throughout the Nation's history. However, the appropriations requirement is neither self-defining nor self-executing. ${ }^{38}$ Beyond requiring legislative permission for federal expenditures, the Constitution is silent as to what form appropriations should take.

The procedures and practices of the modern legislative budget process evolved slowly over 200 years. As Congress and the President constrned and apphed the Constitution's provisions, they, in effect, crafted our implicit fiscal constitution. This Part explains the evolution of the constitutional budget process prior to GRH, primarily in three important areas in which our written Constitution is silent: (a) the process of preparing and enacting a federal budget; (b) the relationship between a legislative grant of spending authority and actual withdrawal of funds from the Treasury; and (c) the specificity of appropriations measures.

\section{A. The Federal Budget}

The concept of "Appropriations" in article $I$, section 9, clause 7 of the Constitution relates only to legislative approval for spending, not to the source of the funds that will be spent. ${ }^{39}$ The Constitution does not limit annual federal spending to available tax revenues. Moreover, while the Constitution empowers each House to "determine the Rules of its Proceedings, ${ }^{140}$ neither House has required that spending bills be limited by tax ineasures, ${ }^{41}$ nor even that revenue proposals and spending proposals be considered sinultaneously in a single bill or set of bills. ${ }^{42}$ The

38. Harrington v. Bush, 553 F.2d 190, 194 (D.C. Cir. 1977); see also Reeside v. Walker, 52 U.S. 272, 290-91 (1850); Stitzel-Weller Distillery v. Wickard, 118 F.2d 19, 24 (D.C. Cir. 1941); 2 J. STORY, COMMENTARIES ON THE CONSTITUTION OF THE UNITED STATES $\$ \S 1346-1349$ (5th ed. 1891).

39. Moreover, the Constitution explicitly regulates only the disbursement of public monies, or what Congress has termed "outlays." See infra note 70 and accompanying text. The narrow focus of the appropriations clause may explain why, despite reformers' grander ambitions, the budget has never purported to measure the federal government's net addition to or subtraction from the real wealth of the nation; nor has it purported to measure the relative costs and benefits of expenditure programs.

Some appropriations bills encompass a small portion of revenues by treating them as "negative" expenditures. In general, however, revenue legislation is separate from appropriations legislation in the budget process, though in recent years tax measures have been combined with spending measures in one omnibus bill at the end of the process. See BUDGET OF THE UNITED STATES GOVERNMENT FY 1989, supra note 4, at Part 6d and 6e; see also infra text accompanying notes 150-57. This Article, like GRH itself, focuses on the expenditure side of the budget process.

40. U.S. CoNST. art. I, $\S 5$, cl. 2.

41. Before GRH, Congress had resolved to reduce the deficit, see, e.g., Deficit Reduction Act of 1984, Pub. L. No. 98-369, $\S 2101-2102$, 98 Stat. 494, 1057-58, but it had never before sought to make deficit reduction a statutory requirement, enforceable by non-legislative mechanisms. The 1984 deficit elimination goal was iguored.

42. The Legislative Reorganization Act of 1946, ch. 753, \& 138, 60 Stat. 812, 832, did call for Congress to adopt an annual "legislative budget," but the call was ignored and the legislation repealed in 1970, § 242(b), 84 Stat. 1172. 
procedural and substantive separation of revenue and spending legislation predates the founding of the United States; it was the practice in England and the colonies. ${ }^{43}$

Throughout most of American history, the federal budget process has been fragmented. ${ }^{44}$ Congress has not sought to adopt, ex ante, a comprehensive federal "budget"; rather, it has considered both spending and revenue legislation on an ad hoc basis throughout each session of Congress. Although most operating expenses of the federal government were appropriated annually (following the colonial practice), it was not until 1842 that Congress adopted the concept of a "fiscal year," and began to establish a timetable for consideration of spending legislation. ${ }^{45}$

Moreover, before the Civil War, each House gave one legislative coinmittee responsibility for reporting all fiscal legislation: the House Ways and Means Committee, and the Senate Finance Committee. ${ }^{46}$ After the Civil War, first the House and then the Senate established separate appropriations committees. ${ }^{47}$

This uncoordinated budget process was adequate for the needs of the 19th century; the federal budget usually remained in surplus (except during wartine) as tariff revenues outpaced spending. ${ }^{48}$ However, the expansion of the federal government's activities in the early 20th century made reform of the budget process necessary. With the prohferation of spending prograins, accomparied by new sources of revenue under the sixteenth amendment, ${ }^{49}$ there were calls for a more unified and compre-

43. See V. Browne, The Control of the Public Budget 11-17 (1949); L. Labaree, ROYAL GOVERNMENT IN AMERICA 269-339 (1930).

44. The most illuminating history of congressional efforts to establish effective control over federal spending is L. WILMERdiNg, THE SpENDING Power (1943). A brief but comprehensive discussion of conflicts between the President and Congress in this area is L. FISHER, PresidenTIAL SPENDING POWER (1975).

45. Act of Aug. 26, 1842, ch. 207, 5 Stat. 536 (defining the fiscal year from July 1 to June 30), amended by 31 U.S.C. $\S 1102$ (1982) (defining the fiscal year from October 1 to September 30, beginning in 1975).

46. See L. Wilmerding, supra note 44, at 39 (House Ways and Means established as temporary committee in 1796; Senate Finance Committee established threc years later). The Ways and Means Committee was established as a standing committee im 1802; the Senate Committee on Finance became a standing committee in 1816. See House COMM. ON THE Budget, 100TH CONG., IST Sess., The Whole and the Parts: Piecemeal and Integrated Approaches to Congressional Budgeting 3-11 (Comm. Print 1987) (report prepared for Task Force on the Budget Process by A. Schick) [hereinafter ScHICK REPORT].

47. SCHICK REPORT, supra note 46 , at 4 . The appropriations committees were stripped of some of their authority over spending in the late 19th century and did not get it back until the early 1920s. See L. WILMERDiNG, supra note 44, at 143-44, 176-77.

48. See U.S. Dept. of Cominerce, Bureau of the Census, Historical Statistics of the United States Colonial Times to 19701104 (1976) ("Summary of Federal Government Finances Administrative Budget: 1789 to 1939 ").

49. U.S. CoNsT. amend. XVI. Prior to the passage of the sixteenth amendment, the Supreine Court had invalidated Congress' attempt to mipose an income tax. Pollock v. Farmers' Loan \& Trust Co., 158 U.S. 601 (1895). 
hensive approach to the federal budget. ${ }^{50}$ The crushing federal deficit that resulted from the First World War appears to have been the principal impetus for enactment of the Budget and Accounting Act of 1921..$^{51}$ Prior to the 1921 legislation, few presidents or Treasury secretaries formally participated in budget preparation; executive agencies and departments submitted their budget requests directly to Congress. ${ }^{52}$ In contrast, the Budget and Accounting Act made the President the central player in the budget process by requiring that he submit a proposed budget, including both tax and spending legislation, to Congress each year. $^{53}$ The 1921 law also created the Bureau of the Budget within the executive branch, ${ }^{54}$ thus granting the President a major source of expertise and power in budget preparation and negotiation. ${ }^{55}$ Of course, the budget subimitted by the President each year is, constitutionally, simply a proposed bill. Congress always has retained the power to accept all, some, or none of the President's proposed budget. ${ }^{56}$

The Budget and Accounting Act of 1921 constituted a significant addition to the rules governing our fiscal processes-our fiscal constitution. It gave the executive branch responsibility for defining the overall structure and most of the details of the federal budget. Although Congress simultaneously consohidated its legislative appropriations process, ${ }^{57}$ it maintained the separation between spending and revenue legislation, and it did not attempt to adopt a unified budget comparable to the President's. Not until the Congressional Budget and Impoundment Control Act of 1974, ${ }^{58}$ examined in the final Section of this Part, did Congress

50. See, e.g., President's Commission on Economy and Efficiency, The Need for a National Budget, H.R. Doc. No. 854, 62d Cong., 2d Sess. $59-78$ (1912) [hereinafter TAFT COMmission]; see also L. FisHER, supra note 44, at 29-35.

51. Ch. 18, 42 Stat. 20 (1921) (codified as amended in scattered sections of 31 U.S.C.).

52. See TAFt Commission, supra note 50, at 23-58 (describing the budget process in the 19th and early 20th century); see also V. BROWNE, supra note 43, at 83-88; L. WILMERDING, supra note 44 , at $180-95$.

53. The Budget and Accounting Act of 1921, ch. 18, $\S 301,42$ Stat. 23 (codified at 31 U.S.C. $\S 1105$ (1982)).

54. Id. ch. $18, \S 207,42$ Stat. 22 (codified at 31 U.S.C. $\S 501$ (1982)). Originally, the Bureau of the Budget was part of the Department of the Treasury; subsequently, it was transferred to the Executive Office of the President. See Exec. Order No. 8248, 3 C.F.R. 576 (1938-1943); infra note 118 and accompanying text.

55. The law also created the General Accounting Office ("GAO"), headed by a Comptroller General removable only by Congress, which increased Congress' ability to ensure compliance with its appropriations legislation. Id. ch. $18, \S 302,42$ Stat. 20 (codified at 31 U.S.C. $\S 703$ (1982)).

56. The United States has never had a pure executive budget, such as exists today in France. The French Parliament is given 70 days to review the President's budget proposal and may neither increase spending nor decrease revenues; if Parliament does not act, the budget becomes law by ordinance. ConST. art. 47, I 3 (France); see Malbin, Plus Ça Change, 16 NAT’L J. 729 (1984).

57. See SCHICK REPORT, supra note 46 , at 9.

58. Pub. L. No. 93-344, 88 Stat. 297 (codified as amended in scattered sections of 1,2 \& 31 U.S.C.). Title X of the statute, $\S \S 1001-1017,88$ Stat. $297,332-37$ (codified as amended at 2 U.S.C. $\S \S 681-688$ (1982)), incorporates the Impoundment Control Act; the other titles govern the budget 
seek budgetary responsibility and capability commensurate with that of the President.

\section{B. The Relationship Between Withdrawal from the Treasury and Legislated Spending Authority}

The appropriations clause requires legislative approval only for cash "drawn" from the Treasury, ${ }^{59}$ or cash "outlays" to use the modern terminology. Congress has failed to mamtain control over federal spendimg in part because of this constitutional focus on withdrawal. The time for effective control over expenditures is not when money is drawn from the Treasury, but rather when Congress grants federal agencies the authority to obligate future withdrawals. Throughout our history, Congress has exercised less detailed annual control of this "obligational authority"60 than it has of outlay authority.

\section{Appropriations: The Distinction Between Outlays and Budget Authority}

In the early years of the Republic, Congress conceived of appropriations as pliysical sums of cash to be allocated to one object or another. ${ }^{61}$ The "surplus fund" legislation of $1795^{62}$ required that momies appropriated for a particular purpose be paid out of the appropriations account within two years or otherwise be returned to a fund (the "surplus fund") in the Treasury. As long as the amount an agency paid out did not exceed the amount in its appropriation account, the agency was deemed to have acted witlim its appropriation. ${ }^{63}$

process and budget legislation. This Article will refer to the 1974 legislation as the Congressional Budget Act of 1974, unless the reference includes Title X. See infra text accompanying notes 14077.

59. "No Money shall be drawn from the Treasury . . . ." U.S. CoNST. art. I, $\S 9$, cl. 7 (emphasis added).

60. "Obligational authority" is defined as "[t]he sum of (a) budget authority provided for a given fiscal year, (b) balances of amounts brought forward from prior years that remain available for obligation, and (c) amounts authorized to be credited to a specific fund or account during that year, including transfers between funds or accounts." GENERAL AccountiNg OFFICE, A GLOSSARY OF TERMS USED IN THE Federal Budget Process 67-68 (3d ed. 1981) [hereinafter Glossary]; see also General Accounting OfFice, Principles of Federal Appropriations Law 6-2 to -5 (1982) [hereinafter PRINCIPLES].

61. Thus, Alexander Hamilton argued that it was inportant for Congress to lunit the duration of an appropriation because to "leave them indefinite, as to time," might "tie up, unnecessarily, a portion of the public funds, which may, ultimately, not be wanted at all for the purpose of the original appropriation." L. W1LMERDING, supra note 44, at $32 \mathrm{n} .21$; see also id. at 67 (statement of John Randolph: "We have seen that so long as there is money in the Treasury, there is no defence against its expenditure.") (quoting 15 ANNALS OF CONG. 1063 (1806)).

62. Act of Mar. 3, 1795, ch. $45, \S 16,1$ Stat. 433,437 (current version at 31 U.S.C. $\$ 1502$ (a) (1982)).

63. See generally L. WILMERdING, supra note 44, at 20-30. Apparently, during most of the 19tl ccntury, time limitations on expenditures applied only to appropriated balances reinaining 
It soon became apparent to Congress and the President that this conception of appropriations was inadequate because it did not control federal obligations prior to outlay. ${ }^{64}$ In the early 19th century, Congress passed a number of laws intended to achieve greater legislative control over obligational authority rather than simply outlay authority. ${ }^{65}$ Nonetheless, not until 1870 did Congress enact a general prohibition against obhigating federal funds in excess of appropriations. ${ }^{66}$ This prohibition was carried forward in the Anti-Deficiency Act of $1905 .{ }^{67}$ The require1nent that obligations not exceed appropriations is an inportant ineans of legislative control, for it indicates that appropriations limit the executive's authority to obhgate, and not simply his authority to make cash withdrawals. After World War II, Congress enacted legislation inaking exphicit that annual appropriations inust be obligated, but not necessarily expended, within one year. ${ }^{68}$

In conteinporary budget terminology, the term "budget authority" includes all spending authority granted to an agency; 69 "outlays" are the payments that result once budget authority becomes obligated. ${ }^{70}$ The time limitations on appropriations fix the period in which obligation inay occur, not the period for making outlays. ${ }^{71}$ Thus, the actual outlays of any current fiscal year are not equal to the ainount of budgetary resources appropriated for that year because some budget authority will not be spent until future years. Conversely, soine of the current fiscal

within the Treasury. The Treasury's function was mimisterial-forwarding appropriations as requested. See id. at $30-31$.

64. See L. FiSHER, supra note 44, at 229-30. See also L. WILMERDING, supra note 44, at 77-98.

65. See, e.g., Act of May 1, 1820, ch. 52, § 6, 3 Stat. 567, 568 (prohibiting military departments from obhigating federal momies in advance of appropriations, unless legislatively authorized to do so).

66. Act of July 12,1870 , ch. $251, \S 7,16$ Stat. 230,251 provided:

[I] $t$ shall not be lawful for any department of the government to expend in any one fiscal year any sum in excess of appropriations made by Congress for that fiscal ycar, or to involve the government in any contract for the future payment of money in excess of such appropriations.

67. Act of Mar. 3, 1905, ch. 1484, §3679, 33 Stat. 1214, 1257-58, amended by General Appropriation Act of 1951, ch. 896, § 1211, 64 Stat. 595, 765-68 (1950), amended by Congressional Budget Act of 1974, Pub. L. No. 93-344, § 1002, 88 Stat. 297, 332 (codified at 31 U.S.C. $\$ 1341$ (1982)).

68. Surplus Fund-Certified Claims Act of 1949, ch. 299, 63 Stat. 407 (codified at 31 U.S.C. § 1502(a) (1982)).

69. The Congressional Budget Act of 1974, as amended, defines "budget authority" as "authority provided by law to enter into obligations which will result in immediate or future outlays involving Government funds or to collect offsetting receipts," excluding authority to insure or guarantee loans. 2 U.S.C. \$ 622(2) (Supp. IV 1986); see also infra note 238 (defining budgetary "resources").

70. "Outlays" are defined as "expenditures and net lending of funds under budget authority during [any fiscal] year." 2 U.S.C. § 622(1) (1982).

71. 31 U.S.C. $\S 1502(a)(1982)$. Obligated budget authority remains available beyond the appropriation act's time limitation ouly to hquidate properly made obligations. Id. Unobligated balances expire at the end of the fiscal year, or other time period stated in the statute, and are no longer available for obligation or outlay. 31 U.S.C. $\S 1552(a)(2)(1982)$. 
year's outlays result from budget authority appropriated (and possibly even obligated) in previous years but not spent until the current year. ${ }^{72}$

\section{Budget Authority Outside of Annual "Appropriations" Acts}

Not all appropriations are provided by annual appropriations acts. Some appropriations are multiyear; that is, they are available for obligation for more than one year. ${ }^{73}$ Still other appropriations are permanent; that is, a statute automatically provides new budget authority each year ${ }^{74}$ until Congress repeals the permanent appropriation. ${ }^{75}$ Sometimes, supplemental appropriations are enacted to augment the funds already provided to an agency in its regular annual appropriations. ${ }^{76}$ Finally, if Congress fails to enact annual appropriations by the beginning of the new fiscal year, it typically enacts a joint resolution (a "continumg resolution") that teinporarily continues funding, usually at the previously established level. ${ }^{77}$

Congress also provides budget authority completely outside of appropriations legislation and thus outside the purview of each House's

72. Thus, at the beginning of each fiscal year there are two types of outstanding budget authority: (1) "obligated"-budget authority already obligated (for instance, by contract or by an order for goods), but not yet an outlay; and (2) "unobligated"-_budget authority neither obligated nor spent. See Budget of THE UNITEd STATES GoverNmeNT FY 1989, supra note 4, at 6a-1 to -3; Glossary, supra note 60, at 40; PRINCIPLES, supra note 60 , at $4-33$ to -39 .

73. See, e.g., Military Construction Appropriation Act of 1986, Pub. L. No. 99-173, 1985 U.S. CoDE CoNG. \& ADMIN. NEwS (99 Stat.) 1024 ( $\$ 1,602,982,000$ appropriation for military construction in the Army "to remain available until September 30, 1990").

74. See, e.g., 31 U.S.C. $\S 3123$ (1982) (permanent appropriation of interest on the national debt).

75. Of course, Congress has the power to repeal "permanent" appropriations. In addition, Congress may withdraw appropriated budget authority that has not been obligated. See, e.g., 31 U.S.C. $\S 1555$ (a) (1982) (unobligated balance shall be withdrawn when purposes of appropriation have been carried out or when no disbursement is made for two consecutive years). A recission of appropriations pursuant to the Impoundment Control Act of 1974 is, in effect, a withdrawal of appropriations. 2 U.S.C. $\S 683$ (1982 \& Supp. V 1987); see also H.R. REP. No. 658, 93d Cong., 1st Sess. 52 (1973), reprinted in 1974 U.S. CODE CONG. \& ADMIN. NEwS 3462, 3497 (impoundment includes "termination of authorized projects or activities for which appropriations have been made").

76. A supplemental appropriation is "[a]n act appropriating funds in addition to those in an annual appropriation act." GLOSSARY, supra note 60, at 79; see also PRINCIPLES, supra note 60, at 5-104 to -106 .

77. A "continuing resolution" has the same force and effect as any other public law. See Oklahoma v. Weinberger, 360 F. Supp. 724, 726 (W.D. Okla. 1973). Generally, a continuing resolution appropriates at a certain rate rather than in a definite amount. Often the rate is the lesser of the "current" (previous year's) rate or the rate in an annual appropriation that has passed at least one House but has not been enacted into law. See, e.g., UAW v. Donovan, 746 F.2d 855, 858 (D.C. Cir. 1984) cert. denied, 474 U.S. 825 (1985) (discussed infra note 123). A 1981 study showed that $85 \%$ of annual appropriations bills in the previous 20 years were enacted after the beginning of the new fiscal year, necessitating continuing resolutions to avoid a lapse of funding authority. See General accounting Office, Funding Gaps Jeopardize federal Government OPERATIONS 4-9 (1981). 
appropriations committee. ${ }^{78}$ These nonappropriation forms of obligational authority — called "backdoor spending" - ultimately require withdrawal from the Treasury as do conventional spending bills (appropriations acts). However, most forms of backdoor spending legislation only authorize agencies to make obligations for future outlays, not subsequent payment on obligations; consequently, Congress must enact "liquidating" appropriations to permit cash outlays for these obligations as they become due.

There are three major types of backdoor spending authority. The oldest form of nonappropriation funding is "contract authority." 80 Contract authority is pure obhigational authority; it does not include authority to make outlays. Congress grants contract authority in advance of appropriations and subsequently enacts an "appropriations act" to allow payment of the obligations. ${ }^{81}$ Even after Congress began routinely making appropriations in terms of obligational authority, it continued-and continues to this day-to fund some agencies and projects through contract authority. ${ }^{82}$ Contract authority has been called a "delusion and a snare."83 It is particularly subject to abuse because, although it does not involve direct permission for outlay of money, it gives an agency constitutional authority to obhigate future payment of government funds just as surely as does authority provided by appropriations acts. ${ }^{84}$ When Congress subsequently gives an agency authority to make actual payments due on contract obligations, this hiquidating appropriation provides no additional budget authority.

78. Such legislation is reported by the committees (sometimes referred to as authorizing committees) with substantive jurisdiction; the "authorizing" legislation itself grants budget authority. See generally SCHICK REPORT, supra note 46, at 12, 17.

79. See S. REP. No. 579, 93rd Cong., 1st Sess. 8-10 (1973); H.R. REP. No. 658, 93rd Cong., 1st Sess. $22-23$ (1973), reprinted in 1974 U.S. CODE CONG. \& ADMIN. News 3462, 3469-70; GLOSSARY, supra note 60 , at 40 (backdoor authority is "[b]udget authority provided in legislation outside the normal ... appropriations process").

80. Contract authority is "[s]tatutory authority that permits obligations to be incurred in advance of appropriations ...." GLOSSARY, supra note 60 , at 42.

81. See Train v. City of New York, 420 U.S. 35, 39 n.2 (1975); National Ass'n of Regional Councils v. Costle, 564 F.2d 583, 586 (D.C. Cir. 1977); State Highway Comm'n v. Volpe, 479 F.2d 1099, 1107-08 (8th Cir. 1973). Sometimes Congress enacts a permanent appropriation for liquidation of contract authority. See, e.g., 31 U.S.C. $\$ 1305$ (1982 \& Supp. III 1985) ("miscellaneous permanent appropriations").

82. One major reason for the contmued use of contract authority has been that it diffuses power over spending beyond the appropriations committees of each House. See A. ScHick, CONGRESS AND MONEY 215-17 (1986); Haas, Unauthorized Action, 20 NAT'L J. 17 (1988).

83. H.R. REP. No. 216, 85th Cong., 1st Sess. 5 (1957).

84. See Costle, 564 F.2d at 586-88. The so-called "Second Hoover Commission" recommended the adoption of an accrued expenditure budget, whereby appropriations would be equal to accrued outlays during the coming year, with no provision of contract authority or other obligational authority more than one year in advance of actual expenditure. See CoMmission on ORGANIZATION OF THE EXECUTIVE BRANCH OF THE GOVERNMENT, BUDGET AND ACCOUNTING, A REPORT TO THE CONGRESS 22-25 (1955). 
A second form of nonappropriation budget authority is authority to borrow from the public or the Treasury and spend the proceeds without further legislative approval. ${ }^{85}$ Borrowing 'authority is fiscally indistinguishable from general deficit financing of federal expenditures, but there is no "appropriation" until the borrowed funds are paid back, with interest. Like contract authority, borrowing authority has been used since the earliest days of the nation. ${ }^{86}$

"Entitlement authority" is a third form of nonappropriation spending authority. ${ }^{87}$ Although entitlement authority is also of old vintage, it only recently has become, in terms of its percentage of the budget, the most significant form of nonappropriation funding. Entitlements, such as formula grant programs for individuals and other entities, usually are permanently appropriated ${ }^{88}$ and may be funded either from trust fund receipts (used in the various programs of the Social Security Admimistration $)^{89}$ or general revenues. ${ }^{90}$ Because outlays for most entitlements occur automatically, ${ }^{91}$ they are not even nominally subject to annual appropriations control..$^{92}$ For most entitlements, the amounts shown in each year's budget documents are simply estimates based on the projected number of beneficiaries and the statutory benefit formula. ${ }^{93}$

85. See A. SCH1CK, supra note 82 , at 215 . Borrowing authority is "[s]tatutory authority that permits a Federal agency to incur obligations and to make payments for specified purposes out of borrowed monies." Glossary, supra note 60, at 42. Section 401(c)(2) of the Congressional Budget Act of 1974, as amended, includes borrowing autlority as one form of "spending" authority, 2 U.S.C. $\S 651(c)$ (2) (Supp. IV 1986). Borrowing authority is "autliority (whetler temporary or permanent) ... to mcur indebtedness ... for the repayment of whicli the United States is liable, the budget authority for which is not provided in advance by appropriation Acts." Id. $\S 651$ (c)(2)(B).

86. See, e.g., Act of Aug. 4, 1790, ch. 34, \& 2, 1 Stat. 138, 139 (authorizing the President to borrow to pay certain foreign debt); Act of Aug. 7, 1789, ch. 9, § 3, 1 Stat. 53, 54 (authorizing the Secretary of the Treasury to contract to build a highthouse).

87. Entitlements are "[l] egislation that requires the payment of benefits (or entitlements) to any person or unit of government that meets the eligibility requirenents establislied by sucl law." Glossary, supra note 60, at 57; see also Congressional Budget Act of 1974 as amended, $\S 401(\mathrm{c})(2)(C), 2$ U.S.C. $\S 651(\mathrm{c})(2)(C)(1982) ; 2$ U.S.C. § 622(9) (Supp. IV 1986) (labelling the spending autlority described by $\S 401$ (c)(2)(c) "entitlement authority").

88. See House COMm. ON the Budget, 98th Cong., 2D Sess., Review of the Reconciliation Process 49-50 (Comm. Print 1984).

89. See 42 U.S.C. $\S 401$ (1982 \& Supp. III 1985).

90. See, e.g., 7 U.S.C. $\S 612 c$ (Supp. III 1985) (formulaic entitlement to encourage exportation and domestic consumption of agricultural products).

91. Permanent appropriations operate automatically to provide funding eacli year, witlout action by Congress. The major entitlement programs liave permanent appropriations. Examples include social security, 42 U.S.C. $\S \S 401-433$ (1982 \& Supp. IV 1986), and federal retirenent payments, 10 U.S.C. $\S \S 1201,1202,1204,1205,1275,1315,1331$ (1982 \& Supp. IV 1986).

92. Some entitlement programs must be annually funded, including Medicaid, 42 U.S.C. $\S 1396$ (1982 \& Supp. IV 1986), Aid to Families with Dependent Children, 42 U.S.C. $\S 601$ (1982), and various veterans benefits, 38 U.S.C. $\S \S 314,503,521$ (1982 \& Supp. III 1985), but these appropriations are treated as mandatory by Congress, like liquidating appropriations for contract autlority. See Review OF THE RECONCILIATION PROCEss, supra note 88, at 49, 69.

93. See Budget of the UNited StATES GovernMeNT FY 1989, supra note 4, at 2b-16. 
Federal credit guarantees, although not always termed "backdoor" spending, are analytically similar to the three forms of backdoor spending authority described above. ${ }^{94}$ Where Congress grants an agency authority to guarantee a privately obtained loan, budget documents show no "appropriation" of budget authority, even though some portion of such guaranteed loans will default, requiring federal outlays. ${ }^{95}$ The formal "appropriation" does not occur until Congress enacts liquidating appropriations to pay its credit obligations. Thus, like other forms of backdoor spending, loan guarantees represent obligations in advance of both outlay and appropriation.

Congress resorts to backdoor spending mechanisms for various reasons. Contract authority seems especially appropriate for long-term projects where payment will be made over many years. ${ }^{96}$ To the early congresses, which conceived of appropriations as discrete sums of cash, ${ }^{97}$ it appeared wasteful to appropriate fully for a long-term contract prior to the contract's execution. Backdoor spending is also a way for interested constituencies and their supporters in Congress to protect programs from appropriations committees and, often, from any annual legislative review. ${ }^{98}$ For example, when a program is formulated as an "entitlement" and a trust fund is used to fund the program, both the revenue source and the spending authority for the program are procedurally and politically insulated from direct competition with other federal programs. Permanent and autoinatic appropriation for entitlements enhances the security of recipients by shielding this large portion of the budget from the annual appropriations process. Indeed, the very concept of entitlements is fundainentally inconsistent with annual appropriations control. ${ }^{99}$

By the 1970s, inore than fifty percent of all federal spending was in the form of backdoor spending. ${ }^{100}$ Altogether, about seventy percent of outlays each year were said to be "uncontrollable."101 This term is inis-

94. See S. Collender, The Guide to the Federal Budget 166 (1986) (defining loan guarantees); Budget of THE UNITED STATES GOVERNMENT FISCAL YEAR 1989, supra note 4, at $6 \mathrm{e}-9$ to -12 , (discussing nonappropriation budget authority separately from "federal credit activities"); PrINCIPLES, supra note 60, at 14-4 to -5; Haas, Giving Credit Its Due, 19 NAT'L J. 1836 (1987).

95. On the other hand, where Congress grants a federal agency authority to make a direct loan, budget documents treat the full amount of the loan authority as having been "appropriated," even though some portion of the loans (plus interest) will be repaid. See S. Collender, supra notc 94, at 164.

96. E.g., H.R. REP. No. 658, 93rd Cong., 1st Sess. 23 (1973), reprinted in 1974 U.S. CodE CONG. \& ADMIN. NEWS 3462, 3469.

97. See supra note 61 and accompanying text.

98. See A. SCHICK, Congress AND MONEy 215-17 (1980). See generally Haas, supra note 82.

99. See SCHICK REPORT, supra note 46, at 18-19.

100. See L. LeLoup, The Fiscal CoNGress 9 (1980).

101. Id. at 12. Outlays are "relatively uncontrollable" when preexisting statutes, contracts, or 
leading, for it suggests that Congress lacks constitutional power to prevent "uncontrollable" outlays from occurring. For the most part, in fact, Congress can control the "uncontrollable" budget. "Uncontrollable" expenditures result from previously enacted budget authority, including unspent balances, permanent appropriations, and entitlements. Congress has the constitutional power to withdraw budget authority for all of these except contractual obligations, which for the most part are represented by obligated balances of budget authority. ${ }^{102}$ "Uncontrollability" in the budget process means only that outlays will occur unless Congress takes action to prevent them-for instance, by annending entitlement legislation or repeahing a permanent appropriation.

Nonetheless, the concept of uncontrollability is useful because it reminds us that the outlays that occur in each year result from inany years' spending decisions, both in Congress and in adıninistering agencies. As Part IV will show, GRH leaves the uncontrollable federal budget virtually untouched because it exempts entitleinents, unspent balances of budget authority, and liquidating appropriations from mandated spending reductions.

\section{Legislative Specification of the Details of Federal Spending}

The Constitution does not require any particular degree of specificity in appropriations legislation. In the 19th century, Congress tended to provide relatively detailed directions to the executive as to how to spend appropriated sums. In the 20th century, Congress has granted the executive significant leeway to decide how to allocate appropriated sums among various federal programs, projects, and activities. As Part III demonstrates, GRH represents a move back toward a greater congressional role in the allocation of appropriations.

\section{Early Efforts To Assert Legislative Control: "Line Itemization"}

Throughout nnost of the Nation's history, Congress has engaged in detailed "line itemization" of appropriations. ${ }^{103}$ Typically, appropriations bills specified exactly how much money each departınent or program could spend on particular objects or purposes (including such routine items as supplies and personnel). ${ }^{104}$ Congress also enacted

other obligations determine the spending level, see BUDGET OF THE UNITED STATES GOVERNMENT FY 1989 , supra note 4 , at $6 \mathrm{~d}-30$ to -31 .

102. See Principles, supra note 60 , at chs. 5,6 passim.

103. See L. FISHER, supra note 44, at 60 . The term "line item" is apt; each line in an appropriations statute states an amount to be appropriated for a particular item. The concept of line-itemization is relative, however, since every "item" comprises sub-items that are not separately appropriated, see infra text accompanying note 124 .

104. See, e.g., Act of Apr. 10,1869, ch. 15, 16 Stat. 9 ("For lighting the above six buildings, three thousand two hundred and five dollars. ... For compensation of the document file clerk ... the 
appropriations in omnibus legislation; incorporating appropriations for many agencies into one bill discouraged a presidential veto. ${ }^{105}$ The practice of annual appropriations, inherited from England and the colonial governments, ${ }^{106}$ was an additional means of controlling spending.

These practices were designed to achieve effective legislative control over spending. In fact, they did not. Absent a means for Congress to audit or otherwise ensure compliance with its appropriations legislation, ${ }^{107}$ some executive departments simply ignored appropriation limitations and transferred funds freely among accounts. Even when agencies did not improperly transfer funds, "coercive deficiencies" in appropriation accounts mitigated legislative control; by making unauthorized obligations, agencies could impose a moral and political, if not legal, obligation upon Congress to enact supplemental appropriations in order to avoid or rennburse deficiencies in various hine-item accounts. ${ }^{108}$ This system of hne-item detail and numerous supplemental appropriations thus thwarted, rather than ensured, legislative control over expenditure. Congress became mired in appropriation detail while agencies spent as they pleased. ${ }^{109}$

Congress sought to control coercive deficiencies by passing the AntiDeficiency Act of 1905. This law prohibited spending in excess of appropriations, ${ }^{110}$ and it also required agency heads to apportion every appropriation over the fiscal year, in order to ensure adequate funding for the entire year. ${ }^{11}$ Apportioument, however, proved to be incompatible with detailed line itemization in appropriations acts. As President Taft's Commission on Economy and Efficiency noted in 1912, excessive lineitem detail could cause severe administrative difficulties. ${ }^{112}$ The line-item

sum of six hundred dollars."); Act of Apr. 18, 1806, ch. 33, 2 Stat. 384, 385 ("For expense of stationery, printing, and incidental and contingent expenses of the comptroller's office, eight hundred dollars. ... For purchasing books, maps and charts, for the use of the treasury department, four hundred dollars.").

105. See Note, Is A Presidential Item Veto Constitutional?, 96 Yale L.J. 838, 840 (1987).

106. See J. Burns, Controversies Between Royal Governors and Their Assemblies IN THE NORTHERN AMERICAN COLonies 103, 262, 306, 330 (1923) (account of early colonial practices in which legislatures and executives confronted each other over annual appropriations).

107. Cf. L. Wilmerding, supra note 44, at 199-308 (Congress has failed to devise a system of effective post-appropriations control).

108. For further description of coercive deficiencies and Congress' efforts to control them, see CONTROL OF FEDERAL EXPENDITURES: A DocumentARY History, 1775-1894, at 151-59 (F. Powell ed. 1939) [hereinafter CONTROL OF FEDERAL EXPENDITUREs]; L. WiLMERDiNG, supra note 44, passim.

109. See TAFT Commission, supra note 50, at $59-78$ (describing and criticizing the great detail in appropriations acts); see also Legislative Politics U.S.A.: CONGRESS AND THE FoRCes ThAT SHAPE IT vii-xxii (T. Lowi ed. 1962) (discussing difficulties with too much detail in legislation).

110. Anti-Deficiency Act of 1905, ch. 1484, §4, 33 Stat. 1214, 1257-58 (current version at 31 U.S.C. § 1341 (1982)).

111. The current version of the apportionment requirement is at 31 U.S.C. $\S 1512$ (1982).

112. TAFT COMMISSION, supra note 50, at 59-78. 
amounts often were mismatched and inefficient. ${ }^{113}$ Since transfers among lines were not permitted, agencies sought supplemental appropriations for the relatively underfunded accounts. ${ }^{114}$

\section{2. "Lump-Sum Appropriations"}

The massive restructuring and growth of the federal government under Franklin Roosevelt finally forced Congress to refram froin routine, detailed line itemization in appropriation acts. ${ }^{115}$ Instead, Congress resorted to lump-sum appropriations, which consohdated the appropriations for various activities of each federal agency or department. This consolidation both reduced coercive deficiencies and allowed greater administrative flexibility in allotting funds among an agency's activities. ${ }^{116}$ In addition, the President's discretionary power over budget administration was mcreased by legislation and executive orders that transferred apportionment responsibility under the Anti-Deficiency Act froin departinent heads to the Bureau of the Budget ${ }^{117}$ and transferred the Bureau of the Budget from the Treasury to the White House. ${ }^{18}$ The successor to the Bureau of the Budget, OMB, now exercises the apportionment power. ${ }^{119}$

Since the Second World War, appropriations legislation has generally contained less line-item detail than it did in the preceding 150 years. ${ }^{120}$ Instead, appropriations acts fund each broadly defined federal program or activity in one lump sum, termed a budget "account." In recent decades, Congress has "earmarked" relatively few items within each budget account; for example, " $\$ X$ [of the lump sum] may be spent

113. For a recent example of the difficulties caused by excessive line-itemization, see Armster v. District Court, 792 F.2d 1423, 1425 n.3 (9tlı Cir. 1986) (line amount for juror fees too small relative to number of judges authorized).

114. TAFT Commission, supra note 50, at 78.

115. See V. BRowne, supra note 43, at 96-97; L. Fisher, supra note 44, at 62-65; L. W1LMERDING, supra note 44, at 180-95. Roosevelt was also a longstanding proponent of lump-sum appropriations. As Assistant Secretary of the Navy in 1919, le proposed that appropriations for each department's various activities be consolidated, but that no department be allowed to depart from its original budget justification except on the approval of the appropriate congressional cominittees. L. WiLMERDING, supra note 44, at 173-74. Though lie did not use tlie term, Roosevelt was proposing lump-sum appropriations with a "committee veto" over expenditure details. As President, Roosevelt succeeded in achieving lump-suin appropriations without the committee veto.

116. L. WILMERDING, supra note 44 , at 180-84.

117. Exec. Order No. 6166, § 16 (1933), pursuant to Act of March 3, 1933, cli. 212, 47 Stat. $1489,1517$.

118. Exec. Order No. 8248 (1939), 3 C.F.R. 576 (1938-1943).

119. In 1970, the Bureau of the Budget was abolished and its functions were transferred to the newly created Office of Management and Budget witlin the Executive Office of the President. Reorganization Plan No. 2 of 1970, 3 C.F.R. 1070 (1966-1970), reprinted in 5 U.S.C. app. at 1129 (1982).

120. See L. FisHER, supra note 44 , at $65-66,104-06$. 
on travel or entertainment."121 Often, one account includes several objects or programs. ${ }^{122}$ Sometimes, appropriations acts specify several individual programs but do not allocate among them the gross appropriation amount (lump sum) for the account; for instance, " $\$ \mathrm{X}$ [appropriated] for programs $a, b, c$, and $d$," with no earmarking among the programs. ${ }^{123}$

Obviously, the terms "line item" and "lump sum" are relative concepts. Each "line item" is, in turn, a "lump sum" for all objects or activities within that line item. Thus, even where an appropriations act earmarks particular amounts of money for particular programs, the appropriation may accurately be labeled "lump sum" because each program itself includes many discrete activities for which funds are not individually allocated. ${ }^{124}$ Nonetheless, it is fair to say that the budget process as it evolved after the second World War tended toward the "lump-sum" end of the spectrum.

\section{Committee Allocations and "Reprogramming"}

The growing use of lump-sum appropriations in the 20th century did not end tension between Congress and executive agencies over the

121. See, e.g., Department of Transportation and Related Agencies Appropriations Act of 1984, Pub. L. No. 98-78, 97 Stat. 453, 468 (1983) (limiting "official reception and representation expenses" for the CAB to $\$ 5,000$ and for the ICC to $\$ 1,500$ ).

122. See, e.g., Public Works for Water and Power Development and Energy Research Appropriation Act, 1976, Pub. L. No. 94-180, 89 Stat. 1035, 1047 (1975) (appropriation for TVA projects). As the Supreme Court explained in TVA v. Hill, 437 U.S. 153, 164 n.14 (1978), "TVA projects generally are authorized by the Authority itself and are funded-without the need for specific congressional authorization-from lump-sum appropriations provided in yearly budget grants." See also R. Wallace, Congressional Control of Federal SPEnding 144 (1960) ("items, especially in so-called pork barrel appropriations, rarely represent items at all, but, rather, are lump-sum amounts.")

123. See, e.g., H.R. 4560, 97th Cong., 1st Sess. 2-3 (1981) (appropriation of $\$ 3.7$ billion for Employment and Training Administration in Department of Labor), discussed in UAW v. Donovan, 746 F.2d 855 (D.C. Cir. 1984), cert. denied, 474 U.S. 825 (1985). H.R. 4560 was never enacted as a separate statute, but it was enacted by incorporation in four separate continuing resolutions. Act of Oct. 1, 1981, Pub. L. No. 97-51, 95 Stat. 958; Act of Nov. 23, 1981, Pub. L. No. 97-85, 95 Stat. 1098; Act of Dec. 15, 1981, Pub. L. No. 97-92, 95 Stat. 1183; Act of Mar. 31, 1982, Pub. L. No. 97-161, 96 Stat. 22, H.R. 4560 . The total annual amount of $\$ 3.7$ billion was a lump sum to cover five separate programs, as follows:

For expenses necessary to carry into effect [1] the Comprehensive Employment and Training Act of 1973, as amended, [2] sections 236, 237, and 238 of the Trade Act of 1974, as amended (19 U.S.C. 2101), [3] section 51 of the Internal Revenue Code of 1954, as amended (26 U.S.C. 51), [4] sections 210, 211, and 212 of Public Law 95-250, and [5] the Veterans' Employment and Readjustment Act of 1972, as amended (38 U.S.C. 2003A) ...."

UAW, 746 F.2d at 858 (quoting H.R. 4560, 97th Cong., 1st Sess. 2 (1981)).

124. See, e.g., H.R. 4560, supra note 123. Although this appropriation did not allocate funds among the five programs it funded, it did earmark $\$ 2,001,000$ for the National Commission for Employment Policy, which was a subprogram under the Comprehensive Employment and Training Act of 1973. Id. at 2. 
allocation of appropriated funds. As lump-sum appropriations became the statutory norm, a countervailing practice developed. This practice, known as "reprogramming" review, permits appropriations committees in Congress to exercise significant control over allocation of appropriations. Unlike formal "committee veto" provisions, which presidents consistently vetoed ${ }^{125}$ and which courts and scholars have long recognized as constitutionally infirm, ${ }^{126}$ reprogramming review is a nonstatutory, informal source of committee authority over administration of appropriations. ${ }^{127}$

Many federal agencies and their congressional appropriation subcommittees routinely agree to a set of reprogramming procedures. Most commonly, the agency agrees to obtain subcommittee approval before departing substantially from-that is, "reprogramming"--the expenditure breakdown that the agency advanced in its budget justifications or that committee adopted in the report accompanying the agency's appropriations. There is a general agency practice of adhering to reprogramining agreeinents-a practice so well established that in most cases the agreements are treated as "binding" by all concerned. ${ }^{128}$

Nonetheless, it appears that as a matter of law an admmistering agency has discretion over how to allocate each lump-sum appropriation; $;^{129}$ this authority is the converse of the agency's legal obhgation to adhere to every statutory line itemization. ${ }^{130}$ Both the advisory opmions

125. Presidents Wilson, Hoover, Roosevelt, Truman, Eisenhower, Kennedy, and Johnson ail vetoed appropriations acts that contained formal committee veto provisions. See Separation of Powers: Hearings Before the Subcomm. on Separation of Powers of the Senate Comm. on the Judiciary, 90th Cong., 1st Sess. 215-28 (1967) (appendix to statement of Assistant Attorney General Frank M. Wozencraft); see also INS v. Chadha, 462 U.S. 919, 969 n.5 (1983) (White, J. dissenting) (Presidents Kennedy and Johnson opposed committee veto but supported legislative veto).

126. See, eg., Ginnane, The Control of Federal Administration by Congressional Resolutions and Committees, 66 HARv. L. REv. 569, 599-609 (1953); Comment, Congress Steps Out: A Look at Congressional Control of the Executive, 63 CALIF. L. REv. 983, 1053-65 (1975); Am. Fed. of Gov't. Emp'ees v. Pierce, 647 F.2d 303, 306 (D.C. Cir. 1982).

127. Another countervailing practice that became common after the New Deal was the insertion of legislative veto provisions in legislation other than appropriations that delegated significant authority to the exeeutive. Like reprogramming arrangements, legislative veto provisions sought to retain some congressional control over administration without resorting to legislative specification of administrative details. The Supreme Court held the legislative veto unconstitutional in INS v. Chadha, 462 U.S. 919 (1983), discussed infra notes 306-15 and accompanying text.

128. One of the few discussions of reprogramming is found in L. FisHER, supra note 44, at 7598. The budgetary process is preserved by agencies abiding by Congress' informal designations of how the money should be spent. Id. at 76.

129. UAW v. Donovan, 746 F.2d at 861 ; Blackhawk Heating \& Plumbing Co. v. United States, 622 F.2d 539, 548 (Ct. Cl. 1980); see also H.R. REP. No. 662, 93d Cong., 1st Sess. 16 (1973); PRINCIPLES, supra note 60 , at 2-26 to $-30,5-95$.

130. During the first two decades of the Republic, it was occasionally argued that the executive was bound only by the gross aggregate amounts appropriated by Congress, not every statutory lineitem amount. See CoNTrol OF FEDERAL Expenditures, supra note 108, at 108; $L$. WILMERDING,supra note 44, at 50-56. In 1809, Congress enacted general legislation confirming the 
of the Comptroller General ${ }^{131}$ and at least one congressional committee report ${ }^{132}$ have acknowledged that expenditure breakdowns im an agency's budget justifications or $\mathrm{m}$ committee reports are not binding on the executive. Such spending detail may be "politically" binding, since an agency will find it advantageous to "keep faith" with Congress, but the agency may in its discretion depart froin them. ${ }^{133}$ As the Court of Appeals for the District of Columbia Circuit recently held in UAW v. Donovan, ${ }^{134}$ an agency is bound only by statutory allocations of lump-sum appropriations. $U A W$ involved an unearmarked, lump-sum appropriation for five programs. ${ }^{135}$ In an opinion by then-Judge Scalia, the court held that the agency could spend all, some, or none of the funds on any program. "A lump-sum appropriation leaves it to the recipient agency (as a matter of law, at least) to distribute the funds among some or all of the permissible objects as it sees fit."136 Thus, obtaining committee approval for reprogramming is a matter of comity between the branclies. Of course, Congress liolds the ultiniate power. If Congress wants to ensure that a specific program receives a certain amount of budget authority, it may so provide in the relevant appropriations act. ${ }^{137}$

In fact, appropriations acts seldom contain tlie detailed spending

prevailing view that the executive was bound by every statutory limitation in an appropriation act. Act of Mar. 3, 1809, ch. 28, 2 Stat. 535 ("[S]ums appropriated by law for each branch of expenditure in the several departments shall be solely applied to the objects for which they are respectively appropriated, and to no other."). This principle is now codified at 31 U.S.C. $\S 1301$ (1982).

131. See, e.g., 17 Comp. Gen. 147, 150 (1937) ("The amounts of individual items in the estimates presented to the Congress on the basis of which a lump-sum appropriation is enacted are not binding on administrative officers unless carried into the appropriation act itself."); see also 55 Coinp. Gen. 812, 819-20 (1976); 55 Comp. Gen. 307, 318-19 (1975); 20 Comp. Gen. 631, 632 (1941). The concept is explicated at length in PRiNCIPLES, supra note 60, at 5-95 to -103 .

132. H.R. REP. No. 662, supra note 129 , at 16 , stated:

In a strictly legal sense, the Departınent of Defense could utilize the funds appropriated for whatever programs were included under the individual appropriations accounts, but the relationship with the Congress demands that the detailed justifications which are presented in support of budget requests be followed. To do otherwise would cause Congress to lose confidence in the requests made and probably result in reduced appropriations or line-item appropriation bills.

133. 55 Comp. Gen. 307, 318-19, 325 (1975).

134. 746 F.2d 855 at $860-61$.

135. This was the appropriation set forth in H.R. 4560, supra note 123. See UAW, 746 F.2d at 858.

136. $746 \mathrm{~F} .2 \mathrm{~d}$ at 861 . The statement in $U A W$ is overbroad, however. It would seem that in allocating its lump-sum appropriations, an agency cannot simply ignore legislative intent as revealed in the legislative history of the appropriations statute. See Morton v. Ruiz, 415 U.S. 199, 229-232 (1974) (agency must spend appropriations over whole range of authorized activities in accordance with legislative intent).

137. As put by a leading authority on the constitutional limitations on executive spending power: "[Y]ou know full well that, if you seriously want to appropriate on a line-item basis in an appropriations bill, you can do that by drafting the bill to achieve that end. ... You have the tools to handcuff the President." Oversight on the Impoundment Control Process: Hearing Before the Task Force on Enforcement, Credit, and Multiyear Budgeting of the House Comm. on the Budget, 97th Cong., 2d Sess. 165 (1982) (statement of Prof. John R. Kramer). 
breakdowns that are in committee reports and executive budget submissions. As noted by the Taft Commission and later commentators, excessive detail ties the hands of admmistrators, and it ill serves both Congress and the executive to place rigid strictures on the administration of federal programs. ${ }^{138}$ Moreover, with the growth in the federal budget, there are already thousands of line allocations even without further legislative specification.

The enactment of GRH suggests that the practice of lump-sum appropriations with "reprogramming" limitations inay have achieved only a temporary equilibrium in the historic struggle between Congress and the President over the proper extent of detail in appropriations legislation. As Part III demonstrates, ${ }^{139} \mathrm{GRH}$ provides incentives for greater line-item detail in both appropriations legislation and accompanying committee reports.

\section{The Procedural Changes of 1974}

Prior to the Congressional Budget and Impoundment Control Act of $1974,{ }^{140}$ the legislative appropriations process was neither unified nor comprehensive. ${ }^{141}$ Curious and uncoordinated legislative procedures hid the imphicit tradeoffs involved in fiscal legislation from both the public and Congress, and there was a chromic failure to consider revenues and expenditures in relation to each other. ${ }^{142}$ Moreover, in the 1960s and

138. See TAFT Comm1ssion, supra note 50; see also Fisher, Presidential Spending Discretion and Congressional Controls, 37 LAW \& CoNTEMP. ProBs. 135, 171 (1972) (emphasis added):

Appropriations are made many months, and sometimes years, in advance of expenditures. Congress acts with imperfect knowledge in trying to legislate in fields that are highly technical and constantly uudergoing change. New circumstances will develop to make obsolete and mistaken the decisions reached by Congress at the appropriation stage. It is not practicable for Congress to adjust to these new developments by passing large numbers of supplemental appropriation bills. Were Congress to control expenditures by confining administrators to narrow statutory details it would perhaps protect its power of the purse but it would not protect the purse itself. Discretion is needed for the sound management of public funds.

139. See infra text accompanying notes 295-328.

140. Pub. L. No. 93-344, 88 Stat. 297 (codified as amended in scattered sections of 1, 2 \& 31 U.S.C.) (discussed supra note 58).

141. Aaron Wildavsky's incrementalist model aptly described the pre-Budget Act process. Under his model, expenditures grew steadily over time and were financed by cconomic growth, obviating the need for reallocation of funds from one program to another. Rarely did congressional committees scrutinize the desi1ability of programs. The budget base of each program was usually secure, so debate focused on the amount of incremental increase. "Calculating budgets in monetary increments facilitates bargaining and logrolling. It becomes possible to swap an increase here for a decrease there or for an increase elsewhere without always having to consider the ultimate desirability of programs blatantly in competition." A. WILDAVSKY, THE Politics of THE Budgetary Process 136-37 (4th ed. 1984).

142. See supra notes $45-47$ and accompanying text. Congress considered revenues and expenditures in isolation. The House Ways and Means Committee and the Senate Finance Committee had exclusive jurisdiction over revenue decisions, while the House and Senate appropriations committees made all spending decisions. 
early 1970s, appropriations committees did not exercise their traditional restraint on the budgetary process because Congress had exempted many programs from appropriations control through backdoor spending mechanisms. ${ }^{143}$ Because much backdoor spending was "off-budget," 144 the annual budget deficit figure was usually misleading. ${ }^{145}$

The 1974 legislation, precipitated by the political and constitutional crises of Watergate and presidential impoundment of funds, ${ }^{146}$ was intended to achieve more comprehensive and effective congressional control over budget policies. ${ }^{147}$ The 1921 Budget and Accounting Act had given the President the resources (im the Bureau of the Budget, later $\mathrm{OMB}$ ) to analyze the government's spending needs, weigh various goals, and decide fiscal priorities. In the 1974 Act, Congress sought to develop comparable capabilities for itself.

Although adopted by statute, the 1974 reform addressed internal

143. See supra notes 78-100 and accompanying text. For a discussion of the power and ethos of appropriation committees-and their chairmen-see generally J. PressMaN, House v. SENATE: CONFLICT in THE APPROPRiations Process (1966). Although in the late 1960s and early 1970s Congress enacted purported "ceilings" on total federal expenditures, the ceilings were ignored and hence were exceeded. See L. LeLoup, supra note 100 , at 8.

144. "Off-budget" entities are government "entities whose transactions . . . have been excluded from budget totals under provisions of law." GLOSSARY, supra note 60, at 68 .

145. Because moving a program "on" or "off" budget has implications for the on-budget deficit, political considerations relating to the deficit infiuence the decision to list a program "on" or "off" budget. For example, President Johnson's Commission on Budget Concepts recommended moving social security on-budget and President Johnson carried out this recommendation, thereby reducing the budget deficit since the social security fund had a surplus. President's Message to the Congress Transmitting the Budget for Fiscal Year 1969, 4 WeekLy CoMP. PRES. Doc. 148, 162 (Feb. 5, 1968). On the other hand, President Reagan proposed moving social security off-budget to remove its "deceptive" effect on the budget, since its funds cannot be spent for other purposes. Remarks and a Question-and-Answer Session With Reporters, 21 WEEkLy COMP. PRES. Doc. 960, 962 (Aug. 12, 1985). A little-noticed provision of GRH does, in fact, return social security to off-budget status beginning in FY 1993. GRH 1985, supra note 10, § 261(b), 42 U.S.C. § 911(a) (Supp. IV 1986). The result will be to make the on-budget deficit larger than the total budget deficit. Although in I969 the federal government had explicitly adopted the concept of a "unified budget"-a budget which theoretically reflects the revenues and spending of all parts of the government-baekdoor treatment often permitted programs to remain "off budget." THE PRESIDENT's COMMISSION ON BUDGET CONCEPTS, REPORT 11-15 (1967) rccommended that the coneept of a unified budget be adopted.

I46. For the most thorough examination of the genesis of the eonstitutional and legal issues pertaining to impoundment, at least from the vantage point of the early 1970s, see Abaseal \& Kramer, Presidential Impoundment Part I: Historical Genesis and Constitutional Framework, 62 Geo. L.J. 1549 (1974); Abascal \& Kramer, Presidential Impoundment Part II: Judicial and Legislative Responses, 63 GEO. L.J. 149 (1974). Similarly, for the legislative genesis of the 1974 budget legislation, see A. ScH1CK, supra note 82 , at 53-8I.

147. The legislative history of the 1974 budget legislation refleets a variety of purposes, only one of which was reduction in the size and frequency of deficits. Congress' overriding coneern was that due to its fragmented budget process, it had "lost the power of the purse to the executive branch." House Comm. oN The Budget, 94TH CONG., 2D SEss., The Congressional Budget and IMPOUNDMENT CONTROL ACT OF 1974: A General Explanation 1-2 (Comm. Print 1976). See generally J. Pfiffner, The President, the Budget and Congress: Impoundment and the 1974 BudGET ACT (1979). 
legislative procedures ${ }^{148}$ which usually are enforceable only by point-oforder objections. ${ }^{149}$ The legislation created new budget committees in each House to pursue an integrated, systematic approach to federal taxing and spending, ${ }^{150}$ made it procedurally more difficult for Congress to establish additional backdoor spending programs, ${ }^{151}$ and placed many backdoor spending programs "on budget." 152 In addition, the reform established the Congressional Budget Office (CBO) to help Congress examine each spending program both in relation to other programs and im relation to federal revenues. ${ }^{153}$

The heart of the new legislation was the invention of a new, nonstatutory congressional action, the annual "congressional budget resolution." Drafted under the aegis of the budget committees, the congressional budget resolution is supposed to estabhish overall national fiscal pohicies. Each resolution specifies five target "aggregates": total additional (or "new") budget authority, total annual revenues, total annual outlays, the deficit, and the gross public debt. ${ }^{154}$ The 1974 budget law was intended to make appropriations consistent with the five aggregate targets of the resolution. ${ }^{155}$

148. "Each House [of Congress] may determine the Rules of its Proceedings ...." U.S. CoNST. art. I, $\S 5$, cl. 2. Titles III, IV, and IX of the 1974 legislation, which were the heart of the bill, dealt almost exclusively with internal rules. GRH amends these provisions of the 1974 legislation. See infra notes 193-202 \& 389-92.

149. A point of order is a procedural objection raised by a Member [of Congress] alleging a departure from rules governing the conduct of business. It differs from an absolute prohibition in that (a) it is always possible that no one will raise it, and (b) if raised, it may or not be sustained. Also, some measures may be considered under special resolutions waiving points of order.

PRINC1PLES, supra note 60, at 2-17; see also infra notes $161,163$.

150. Congressional Budget Act of 1974, Pub. L. No. 93-344, $\S \S 101-102,88$ Stat. 297, 300-02 (amended 1985).

151. Id. $\$ 401,2$ U.S.C. $\$ 651$ (1982) (amended 1985). The 1974 legislation placed procedural restrictions upon legislation establishing new entitlement authority but did not prohibit new entitlements. As enacted in 1974, the budget legislation required an authorizing committec, see supra note 78, to submit proposed new entitlement programs to the appropriations committec if the program's costs would exceed the budget authority allotted to the authorizing committee under the last concurrent resolution. The appropriations committee had 15 days to offer amendments to the proposal. See Donnelly, Uncontrollable U.S. Spending Limits Hill Power of the Purse, 38 CoNG. Q. WEEKLY REP. I17, 121 (1980) ("In practice, the main effect of this provision has been to give the Appropriations committees some additional bargaining power, if not control, over the size and scope of new entitleınents.").

152. Congressional Budget Act of 1974, $\S 601,2$ U.S.C. $\S 1105$ (1982) (amended 1985). See supra note 145 and accompanying text.

153. Id. $\S \S 201-203,2$ U.S.C. $\$ \S 601-603$ (1982) (amended 1985).

154. Id. $\S \S 301(\mathrm{a}), 310(\mathrm{a}), 2$ U.S.C. $\S \S 632(\mathrm{a}), 641(\mathrm{a})$ (1982) (amended 1985). The budget resolution also sets totals for the 21 functional classifications in the federal budget. Each "function" is a general policy area (National Defense, International Affairs, etc.). See S. Collender, supra note 94 , at $7-9$.

155. Congressional Budget Act of 1974, § 311, 2 U.S.C. $\S 642$ (1982) (amended 1985). The 1974 legislation required Congress to pass a preliminary budget resolution by May 15 that set a target floor for total revenues and target ceilings for total budget authority, total budget outlays, 
The most important of the five aggregates in the budget resolution was the first. This "new" budget authority is the sum of all new appropriations and any other newly available spending authority (from permanent appropriations or backdoor spending programs) that agencies will receive in the coming fiscal year. ${ }^{156}$ The outlay, on the other hand, is merely a dependent estimate, calculated on the basis of the current and previous years' "new" budget authority. ${ }^{157}$ Prior to GRH's amendments of the 1974 Budget Act, the "deficit" was the policy variable with the least analytic significance, for it simply reflected the difference between revenues and outlays in the coming fiscal year.

Within a few years after passage of the 1974 budget reform legislation, however, it became evident that Congress had not achieved the budget control it had sought. The deficit had grown, ${ }^{158}$ backdoor spending had increased, ${ }^{159}$ and in fact new entitlement programs had been established. ${ }^{160}$ In part, the failures of the budget process after 1974 can be traced to Congress' own failure to abide by the 1974 legislation. Both Houses routinely violated the Act's procedural requirements. ${ }^{161}$ Congress rarely passed budget resolutions on time $e^{162}$ and usually failed to

total budget surplus or deficit, and total public debt. The 1974 Act further provided for a final budget resolution, to be passed by September 15, which would set "binding" ceilings on the above aggregates and which could be modified ouly by subsequent resolutions. In the event that spending and revenue legislation passed during the year exceeded the aggregates set forth in the second resolution, the Act provided a "reconciliation" procedure; appropriations and substantive committees would be instructed to cut a specified amount from their programs to bring the total within the established aggregates. See H.R. ReP. No. 147, 93d Cong., 1st Sess., 3-6, 14-17 (1973); S. REP. No. 579, 93d Cong., 1st Sess., 7-11 (1973); H.R. ReP. No. 658, 93d Cong., 1st Sess. $19-26$ (1973), reprinted in 1974 U.S. CODE CONG. \& ADMIN. NEws 3462, 3466-72.

156. See BUdGet of THE UNITED STATES GOVERNMENT FY 1989, supra note 4, at 6d-1 to -4.

157. Id.

158. In FY 1974, the annual deficit was $\$ 6$ billion. By FY 1980 , it had grown to $\$ 74$ billion. See BUdget of THE UNITEd States Government FY 1989, supra note 4, at 6g-40 to -41, Table 19 ("Federal Finances and the Gross National Product, 1970-1991").

159. See Budget of the UNITEd States GOVERNMENT FY 1986 at $9-44$ to -45 , Table 18 (1985) ("Controllability of Budget Outlays 1976-1988," showing increase in entitlement payments and outlays from prior-year contracts).

160. For example, when the Child Nutrition Amendments of 1978, Pub. L. 95-627, 92 Stat. 3603 (codified in scattered sections of 4, $26 \& 42$ U.S.C.), were reported to the appropriations committees, the appropriations committees negotiated an agreement with the authorizing agriculture committees to limit the entitlement to two years, with the remainder of the 4-year program subject to the appropriations process. See Donnelly, supra note 151, at 121-22; see also J. BenNeTt \& T. DiLorenzo, Underground Government: The OfF-Budget Public Sector 135-38 (1983).

161. For example, the House lias waived points of order against consideration of (1) bills providing advance entitlement authority, in violation of $\S 303$ (a)(4) of the 1974 Budget Act, 2 U.S.C. § 634(a)(4) (1982), see H.R. Res. 1490, 94tl Cong., 2d Sess., 122 CoNG. Rec. 27,542 (1976); (2) bills providing new contract authority, in violation of $\S$ 401(a) of the 1974 Act, 2 U.S.C. $\S 651$ (a) (1982) (amended 1985), see H.R. Res. 1519, 94th Cong., 2d Sess., 122 CoNG. REc. H30,219-20 (1976); and (3) bills providing new entitlement authority effective prior to the new fiscal year, in violation of $\S 401$ (b)(l) of the 1974 Act, 2 U.S.C. $\S 651$ (b)(1) (1982), see 122 CoNG. REc. H34,074 (1976).

162. Between 1976 and 1983, Congress met the deadlines for enacting the first and second 
adhere to them after passage. ${ }^{163}$

The failures of the budget process after 1974 suggest also that the 1974 legislation itself was inadequate. The legislation did not hmit expenditures for existing backdoor spending prograins ${ }^{164}$ and failed to prevent the enactinent of new ones. Although the 1974 Act made new backdoor spending procedurally more difficult to estabhsh, its procedural obstacles could be avoided since they were subject only to point-of-order enforcement. ${ }^{165}$ Likewise, the 1974 legislation did not limit other types of nonappropriated spending, including most permanent appropriations, ${ }^{166}$ revolving funds, ${ }^{167}$ offsetting collections, ${ }^{168}$ and loan guarantees. ${ }^{169}$ As a result, these forms of funding grew substantially. Congress found credit programs, such as guaranteed loans, particularly alluring; they involved little or no imitial outlay, and the contingent liabilities they represented were not reflected in the budget, which employed cash accounting. 170

budget resolutions, see supra note 155, only once. See Konigsberg, Amending the Congressional Budget Act of 1974, 11 J. LEGIs. 90, 99-107 (1984).

163. For example, on March 8, 1977, the House passed a resolution waiving a point-of-order objection to a violation of $\S 311$ (a) of the Budget Act, 2 U.S.C. $\S$ 642(a) (1982) (amended 1985). That section prohibits either House from considering any bill or amendment that reduces revenues below the linit established in the second concurrent resolution. The House proceeded to consider the Tax Reduction and Simplification Act of 1977. See H.R. Res. 360, 95th Cong., 1st Sess., 123 CoNG. REc. 6582-84 (1977). On October 1, 1976, the Chair sustained a point of order in the Senate against a similar amendment, but the objection was subsequently withdrawn and the amendment was considered. See 122 CoNG. REc. 34, 554-57 (1976); see also H.R. Res. 720, 96th Cong., 2d Sess., 126 CoNG. Rec. 17,372-73 (1980); H.R. Res. 688, 96th Cong., 2d Sess., 126 CoNg. Rec. 12,818-19 (1980); H.R. Res. 633, 96th Cong., 2d Sess., 126 CoNG. REC. 10,999-11,001 (1980); H.R. Res. 529, 96th Cong., 2d Sess., 126 CoNG. REC. $581-84$ (1980).

164. Congressional Budget Act of 1974, $\S 401$ (a), 2 U.S.C. $\$ 651$ (a) (1982) (amended 1985).

165. See supra note 149.

166. See supra note 74 and acconpanying text.

167. A revolving fund is a fund from which money is continually withdrawn and subsequently replaced to finance future withdrawals. Congress authorizes agencies with revolving funds to spend the receipts they collect without annual renewal of budget authority. The Federal Deposit Insurance Corporation and inost direct loan programs are financed in this way. See PRINCIPLES, supra note 60, at 5-75.

168. See Budget OF THE UNITED StaTes GovernMENT FY 1989, supra note 4, at 6e-14 to 15 ("offsetting collections credited to appropriation or fund accounts" increase net appropriated funds). The GAO refers to these as "reinibursements." 62 Comp. Gen. 70,73 (1982). They are also sonietimes terined "monetary credits." For example, under the 1974 Act, reductions in royalty payments due for inining on federal land were treated as "credits," not appropriations.

169. Under loan guarantee programs, the federal government guarantees repayment of part or all of the principal and sometimes even the interest upon the borrower's default. See S. CoLLENDER, supra note 94, at 166. The six largest loan guarantec programs are the Federal Housing Administration, low rent public housing, guaranteed student loans, Veterans Administration housing, the Export-Import Bank, and the Commodity Credit Corporation (farm price supports). BUDGET OF THE UNITED STATES GOVERNMENT FY 1989, supra note 4, at F-19 to -22 .

170. See Budget of THE United STATES Government FY 1989, supra note 4, at F-5 to -6 . The loan guarantee remains unrecorded in the budget unless and until the federal government pays on the obligation. 
Beginning with fiscal year 1981, Congress informally adopted a variant of the original 1974 budget reform that would subject a greater portion of the rising, "uncontrollable" budget"171 to annual legislative control. Termed "reconciliation," the new procedure" annual budget resolution to include the spending totals for statutory entitlements and other forms of backdoor spending. ${ }^{173}$ As it turned out, however, reconciliation was also inadequate as a mechanism to bring expenditures into balance with revenues. In the early 1980s, committees with jurisdiction over entitlement spending routinely exceeded reconciliation instructions, and the amount of supplemental appropriations (enacted outside the regular budget process) continued to grow. ${ }^{174}$

Both the comprehensive budget process prescribed by the 1974 Act and the reconciliation approach attempted since 1981 increased Congress' opportunities to scrutinize individual expenditures annually. Ironically, this enhanced scrutiny made it more difficult politically to achieve legislative control of the budget. By making every program vulnerable every year, the process required Congress to expend more effort on negotiation, logrolling, and the making of alhances. ${ }^{175}$ The increased conflict and interdependence among various interest groups and members of Congress merely entrenched existing programs and led Congress to ignore its self-proclaimed aggregates, instructions, and deadlines. ${ }^{176} \mathrm{By}$ the mid-1980s, the budget and the budget process were facing a

171. See supra text accompanying notes 101-02.

172. The procedure was not wholly devised in 1981. The 1974 Act had provided for a form of "reconciliation" between the "preliminary" and the "final" congressional budget resolutions. See supra note 155. Since 1974, however, Congress enacted a second congressional budget resolution only once. In every other year, the initial resolution was in fact the only resolution. Accordingly, before 1981 there had been no attempt at "reconciliation" control over entitlements and other mandatory spending.

173. Under reconciliation practice since 1981 , the annual concurrent budget resolution included instructions directed to authorizing committees, to appropriations committees, and to tax committees. These instructions, which set the amount of new spending (or spending reduction) that committee legislation could provide for the coming year, encompassed credit programs, entitlements, contract authority, and borrowing authority, as well as "regular" appropriations. Reconciliation legislation, drafted to conform with reconciliation instructions, amends underlying statutory authorizations for backdoor spending. See S. Collender, supra note 94, at 40-41.

174. See Ellwood, Budget Control in a Redistributive Environment, in MAKING ECONOMIC Pol.ICY IN CONGREss 69, 78-79 (A. Schick ed. 1983).

175. Ellwood suggests that a strict reconciliation process may make it impossible to forge alliances, thus paralyzing the legislature. Id. at 93-94.

176. The move from fragmented to comprehensive budgeting in 1974 may be seen as a shift from "distributive" to "redistributive" budgeting. The former allocates spending increases among different programs, generally leaving the budget base of each program intact. See A. WILDAVSKY, supra note 141, at 135 . Winners know they have won, but the losers (whose budgets remain the same) do not know they have lost-an illusion comporting with Congress' desires. The 1974 legislation, particularly since reconciliation, requires "explicit decisions on who shall lose." A. Schick, Reconciliation and the Congressional Budget Process 34 (1981). 
"crisis." 177

\section{II}

\section{The Challenge Of Gramm-Rudman-Hollings}

\section{A. The New Political Economy}

The existence of a budget crisis despite the procedures of the 1974 Budget Act suggested to some that Congress as an imstitution was simply unable to restrain spending in relation to revenues. Although deficit reduction was not originally the overriding goal of the 1974 reform, the procedures it set in place were meant to ensure that Congress would tax and spend with dehiberation and accountability. Moreover, by increasing Congress' capabilities and apparent authority, the 1974 legislation shifted the institutional responsibility for budgeting; it was no longer possible to view the federal budget as basically the President's budget, with adjustments by the Congress. Indeed, the legislation engendered the opposite perception-that the budget was Congress' creation. In retrospect, this result is not surprising, but Congress may not have fully anticipated the political costs in 1974 .

The dramatic increase in deficits under the procedures established by the 1974 Budget Act lent support to the argument advanced by economist James M. Buchanan ${ }^{178}$ and other conservative theorists ${ }^{179}$ that growth in the deficit is hinked to growth in federal expenditures, and that both are inherent in our constitutional democracy. ${ }^{180}$ They argued that a democratically elected legislature has a built-m political bias in favor of

177. Cf. Bowsher v. Synar, 106 S. Ct. 3181, 3193 (1986); id. at 3205 (Stevens, J., concurring); id. at 3205 (White, J., dissenting); id. at 3220 (Blackmun, J., dissenting).

178. Janes M. Buchanan, a professor of economics at George Mason University, received the 1986 Nobel Prize in Econounics for his contributions to the development of public choice theory, which has been called the "philosophical underpinning" of GRH. See Wash. Post, Oct. 17, 1986, at Al, col. 1-2.

179. See R. Wagner, R. Tollison, A. Rabushka \& J. Noonan, Balanced Budgets, Fiscal ResponsibilitTy, AND THE CONSTITUTION 10-11 (1982); Aronson \& Ordeshook, $A$ Prolegomenon to a Theory of the Failure of Representative Democracy, in AMERICAN REEvolution: Papers and Proceedings 23 (R. Austen \& B. Sears, eds. 1977). For another perspective on the need for a constitutional limitation on expenditure, see Wildavsky, Constitutional Expenditure Limitation and Congressional Budget Reform, in THE CONGREssional Budget Process AfTer Five Years 87, 97-98 (R. Penner ed. 1981).

180. Buchanan traces the growth in federal expenditures and the deficit to 1960 , when Keynesian econounic theory gained widespread acceptance in the United States. Buchanan \& Wagner, Contemporary Democracy and the Prospect for Fiscal Control: Initial Thoughts About and Final Reactions to the Conference, in FisCAL RESPONSIBILITY IN CONSTITUTIONAL DEMOCRACY 1, 2 (J. Buchanan \& R. Wagner eds. 1978) [hereinafter Fiscal Control]. The Keynesian model set "full employment" as its goal and dictated government intervention when employment fell beneath the optimum level. It also increased revenues relative to outlays during periods of excess deinand. Buchanan and Wagner contend that Keynesian fiscal policies cannot work within deinocratic institutional settings, and that Keynes presupposed a different economic and political context than 
expenditures and against taxation. Each member of Congress finds it advantageous to support other members' expenditure projects in return for their support for the member's own desired programs. There is no prevailing constituency for taxation, however. ${ }^{181}$ In the past, this inherent political bias was restramed by the pre-Keynesian belief, of "moral" dimension, in a balanced budget. ${ }^{182}$ As this unwritten prescription against deficits lost its moral force, ${ }^{183}$ Congress allowed expenditures to grow disproportionately to revenues, leading to deficits ${ }^{184}$ and inflation. ${ }^{185}$

While this theory is in many respects unsatisfactory, ${ }^{186}$ experience

that of the modern American state. Buchanan \& Wagner, The Political Biases of Keynesian Economics, in id. at 79, 84-85 [hereinafter Political Biases].

181. From the vantage point of voters, budget deficits (whether created by increased expenditures or tax cuts) produce only "winners" in the budget process. Buchanan \& Wagner, Political Biases, supra note 180, at 92; see also Ellwood, supra note 174, at 93-94. Budget surpluses, on the other hand, produce only losers. Buchanan \& Wagner, Political Biases, supra note 180, at 89. Politicians and bureaucrats, it has been argued, are principally concerned with "enhancing [their] power, protecting [their] perks and getting reelected." Banks, A Talk with the Nobel Laureate, FORBES, Nov. 17, 1986, at 108. Thus, there is an inherent political bias toward deficits.

182. See Buchanan, The Moral Dimension of Debt Financing, in A NATION IN DEBT 102, 10405 (R. Fink \& J. High eds. 1987).

183. See Buchanan \& Wagner, Fiscal Control, supra note 180, at 1,3-4. Buchanan and Wagner state that within the pure Keynesian paradigm, despite year-to-year fluctuations, the budget should balance out overall. Institutional biases of democratic governments, however, prevent the symmetrical application of Keynesian budget principles, so that the budget is balanced in neither the short term nor the long terin. Id. at 4-5.

184. Annual deficits are stated, of course, in current dollars. An alternative way to ineasure the size of the cumulative federal debt is as a proportion of GNP. That proportion is far smaller now than it was in the years immediately following World War II. See P. Samuelson \& W. Nordhaus, ECONOMICs 358, 360 (12th ed. 1985); see also BUDGET OF THE UNITED STATES GOVERNMENT FY 1989, supra note 4, Historical Tables, Table 1.2 ("Summary of Receipts, Outlays, and Surpluses or Deficits (-) as Percentages of GNP: 1934-1993") (showing much more significant deficit increase in 1980 s than in 1970s). Presumably, Buchanan would question the assumption that the natural or correct level of deficit growth is proportional to GNP.

185. While Buchanan appears to accept that federal deficits directly cause inflation, he ignores the impact of inflation on the federal deficit. Stated in constant dollars, of course, the deficit has risen less precipitously than appears if current dollars are used. More significantly, if adjusted for capital gains (or losses) incurred by the federal government as real interest rates change, and adjusted for the difference between nommal and rcal interest payinents on the federal debt, then the federal budget had only a small deficit (or even a surplus) for the three decades prior to the early 1980s. See Eisner \& Pieper, A New View of the Federal Debt and Budget Deficits, 74 AM. EcoN. REV. 11, 23 (1984) ("[T] he federal budget may properly be viewed as more frequently in surplus than in deficit."). Eisner and Pieper focus on the macro-economic significance of real federal debt; Buchanan is concerned with the political implications of the growing disparity between nouninal annual revenues and expenditures.

186. See supra notes 184-85. Additionally, it may be noted that congressional logrolling cannot be the only source of growth in federal spending, since ambitious presidential spending programs have also required additional spending. See Ornstein, The Politics of the Deficit, in CoNTEMPORARY ECONomic Problems 311 (P. Cagan ed. 1985). Nor is dissipation of pre-Keynesian moral restraint the only reason for persistent deficit financing, since those precepts date back over 50 years and the precipitous rise in the peaeetime deficit is more recent. See Stein, The Decline of the BudgetBalancing Doctrine or How the Good Guys Finally Lost, in FISCAL RESPONS1BILITY IN 
under the 1974 Budget Act was consistent with much of Buchanan's argument. Neither a fragmented appropriations process nor a comprehensive budget process appeared able to reduce federal spending. Constituent claims and perceived social and military needs prevailed over the pervasive (but less focused) sentiment to reduce the deficit. ${ }^{187}$ When Congress and the President were forced to address all spending and taxing decisions directly, they spent more and taxed less. This phenomenon was not due to ignorance or inadvertence; the annual deficit grew because of political choices.

GRH is an attempt to avoid the politics of the traditional budget process by imposing legal and institutional constraints against deficit growth. GRH proceeds on Buchanan's premse that there is a political bias towards expenditure and deficits, a bias that the traditional legislative process cannot overcome. ${ }^{188}$ Experience under the 1974 legislation had shown that simply admonishing Congress or the President ${ }^{189}$ would

Constitutional Democracy, supra note 180, at 177. Moreover, deficits were more common before 1932 than Buchanan admits. See L. KIMMel, Federal Budget AND Fiscal Policy, 1789-1958, at 315 (1959). Most problematically, the Buchanan thesis posits deficit-induced inflation as the only constraint on deficits and expenditures, ignoring all voter and politician preferences for limited government or limitation of particular government programs. Cf. Downs, Why the Government Budget is Too Small in a Democracy, 12 WORLD POL. 541, 562-63 (1960) (information costs make governunents unaware of problems in society, leading to smaller budgets than would exist in an ideal world with costless information).

187. See D. Stockman, The Triumph of Polrincs 336-94 (1986). A good arguinent can be nade that the huge deficit growth in the 1980s was due to increased defense expenditures and tax cuts-two of President Reagan's three fiscal goals (the third being a balanced budget)-in combination with an econounic recession. Federal revenues grew at an annual rate of $5.2 \%$ from 1981-1985, compared with a rate of $10.8 \%$ between 1965 and 1980 . Nondefense discretionary spending between 1981 and 1985 grew only $0.6 \%$ annually, compared with $11.0 \%$ between 1965 and 1980. On the other hand, defense spending increased at a rate of $12.5 \%$ in the latter period, coinpared with $7.4 \%$ over the earlier period. See CONG. Res. SERVICE, Budget Deficits: Causes, EfFects, and Some Remedial Options 1, 2 (Feb. 26, 1986).

188. Senator Phil Gramm, the primary architect of GRH, is a former economics professor and has been described as a disciple of Buchanan. Alm, $A$ Gadfly with Clout, U.S. NEWS \& WORLD REP., Dec. 15, 1986, at 56. Buchanan himself describes GRH as reflecting a "recognition by political leaders themselves that they need constramts." Id.

189. It has been suggested that granting the President a line-item veto is an alternative way to achieve significant spending reduction. See Economic Report of the President for FY 1987, supra note 18, at 161; Dixon, supra note 1. But a line-iteln veto by itself merely grants the President ostensible authority to reduce spending. If the President does not desire to cut specific appropriations or cannot politically assume full responsibility for spending cuts, the line-item veto would simply increase the President's budget power vis-a-vis Congress'; it would not result in lower spending, at least in the absence of an externally imposed expenditure ceiling. See Wildavsky, Item Veto Without a Global Spending Limit: Locking the Treasury After the Dollars Have Fled, 1 NoTRE DAme J.L. ETHIcs \& PUB. PoL'y. 165, 175-76 (1985); Holtz-Eakin, Forget the Line-Item Veto, N.Y. Times, Feb. 10, 1988, at 27, col. 3 (nat'l ed.). Presidents have not sought significant spending reductions pursuant to the Impoundinent Control Act. Moreover, even a line-item veto would not give the President authority to cut many so-called "pork barrel" projects, see, e.g., D. STOCKMAN, supra note 187, at 148 (water project is quintessential "pork barrel"), since specific "pork barrel", programs are often listed, not in appropriations acts, but only in accompanying coinmittee reports. See also Earmarked Projects, 20 NAT'L J. 836 (1988); R. WALLACE, supra note 122, at 144. 
not achieve deficit reduction; there had to be an extralegislative means of enforcing the admonition. GRH thus attempts to impose an explicit deficit limitation on the legislative budget process, not by constitutional amendment, ${ }^{190}$ but by legislation that alters the legal framework of congressional decisionmaking on the budget-that is, by rewriting our implicit fiscal constitution.

In order to police congressional budget decisions GRH both commands that the deficit be reduced and creates a novel procedure to enforce this command: "sequestration." Sequestration imposes automatic, across-the-board spending reductions to achieve a specified deficit maximum if Congress and the President fail to do so in the legislative budget process.

A subtle strategic logic underlies this approach to deficit reduction. Under GRH, the goal of the traditional legislative budget process is to avoid sequestration by enacting a deficit-reducing budget. On the one hand, the threat of sequestration must be unattractive enough to provide a strong incentive for Congress and the President to enact a legislative budget meeting GRH's prescribed deficit target. On the other hand, the political liabilities of sequestration cannot be so great as to undermine the credibility of the threat. If the consequences of sequestration are too severe, the President and Congress will simply suspend or repeal GRH rather than allow sequestration to occur. ${ }^{191}$ GRH's amendments of the

190. GRH's strongest proponents clearly would have preferred a balanced budget amendment to the Constitution. See, e.g., Economic Report of the President for FY 1987, supra note 18, at 161; The State of the Union, 23 WeEkly CoMP. Pres. Doc. 59, 62 (Feb. 2, 1987); N.Y. Times, Mar. 20, 1987, at A10, col. 1 (transcript of President's nationally televised press conference on Mar. 19, 1987); see also Balancing the Budget: Hearings on S.J. Res. 55 and S.J. Res. 93 Before the Subcomm. on Constitutional Amendments of the Senate Comm. on the Judiciary, 94th Cong., 1st Sess. 61-62 (1975) (statement of James Buchanan and Richard Wagner); Banks, supra note 181, at 110 ("I'm ambivalent on [GRH] because it's only legislative and [it] took attention away from the need to amend the Constitution." (quoting James Buchanan)); 131 CoNG. Rec. S12,568 (daily ed. Oct. 3, 1985) (asscrtion of Sen. Gramm that GRH is "the strongest provision[] that can be written in statute to force fulfillment of that promise made long ago that we balance the budget").

191. Other commentators have used vivid metaphors and language to make the point that sequestration is the threat, not the goal, of GRH. See Hartman, Gramm-Rudman-Hollings After One Year, in YeAR-END RePORT OF THE 99TH CONGRESS, S. DOc. No. 46, 99th Cong., 1st \& 2d Sess. 168, 173 (1987) (sequestration meant to be "so devastating that compromises would be struck"); R. NeustadT, Presidents, Politics, AND ANAlysis 16 (Brewster C. Denny Lecture Series, May 16, 1986, Institute of Public Policy and Management, Graduate School of Public Affairs, University of Washington) (sequestration as "Doomsday Machine"); J. TOBIN, THE FEDERAL BudGet AND THE ECONOMY 2 (1987) (Nelson A. Rockefeller Center for the Social Sciences at Dartmouth College, William H. Spoor Dialognes on Leadership) (sequestration as "timed guillotine"); Elliott, Regulating the Deficit After Bowsher v. Synar, 4 YALE J. ON REg. 317, 335 (1987) ("purpose" of GRH's automatic sequestration procedures was to create an "unpalatable" mechanism). However, the threat of sequestration cannot be so horrible as to be implausible. $C$. Nalebuff, Credible Pretrial Negotiation, 18 RAND J. ECON. 198 (1987) (litigation threat must be credible). 
traditional legislative budget process and its rules for implementing a sequestration reflect the logic of GRH's incentives, as explained below.

\section{B. The New Regime}

GRH establishes two separate stages of annual budget development. The first stage tightens existing spending controls at each step of the traditional budget process, including presidential budget submission, congressional consideration, and legislative enactinent of revenue and spending legislation. The second stage, which imposes "sequestration," becomes effective only if the traditional budget process fails to produce a budget within GRH's prescribed maximum deficit. Sequestration consists of automatic cancellation of spending authority ${ }^{192}$ in all nonexeinpted federal programs, projects, and activities, pursuant to formulae stated in GRH.

The specific procedures and rules governing these two stages reflect their very different purposes. The first stage, restating and refining the traditional budget process, leaves the entire budget open to political conflict and tension. Under the threat of sequestration, the President and Congress have a strong incentive to forge agreement about the level of each appropriation and other spending measure. The second stage supersedes and operates automatically upon the results of the first stage; it bypasses conflict and imposes spending reductions according to formulae in GRH itself.

\section{Stage One: The Budget Process}

GRH amends the Congressional Budget Act of 1974 to make it procedurally more difficult for Congress and the President to enact an annual budget that increases the federal deficit. It strengthens the legislative budget process by: (1) accelerating the timetable for consideration of budget measures, including the President's proposed budget, congressional budget resolutions and reconciliation legislation, and appropriations; ${ }^{193}$ (2) requiring budget resolutions and reconciliation legislation to include the "credit budget" (primarily loan guarantee prograins) in addition to conventional spendimg programs; ${ }^{194}$ (3) subjecting certain additional forms of backdoor spending (permanent appropriations and monetary credits) to budget control through budget resolutions and rec-

192. GRH provides for permanent cancellation of any sequestered spending authority, except that for trust funds the authority will remain available in the fund for future use. 2 U.S.C. $\S$ 906(a)(2) (Supp. IV 1986). This provision simply ensures that when trust funds are sequestered, the money reverts back to the trust fund instead of the general fund of the Treasury. See National Assoc. of Counties v. Baker, 842 F.2d 369, 377-82 (D.C. Cir. 1988) (sequestration intended to reduce funds permanently, not merely to freeze or defer payment for one fiscal year).

193. GRH 1985, supra note 10, $\$ 201$ (b), 2 U.S.C. $\$ 631$ (Supp. IV 1986).

194. Id. $\S 201(\mathrm{~b}), 2$ U.S.C. $\S \S 632(\mathrm{a})(\mathrm{I}) \&(4), 641$ (a)(1)(D) (Supp. IV 1986). 
onciliation; ${ }^{195}$ and (4) introducing new controls over budget bills, both in committee and in floor debate, to ensure consistency between budget legislation and the budget resolutions and reconciliation instructions. ${ }^{196}$

Perhaps the inost significant Stage One control mechanism is GRH's "deficit neutrality" rule, which prohibits any floor amendment that would, in net effect, increase the projected deficit by exceeding the allocations in the budget resolution. ${ }^{197}$ If an anendment to increase funding for a program would cause the spending ceiling of the budget resolution to be exceeded, then the amendment simultaneously must reduce funding elsewhere in the budget or propose some equivalent revenue gain. This parliamentary imperative that a "loser" be identified for each "winner" discourages floor amendinents to increase funding.

GRH further alters the prior legislative procedures by making the achievennent of a specified deficit reduction the driving force of the entire budget process. Under GRH, both the President's proposed budget ${ }^{198}$ and the congressional budget resolution ${ }^{199}$ inust project a deficit within the statutory maximuin or achieve a prescribed amount of deficit reduction. Originally, GRH specified a maxinum allowable deficit for FY 1987 of $\$ 144$ billion, with the maximums declining by $\$ 36$ billion each year to reach a zero deficit by FY $1991 .{ }^{200}$ However, the 1987 amendinents to GRH extended by two years the time for eliminating the annual deficit. GRH now requires deficit reduction of $\$ 23$ billion for FY 1988 and $\$ 36$ billion for FY 1989. ${ }^{201}$ The inaximum permissible deficits are now $\$ 100$ billion for FY 1990, $\$ 64$ billion for FY 1991, and $\$ 28$ billion for FY 1992. As amended, GRH would eliminate the deficit in FY 1993. ${ }^{202}$ Congress and the President may meet the deficit maximuin by

195. Id. $\S 211,2$ U.S.C. $\$ \S 651(\mathrm{c})(2), 652$ (Supp. IV 1986). GRH also requires two more "aggregate" ceilings in the budget resolution, see supra text accompanying notes 155.57: direct loan obligations and primary loan guarantee commitments. Id., § 201(b) 2 U.S.C. § 632(a)(1) (Supp. IV 1986).

196. One new rule provides that suballocations, broken down to the subcommittee level, may not be exceeded on the floor of either House. Id. § 201(b), 2 U.S.C. § 633(a)-(f) (Supp. IV 1986). Before GRH, only the allocation to the full appropriations committee in each House was enforceable on the floor of Congress; GRH seeks to impose fiscal discipline earlier in the process and in appropriations subcommittees as well as the full committees. In the Senate, but not the House, the suballocations must fall within outlay limitations as well as budget authority limitations. Id.; see also Wehr, Spending Bill Reflects Congress' Wants, Needs, 45 CoNG. Q. WeEkLY ReP. 552 (1987).

197. GRH 1985, supra note 10, § 201(b), 2 U.S.C. § 641(d) (Supp. IV 1986).

198. Id. $\S 241,31$ U.S.C. $\S \S 1105(\mathrm{f}), 1106$ (c) (Supp. IV 1986).

199. Id. § 201(b), 2 U.S.C. § 632(i) (Supp. IV 1986).

200. Id. § 201(b), 2 U.S.C. § 622(7) (Supp. IV 1986) (amended 1987).

201. GRH 1987, supra note 24, §102(a), 2 U.S.C.A. $\$ 901$ (a)(3)(A) (West Supp. 1987).

202. Id. $\S 106($ a), 2 U.S.C.A. $\S 622(7)$ (D) (West Supp. 1987). Both as originally enacted and as amended in 1987, GRH allows a $\$ 10$ billion margin of error. This margin effectively raises the deficit maximums in Stage One by that amount but does not change the amount of required deficit reduction for FY 1988 and FY 1989. Nor does it change the deficit maximums in Stage Two. See 
reducing expenditures, by raising revenues, or by some combination of the two.

Congress understood that merely mandating a deficit-reducing budget would not bring about this result. Congress may choose to ignore its own mandate, ${ }^{203}$ and either House may revise rules governing its budget process. ${ }^{204}$ Impressed with the notion of a pre-Keynesian moral imperative for a balanced budget, GRH's sponsors intended Stage Two of GRH to strengthen legislative resolve to abide by the procedural and substantive requirements of Stage One.

\section{Stage Two \\ a. Expenditure Ceiling}

Although GRH explicitly limits only the deficit, ${ }^{205}$ Stage Two inposes an implicit ceiling on annual federal expenditures. If the Stage One budget process does not achieve the deficit reduction required by the statute, Stage Two "sequesters" spending by the necessary amount. ${ }^{206}$ Of course, Congress could have incorporated automatic tax increases in Stage Two in place of-or in addition to-spending cuts. ${ }^{207}$ Instead, Congress opted ouly for an aggregate spending ceiling. ${ }^{208}$ Both as originally conceived and as amended in 1987, the GRH expenditure ceiling

id. $\S \S 102(a), 106(b), 2$ U.S.C.A. $\S \S 901$ (b), 907(10) (West Supp. 1987) (amending GRH 1985, supra note 10, $\S 251($ a)(2), 257, 2 U.S.C. $\$ \S 901,907$ (Supp. IV 1986)).

203. See supra note 41 ; LELOUP, supra note 100 , at 8 .

204. See 2 U.S.C. $\$ 901$ note on exercise of congressional rulemaking power (Supp. IV 1986); see also infra notes $393-97$ and accompanying text (discussing congressional power to modify internal procedural rules).

205. See supra notes 201-02 and accompanying text (for FY 1988 and FY 1989, deficit limitation stated as deficit reduction amount; for remaining fiscal years, stated as total deficit maximum); see also GRH 1985, supra note 10, § 251(a)(3), 2 U.S.C. § 901(a)(3) (Supp. IV 1986) (amended 1987) (deficit reduction of $\$ 11.7$ billion for FY 1986; deficit maximums for the remaining years).

206. GRH 1987, supra note 24, $\S \S 102(a), 103,2$ U.S.C.A. $\S \S 901-903$ (West Supp. 1987).

207. See Elliott, supra note 191, at 358-61 (proposing budget balancing legislation that would impose automatic tax increases to cover portion of deficit); The Gramm-Rudman Budget Proposal: Hearings Before the Joint Economic Comm., 99th Cong., 1st Sess. 10 (1985) (statement of Prof. Walter Heller that deficit reduction process could provide for "triggered tax increases under specified conditions"); id. at 44 (statement of Prof. Franco Modigliani arguing that GRH is inadequate because, inter alia, it does not raise taxes); see also Wagner, Tax Reform Through Constitutional Limitation: A Sympathetic Critique, 15 CuMB. L. Rev. 475 (1984-1985) (advocating a constitutional amendment to avoid faction-based tax transfer policies). Of course, GRH's expenditure ceiling in Stage Two can be avoided by tax increases in Stage One, as many who voted for GRH undoubtedly anticipated.

208. The amount by which the deficit must be reduced for the coming fiscal year is that year's "deficit excess." GRH 1987, supra note 24, § 102(a)(3), 2 U.S.C.A. § 901(a)(3) (West Supp. 1987); see also Initial Sequestration Report for Fiscal Year 1988, 52 Fed. Reg. 39,410, 39,418 (1987) [hereinafter Initial Sequestration Report FY 1988] (explaining how GRH operates). The effective, though implicit, expenditure ceiling for a particular year, therefore, is equal to estinated expenditures minus the deficit excess. 
becomes operative by default, without reliance on any further legislative action.

The process of calculating and implementing this ceiling is inevitably comphicated; GRH could not simply order a halt in government spending in the midst of a fiscal year whenever the governmenits accounts near GRH's deficit limit. As the experience of the previous century demonstrates, agencies adinmistering federal programs must apportion available budget authority throughout the year in order to avoid coercive deficiencies. ${ }^{209}$ Likewise, if the amount of available budget authority is to be reduced by sequestration, that process should begin early in the fiscal year. Accordingly, GRH provides that calculation and apportionment of sequestration amounts will be largely completed before the fiscal year begins.

There are two significant dates in preparing for Stage Two, which the 1987 anendments to GRH term "snapshot" dates. These are the two dates which $\mathrm{CBO}$ and $\mathrm{OMB}$ use for calculating the projected deficit excess and amount of required sequestration. The first "snapshot" date occurs more than a month before the start of the fiscal year. ${ }^{210}$ Five days later CBO reports its calculations and five days after that OMB issues an equivalent report, which must account for any deviations from the $C B O$ report. $^{211}$ On the same day the President must issue his initial sequestration order, based on OMB's report. ${ }^{212}$ If, by the second "snapshot" date-shortly after the start of the new fiscal year ${ }^{213}$ - the traditional budget process has failed to produce tax, appropriation, and reconciliation legislation that brings the deficit within GRH's prescribed maximuin, then CBO issues another advisory report. Five days later, OMB issues a final sequestration report, again accounting for any deviations from CBO's report. ${ }^{214}$ This report becomes the basis for a final presidential order, issued fifteen days after the start of the fiscal year, that seques-

209. See supra notes 107-14 and accompanying text.

210. The first "snapshot" date is August 15 (or October 20, 1987, in the case of FY 1988). GRH 1987, supra note 24, § 102(a), 2 U.S.C.A. $§ 901(a)(3)(A)(i i)$ (West Supp. 1987).

211. Id. $\S 102(a), 2$ U.S.C. $\S 901(a)(2)(b)$ (West Supp. 1987) (amending GRH 1985, supra notc $10, \S 251(a)(2))$. Under the first version of $\mathrm{GRH}, \mathrm{CBO}$ and $\mathrm{OMB}$ issued one joint report, averaging any differences between them; the Comptroller General then accounted for any differences between this joint report and his final report. GRH 1985, supra note 10, $\$ 251$ (a), 2 U.S.C. $\S$ 901(a) (Supp. IV 1986) (amended 1987). Under GRH as amended in 1987, CBO's sequestration reports are advisory; they provide " $a$ benchmark against which Congress and others may assess the OMB reports." Initial Sequestration Report FY 1988, supra note 208, at 39,416.

212. GRH 1987, supra note $24, \S 102$ (a), 2 U.S.C.A. $\S 902$ (a)(1) (West Supp. 1987).

213. The seeond "snapshot" date is "the latest possible date before" October 10 (November 15 , 1987, in the case of FY 1988). Id. 2 U.S.C.A. $\$ \S 901$ (a)(3)(A)(ii), 901(c)(1) (West Supp. 1987); see also infra note 377 and accompanying text.

214. Id. $\S 102(a), 2$ U.S.C.A. $\S 901$ (c)(2) (West. Supp. 1987) (amending GRH 1985, supra note $10, \S 251(c)(2))$. 
ters budget authority. ${ }^{215}$ Both the initial and the final presidential sequestration orders must be fully consistent with OMB's calculations. ${ }^{216}$

The deficit estimates in the sequestration reports are not intended to be actual forecasts. ${ }^{217}$ Rather, CBO and OMB assume the continuation of "current" law, adjusted for inflation, as of each snapshot date in estimating the spending baseline and deficit excess. They do not consider proposed appropriations, tax measures, or reconciliation bills. ${ }^{218}$ In this way, the sequestration process can move forward even if Congress does not make timely progress on the annual budget in the traditional legislative budget process. If OMB determines that sequestration is necessary, the President's sequestration order makes spending reductions from whatever levels of budget authority Congress eventually appropriates for the sequestration year. ${ }^{219}$

Thus far, presidential sequestration orders have been issued in two fiscal years: first, beginning March 1, 1986, shortly after GRH was originally enacted; ${ }^{220}$ and second, beginning November 20,1987 , shortly after GRH was amended. ${ }^{221}$ In each year, Congress and the President were unable to enact a budget that would meet the deficit limitation set in GRH. A special provision in GRH linited the inaximum sequestration

215. Id. $\$ 102(a), 2$ U.S.C.A. $\$$ 902(b)(1) (West Supp. 1987) (amending GRH 1985, supra note $10, \S 252(b)(1))$. The timetable is later for FY 1988 because the 1987 amendments to GRH were enacted two days before the fiscal year began.

216. The President "may not modify or recalculate any of the estimates, determinations, specifications, bases, amounts, or percentages set forth" in the OMB reports. Id. $\S 102(\mathrm{a}), 2$ U.S.C.A. $\$$ 902(a)(2) (West Supp. 1987).

217. The sequestration deficit estimates may be contrasted with certain estimates prepared by $\mathrm{CBO}$ and $\mathrm{OMB}$ during the legislative budget process, which are more like forecasts. See Initial Sequestration Report for Fiscal Year 1987: Hearing Before the Temporary Joint Comm. on Deficit Reduction, 99th Cong., 2d Sess. 7-13 (1986) (statement of Rudolph Penner, Director, CBO, explaining differences in estimates); see also BUDGET OF THE UNITED STATES FOR FY 1989, supra note 4, at A-1, (discussing "current services" estimates required under Congressional Budget Act of 1974).

218. GRH 1987, supra note 24, §102(a), 2 U.S.C.A. $\S 901(a)(6)(A)$ (West Supp. 1987) (amending GRH 1985, supra note 10, $\S 251(\mathrm{a})(6)(\mathrm{A})$ ) (specifying "budget baseline" to be used by $\mathrm{CBO}$ and $\mathrm{OMB}$ in estimating the deficit excess and net deficit reduction required).

219. See id. $\S 102($ b), 2 U.S.C.A. $\S 902$ (f)(2)(B) (West Supp. 1987).

220. Emergency Deficit Control Measures for Fiscal Year 1986, 3 C.F.R. 254 (1986) (Presidential Order of Feb. 1, 1986, providing for sequestration beginning on Mar. 1, 1986). After Bowsher v. Synar, 106 S. Ct. 3181 (1986), struck down the FY 1986 sequestration, Congress quickly moved to enact the sequestration into law. See Act of July 31, 1986, Pub. L. No. 99-366, 1986 U.S. CODE Cong. \& ADM1N. NEws (100 Stat.) 773.

221. Emergency Deficit Control Measures for Fiscal Year 1988, 52 Fed. Reg. 44,960 (1987) (Presidential Order of Nov. 20, 1987, providing for sequestration beginning on November 20, 1987). The FY 1988 sequestration was repealed one month later when Congress finally passed and the President signed FY 1988 reconciliation legislation, Omnibus Reconciliation Act of 1987, Pub. L. No. 100-203, 1987 U.S. CODE \& ADMIN. NEws (101 Stat.) 1330, and omnibus appropriations, Act of Dec. 22, 1987, Pub. L. No. 100-202, 1987 U.S. CODE \& ADMIN. NEwS (101 Stat.) 1329. 
for FY 1986 to $\$ 11.7$ billion, ${ }^{222}$ even though this meant that the deficit would exceed GRH's stated maximum of $\$ 172$ billion. ${ }^{223}$ A similar provision in the 1987 amendments limited the total sequestration for FY 1988 to $\$ 23$ billion, ${ }^{224}$ regardless of whether this would achieve GRH's ostensible deficit maximum of $\$ 144$ billion. ${ }^{225}$ The 1987 amendments to $\mathrm{GRH}$ also provided that the spending baseline for determining sequestration should include increases for inflation. ${ }^{226}$ Since this adjustment was over $\$ 11$ billion for FY $1988,{ }^{227}$ the nominal $\$ 23$ billion sequestration in FY 1988 was actually about the same as the FY 1986 sequestrationapproximately $\$ 12$ billion less than "current" law not adjusted for inflation.

\section{b. Sequestration Rules}

While the primary strategy of GRH is to shield implementation of sequestration from the legislative process, ${ }^{228}$ a secondary strategic objective is to erect this shield without giving the President new impoundment authority or increased discretion over federal spending. ${ }^{22}$ GRH therefore prescribes formulae for allocating the spending cuts required to eliminate the deficit excess. ${ }^{230}$ While the 1987 amendments of GRH

222. GRH 1985, supra note 10, § 251(a)(3)(A)(ii)(II), 2 U.S.C. § 901(a)(3)(A)(ii)(II) (Supp. IV 1986).

223. Id. § 201(a)(7)(A), 2 U.S.C. $\S 622(7)(A)$ (Supp. IV 1986).

224. See supra note 201 and accompanying text.

225. GRH 1985 had originally prescribed a deficit maximum of $\$ 108$ billion for FY 1988. See supra text accompanying note 200 .

226. GRH 1987, supra note $24, \S 102$ (a), 2 U.S.C.A. $\S 901$ (a)(6)(C)-901(a)(6)(D) (West Supp. 1987) (amending GRH 1985, supra note 10, § 251(a)(6)(C)-251(a)(6)(D)).

227. See Initial Sequestration Report FY 1988, supra note 208, at 39,419.

228. As Sen. Hollings, a sponsor of GRH, stated:

We have tried several ways to win the discipline of both Houses, of both parties, at both ends of Pennsylvania Avenue, and the fact is that with all this so-called great leadership and wonderful Congress and wonderful executive branch and everything else, the national debt is about to exceed the numbing figure of $\$ 2$ trillion. That, to me, is the most convincing argument that the discipline needed to make the budget process work is simply not there.

131 CoNG. REC. S12,084 (daily ed. Sept. 25, 1985); see also id. at S12,572 (daily ed. Oct. 3, 1985) (statement of Sen. Rudman that "when Jefferson and Mạdison talked about checks and balances, they did not realize that there was a safety valve called the deficit and ... that Congress and the administration could fail in addressing basic policy and pour it all into the deficit").

229. For example, Sen. Gramm explained:

Let me make note of . . why this is significantly different than impoundment, and why it is significantly different than any line-item veto approach. We all know that the difficulties in those procedures are that Members of Congress are jealous of their powers, and they do not want to transfer power to the executive branch. The executive branch likewise does not want to pass power to the Congress. This bill does not create new powers.

Id. at $\mathrm{S} 12,568$ (daily ed. Oct. 3, 1985).

230. See The.Balanced Budget and Emergency Deficit Control Act of 1985: Hearing on H.J. Res. 372 Before a Subcomm. of the House Comm. on Government Operations, 99th Cong., 1st Sess. 69 (1985) (statement of James Miller, Director, OMB): 
grant OMB, rather than the Comptroller General, final authority over calculation of sequestration amounts, OMB must follow the statutory estimation and allocation formulae. These formulae are designed to achieve the requisite spending reduction regardless of the types of and total amount of extant spending authority.

The sequestration rules in GRH mirror the politics of the legislative budget. In order to garner wide legislative support and to make the threat of sequestration credible, GRH takes half of its spending cuts from the domestic budget and half from the defense budget. ${ }^{231}$ Moreover, GRH wholly or partially exempts pohtically sensitive or untouchable programs. As originally enacted in 1985, GRH exempted most annually appropriated and all permanently appropriated entitlement programs, ${ }^{232}$ including social security. ${ }^{233}$ As the legislation now stands, it appears to exempt, wholly or partially, every federal entitlement program, whether permanently or annually appropriated. ${ }^{234}$ In addition, GRH exempts obligated balances of budget autlority" ${ }^{235}$ and a long list of "prior legal obligations," 236 most of which are preexisting unliquidated contractual obligations of the federal government.

For every nonexempted budget account in the federal government, GRH requires that annual outlays be cut on a "uniform percentage

Even in the event of sequestering of funds, the President's function is essentially ministerial, that is, imposing uniform percentage spending reductions . . . across inost of the budget. Thus, [GRH] is entirely different from the line-item veto where the President would indeed have the power to pick and choose among prograins.

231. GRH 1985, supra note 10, $\$ 251$ (a)(3)(B), 2 U.S.C. $\$ 901(a)(3)(B)$ (Supp. IV 1986). The 1987 amendınents did not change this rule. GRH 1987, supra note 24, § 102(a), 2 U.S.C.A. $\S 901(a)(3)(B)$ (West Supp. 1987).

Sen. Bingaman (D. N.M.) described the political situation that produced this compromise:

Serious deficit reduction has been stalled by what iny colleague, Senator Pete Domenici, calls political gridlock. Everyone wants to cut the deficit, but inost are only willing to do so while exenpting their particular pet concerus. The President wants no new taxes and wants the defense budget spared. The House wants to hold the line on spending cuts for doinestic programs. ... And neither the President nor the Congress has shown a willingness to restrain the growth of Social Seeurity benefits to the same extent as other benefit programs.

131 CONG. REC. S14,603 (daily ed. Nov. 1, 1985).

232. GRH 1985, supra note $10, \S 255,2$ U.S.C. $\S 905$ (Supp. IV 1986); see generally supra notes 87-93 and accompanying text.

233. Id. § 255(a), 2 U.S.C. § 905(a) (Supp. IV 1986).

234. The 1985 version of GRH exeinpted the major entitlement programs, including inany annually appropriated prograins. See id. $\S 255(\mathrm{~g})(\mathrm{l}), 2$ U.S.C. $\S 905(\mathrm{~g})(1)$ (Supp. IV 1986) (complete exeinption for over thirty nained prograins). The 1987 amendinents to GRH list additional exeinpted prograins. See GRH 1987, supra note 24, § 104, 2 U.S.C.A. \$§ 905-907 (West Supp. 1987) (listing "exempt programs and activities," including programs not exempted under GRH 1985).

235. GRH 1987, supra note 24, § 102b, 2 U.S.C.A. $\S 906(l)$ (West Supp. 1987) (annending GRH 1985 , supra note 10, § 256(I)); see Initial Sequestration Report FY 1988, supra note 208, at 39,425 \& Table 6, at 39,427 (1987).

236. GRH 1987, supra note 24, § 104(c), 2 U.S.C.A. § 905(g)(2) (West Supp. 1987) (amending GRH 1985, supra note $10, \S 90 \$(\mathrm{~g})(2))$. 
basis."237 Sequestration thus uniformly reduces the amount spent in each part of the nonexempt budget. Although this umiformity rule, as well as GRH's other formulae, are stated in terms of outlays, sequestration ultimately cancels budget authority. ${ }^{238}$ Hence, OMB must both determine the outlay reduction percentages (one for the domestic budget and another for the defense budget) necessary to eliminate the deficit excess, and specify the exact amount of budget authority to be sequestered in each account. ${ }^{239}$ Moreover, GRH requires that the President's sequestration order apply the appropriate uniform percentage to every "program, project, and activity" within each budget account-again, one percentage for the defense budget and another for the domestic budget. ${ }^{240} \mathrm{GRH}$ permits future Congresses to define "program, project, and activity" in appropriations acts and accompanying committee reports. $^{241}$

Because the President's sequestration order must prescribe the amount sequestered for all "programs, projects and activities," it contains more "line-itemization" than appropriations acts typically do. As discussed previously, appropriations are generally at the level of a budget account, and each budget account may encompass many different programs. $^{242}$ If the uniformity requirement apphed only to accounts, then total sequestrable funds in each account would be reduced by the same percentage, but programs, projects, and activities within each account could be cut by varying percentages; some could even be eliminated altogether. The "program, project, and activity" rule implements the principle of uniformity within budget accounts as well as among accounts. ${ }^{243}$

The purpose of "uniform" reductions is to ensure that sequestration will not alter the relative spending priorities established by Congress. As Senator Gramm stated when he introduced GRH in the Senate in 1985: "What this bill does is simply make[] the President the instrument of the will of Congress in sequestering across the board proportionately so as to

237. Id. § 102(a), 2 U.S.C.A. § 901(a)(3)(E)(i) (West Supp. 1987).

238. GRH uses the term budgetary "resource" rather than budget "authority" even though budgetary "resources" consist primarily of the various forms of budget authority. The 1987 amendments define "sequestrable resource" as "new budget authority; unobligated balances; new loan guarantee commitments or limitations; new direct loan obligations, commitments, or limitations; spending authority [entitlements] ...; and obligation limitations for budget accounts, programs, projects, and activities that are not exempt from reduction or sequestration under this part." GRH 1987, supra note 24, § 102(b)(5), 2 U.S.C.A. § 907(9) (West Supp. 1987).

239. GRH 1987, supra note 24, $\S 102(a), 2$ U.S.C.A. $\$$ 902(a)(1)(B)(i) (West Supp. 1987); see also Initial Sequestration Report FY 1988, supra note 208, at 39,428 \& Table 7 at 39,429.

240. GRH 1987, supra note 24, § 102(a), 2 U.S.C.A. § 902(a)(1)(B)(i) (West Supp. 1987).

241. Id. This provision is discussed further infra text accompanying notes 303-31.

242. See supra note 122 and accompanying text.

243. The ambiguities and potential significance of the "program, project, and activity" uniformity requirement are discussed infra text accompanying notes 296-304. 
preserve the congressional intent in terms of priorities."244 Stated another way, the sequestration formulae prescribed by GRH require the President to spread the pain of spending cuts evenly among those parts of the budget that GRH neither fully nor partially exempts.

III

\section{Interstrtial Changes in the Constitutional Budget PROCESS}

GRH does not simply superimpose a new framework on the fiscal processes that had previously evolved. It actually alters traditional premises and procedures in each of three inportant areas in which the written Constitution is silent: (a) development of the federal budget; (b) the relationship between a legislative grant of spending authority and the actual funding process; and (c) the specificity of appropriations legislation. $^{245}$

The traditional budget process yielded a unified "budget" only after the fact; it treated revenues as neither a procedural nor a substantive limitation on spending legislation. For two hundred years, that process has produced spending legislation responsive to the politics of the electorate. Although in modern times this legislation lias created large federal deficits, the annual deficit has never before formally limited congressional appropriations or other spending autliority. GRH turns the traditional legislative budget process on its head by prescribing a deficit inaximuin (or deficit excess). Under GRH, a specific outcome - set by the deficit inaximuin - becomes the substantive and procedural focus of the legislative process. From this outcoine, Congress and the President must work backward to derive acceptable spending and revenue legislation. The first Section below explores the consequences of such deficitdriven legislation.

A second way in which GRH fundamentally alters the traditional spending process is by increasing the significance of the relationship between budget authority and outlays. Before GRH, once Congress appropriated a certain amount of budget authority to an agency, it did not matter when the agency spent the money. ${ }^{246}$ Under GRH, however, the rate at which an agency's appropriations actually becoine "outlays" is of central concern. In the event of sequestration, the ratio between

244. 131 CONG. REC. S12,568 (daily ed. Oct. 3, 1985) (statement of Sen. Gramm).

245. The historical evolution of fiscal processes in each of these three areas prior to GRH is explored in Part I, supra pp. 599-621.

246. The timing of obligations has always been important, since unost budget authority eventually expires if not used, usually after one fiscal year. See 31 U.S.C. $\$ 1502$ (1982). Moreover, the Anti-Deficiency Act requires agencies to apportion budget authority obligations throughout the fiscal year so as to avoid coercive deficiencies. See 31 U.S.C. $\S 1512$ (1982). The timing of subsequent outlays, however, had no particular legal significance prior to GRH. 
budget authority and outlays for each budget account determines the amount by which an account's legislated budget authority will be reduced. The second Section below examines how the relationship between an agency's obhigational authority and its outlays becomes critical to achieving the prescribed deficit target and "uniformity" in sequestration.

A third aspect of our budget process that GRH alters is the legal significance of line itemization by Congress. By the middle of the 20th century, the traditional budget process relied upon lump-sum appropriations, which allowed the executive branch significant discretion in allocating funds among activities im each account. As the third Section below explains, GRH invites greater legislative participation in the allocation of appropriations within accounts.

\section{A. A Deficit-Driven Legislative Process}

Under GRH, the deficit assumes primacy over all other ineasures of fiscal health. Never before has legislation prescribed an overarching, substantive fiscal mandate for the legislative budget process that is enforced outside that process. GRH makes the deficit the substantive and procedural touchstone of the entire budget process: the President must propose a budget that meets GRH's deficit limitation; Congress must conform to the "deficit neutrality" requirenent; ${ }^{247}$ and, most importantly, if the President and Congress fail to achieve GRH's prescribed deficit reduction, sequestration takes place automatically.

Although GRH made deficits the focus of budgeting as a matter of law, the deficit was of central political concern prior to GRH. Indeed, political unease about the deficit, which intensified as deficits grew during the 1970s and early 1980s, may have made GRH-or similar dramatic framework legislation-inevitable. ${ }^{248}$ President Reagan was elected in 1980 on a platform promising, among other things, elimination of the deficit by reducing federal spending. Walter Mondale was defeated in 1984 partly because of his promise to reduce the deficit by increasing federal taxes. ${ }^{249}$ Even before GRH, the deficit was considered by inany to be a measure of the success or failure of the federal budget.

The procedural changes introduced in the Congressional Budget Act of 1974 encouraged this growing preoccupation with budget deficits.

247. See supra text accompanying note 197.

248. See, e.g., Majority in Poll Look to Congress to Cut Spending, N.Y. Times, Nov. 17, 1985, $\S 1$, at 1 , col. 3 ( $28 \%$ of those polled thought deficit was worst of five political problems presented); Voters Found Doubtful of ' 86 Deficit Decline, id. Sept. 8, 1985, at A1, col. 1 (poll showing widespread doubt that deficit would decline and showing support for balanced budget constitutional amendment).

249. See 24 TAX Notes 1101-03 (1984) (discussion of political and fiscal consequences of candidate's tax increase proposal). 
The 1974 legislation and the move to "reconciliation" in $1981^{250}$ were in some important respects precursors of GRH; hike GRH, they may be interpreted as attempts to restrain Congress and the President from increasing spending disproportionately to revenues and without regard to competing program needs. Nonetheless, under the 1974 legislation, the deficit was simply one of several nonbimding fiscal aggregates that Congress resolved to meet each year, and it was a dependent variable derived from spending and revenue aggregates. ${ }^{251}$

GRH, of course, prescribes a deficit maximum that Congress must meet each year. Yet $\mathrm{m}$ an arithmetic sense, the deficit remains formally a dependent variable. In order to calculate the deficit, it is necessary to estimate both revenues and outlays, ${ }^{252}$ because the deficit is the amount of net outlays in any given fiscal year. Yet, Congress contimues to appropriate (and otherwise enact spending legislation) in the currency of budget authority. Hence, the relationship between budget authority and outlays becomes critical; whether sequestration is avoided depends not only on how much budget authority Congress appropriates, but also on the expected level of outlays. There are significant opportunities in the legislative process to underestimate or change the projected timing of budget outlays, ${ }^{253}$ and GRH may well mcrease incentives to manipulate outlay projections.

Two types of information are needed to estimate outlays: (1) the baseline amount of budget authority; and (2) the outlay rate, which is the rate at which budget authority is expended. ${ }^{254}$ The outlay rate is neces-

250. See supra notes $172-76$ and accompanying text.

251. Under the Congressional Budget Act of 1974, the five aggregates in the annual budget resolution were new budget authority, outlays, revenues, the deficit, and the public debt, §301(a), 88 Stat. 306. These aggregates were not binding, see supra notes 154-163.

252. Other commentators have noted the difficulties of forecasting revenues, which depend greatly upon assumptions about economic growth and inflation. See, e.g., S. COLLENDER, supra note 94, at 7; Elliott, supra note 191, at 357-58 ("[P]rojections of future governmental revenues are indefinite and highly sensitive to assumptions made about the future health of the economy ...."); Gettinger, Reagan's Deficit Projections Too Low, CBO Tells Congress, 44 CoNG. Q. WEEKLy REP. 493 (1986) (quoting CBO Director Penner as saying, "[t]he law is totally dependent on forecasts and estimates"); see also Synar v. United States, 626 F. Supp. 1374, 1387-89 (D.D.C. 1986) (3-judge court) (per curiam) (GRH delegates significant discretion regarding deficit estimate), affd sub nom. Bowsher v. Synar, $106 \mathrm{~S}$. Ct. 3181 (1986). I focus on a less explored phenomenon: the difficulty of estiniating olttlays in both the "controllable" and "uncontrollable" budgets. See supra notes 101-02 and accompanying text.

253. See D. Stockman, supra note 187 , at $165-66$ \& 194 note; Greider, supra note 18 , at 38 (congressional budget resolution as "a series of gimmicks," "economic estimates," "accounting tricks," and "political numbers").

254. I use the term "outlay rate" to include all aspects of the timing of outlays, while GRH uses the term more normally. See GRH 1987, supra note 24, § 102(b)(8), 2 U.S.C.A. § 907(13) (West Supp. 1987) (amending GRH 1985, supra note 10, § 257) (defining "outlay rate"). What GRH refers to as an "outlay rate" is largely encompassed by the term "spend-out rate." See Impact of the Gramm-Rudman-Hollings Law: Hearings Before a Subcomm. of the House Comm. on Government Operations, 99th Cong., 2d Sess. 63 (1986) [hereinafter House Comm. on Government Operations 
sarily only an estimate. For any given account or program, the annual outlay rate depends on the amount that is actually expended during the year. In many programs, especially those tied to the state of the economy, estimates of outlay rates are highly responsive to assumptions about GNP growth, inflation, and what budget analysts refer to as "technical" assumptions regarding program utilization. ${ }^{255}$ Additionally, outlay rates vary among programs, among different types of budget authority, and among different items of expenditure withm a program. During Stage One, the most important numbers in the congressional budget resolution are not the amounts of new budget authority allocated to various programs, but the accompanying estimates of outlays, calculated on the basis of outlay rates.

GRH does not impose on the budget process as a whole a uniform baseline and methodology for estimating budget authority and outlays. Prior to GRH, the President had used one approach in his budget proposals, ${ }^{256}$ and Congress had used another in the congressional budget resolution. ${ }^{257}$ The original GRH chose yet a tlird way to estimate baseline budget authority, ${ }^{258}$ and the statute's directions left significant discretion to those implementing this procedure. Indeed, in estimating the deficit and calculating sequestration amounts, the Comptroller General simply used the average of the disparate estimates of gross outlays made by the $\mathrm{CBO}$ and $\mathrm{OMB}$ in their joint sequestration report, as Congress probably anticipated he would. ${ }^{259}$

The 1987 amendments to GRH do much to encourage coherence

Hearings] (question of Rep. J. Brooks to Rudolph Penner, Director, CBO, asking whether "spendout rates" have changed as a result of sequestration); Balanced Budget Act: Gramm-Rudman: Hearings Before the House Comm. on Energy and Commerce, 99th Cong., 2d Sess. 55-57 (1986) [hereinafter House Comm. on Energy and Commerce Hearings] (testimony of Rudolph Penner, Director, CBO, and Charles Bowsher, Comptroller General, concerning calculation of spend-out rates).

255. For instance, in federal credit programs, varying assumptions about the timing of foreclosures will alter the timing-outlay rate - of outlays in any given year. See generally Congressional Budget Office, Congress of the United States, AN ANalysis of the President's Budget Proposals for FisCal Year 1989 21, $24-26$ (1988) (explaining significance of technical assumptions pertaining to outlays).

256. See Budget of THE United States Government FY 1989, supra note 4, A-14 to -19 (explaining difference between estimates in President's proposed budget and estimates using "current services" approach required by Congressional Budget Act of 1974).

257. See Staff of House Comm. ON the Budget, 100TH CONG., 1st Sess., President Reagan's Fiscal Year 1988 Budget 4 (Comm. Print 1987).

258. GRH 1985, supra note 10, § 251(b), 2 U.S.C. $\$ 901$ (b) (Supp. IV 1986) (amended 1987). This baseline concept of spending was referred to as the "Gradison" baseline, since it was proposed by Congressinan Willis Gradison. See Office of Management and Budget, Gramm-RudmanHollings Briefing Materials 4 (Aug. 15, 1986) (unpublished manuscript on file with author).

259. See Comptroller General of the United States, Budget Reductions for FisCal YeaR 1986, H.R. Doc. No. 155, 99th Cong., 2d Sess. (1986) (accepting almost all calculations in CBO/OMB Sequestration Report for FY 1986, 51 Fed. Reg. 1917 (1986)). 
and consistency in baseline estimates and methodology, but they do not resolve the larger sources of imprecision inherent in estimating outlays. GRH now requires that the President's proposed budget, ${ }^{260}$ OMB's sequestration reports, and the presidential sequestration order all use the same baseline level of budget authority from which to estimate outlays. ${ }^{261}$ That basehine spending level is, essentially, budget authority of the current year adjusted to account for inflation in the cost of real goods, benefits, and services, and further adjusted to account for clianges in the number of eligible recipients of various entitlement programs. ${ }^{262}$

Even with a uniform system for determining baseline budget autliority, estimates of annual outlays in each part of the budget will vary depending on technical assumptions and the metlod used to estimate outlay rates. Beyond the inherent potential for error in estimates, Congress may manipulate outlay estimates in order to "meet" GRH's requirenents; Congress could deflate the projected deficit by arbitrarily lowering an estimate of outlays, even when the level of budget authority in fact implied a higher outlay level. Witl respect to defense spending, for example, the congressional budget resolution in the first year of GRH arbitrarily paired the (liiglier) Senate level for budget autliority with the (lower) House level for outlays. ${ }^{263}$ There were also claims that OMB deliberately underestimated outlay rates im order to offset its proposed

260. The President's proposed budget contains estimates of new, unobligated, and obligated budget authority and of expected annual outlays for each budget account. See BUDGET OF THE UNITED STATES GOVERNMENT FY 1989, supra note 4, at Appendix.

261. GRH 1987, supra note $24, \S 102$ (a), 2 U.S.C.A. $\S 901$ (a)(6) (West Supp. 1987); see also id., $\S 106(f), 1987$ U.S. CODE CONG. \& ADMIN. News (101 Stat.) 781 (to be codified at 31 U.S.C. $\S 1105(f)(3))$. In signing the 1987 amendments to GRH, President Reagan questioned the constitutionality of this requirement as it pertains to his proposed budget each year: "In light of the President's plenary power under Article II, sec. 3 of the Constitution to submit to the Congress any legislation he deems necessary and expedient, this provision must be viewed as merely precatory." Federal Debt Limit and Deficit Reduction Bill, 23 WEEKLy CoMP. Pres. Doc. 1091 (Oct. 5, 1987). It is not clear what force, if any, such presidential interpretations have or are intended to have. See Strasser, Executive Intent, 18 NaT'L J. 2 (March 10, 1986); Note, Let Me Tell You What You Mean: An Analysis of Presidential Signing Statements, 21 GA. L. REv. 755 (1987). In any event, this particular objection is quite curious because both the requirement that the President subinit a budget, see supra notes 51-57 and acconpanying text (discussion of the Budget and Accounting Act of 1921), and GRH's general requirement that the President's proposed budget neet the GRH deficit targets, would seem more important than which spending baseline the President should use. In any event, the constitutional objection is not well-founded. The President, of course, has power under the Constitution to submit to Congress any legislation he desires, but this does not negate Congress' concurrent power, under the necessary and proper clause of art. I, $\S 8$, to require the President to subinit certain types of legislation in addition to that which he may independently desire to subinit.

262. See supra notes $217-18$ and accompanying text.

263. See Dividing the Difference on Funding, 44 CONG. Q. WEEXLY REP. 2337 (1986). This manipulation of outlay estinates apparently was initially agreed to prior to enactınent of GRH. See also Wehr, Senate Adopts Democrats' Fiscal 1988 Budget, 45 CONG. Q. WEexLY REP. 890, 891(1987) (noting that pairing outlays and budget authority simply to satisfy conficting demands "badly skew[s]" the budget figures). 
increases in budget authority. ${ }^{264}$ The FY 1987 budget came within $\$ 10$ billion of GRH's deficit requirement by attributing $\$ 10$ billion of FY 1987 outlays to FY 1986 and to FY $1988 .{ }^{265}$ Congress achieved another $\$ 6$ billion in deficit reduction by authorizing the sale of government loan assets and of Conrail. ${ }^{266}$ This tactic simply traded federal assets for cash, thereby reducing the annual cash-flow deficit but also eliminating the future incoine from these assets.

The 1987 amendinents to GRH attempt to reduce the possibility of distorted estimates by prohibiting certain asset sales and changes in outlay attribution from being counted as outlay reductions for purposes of deficit estimates under GRH. ${ }^{267}$ Additionally, in order to discourage inampulation of outlay estimates in favor of or against certain programs, the 1987 amendments require OMB to use the same outlay rate assumptions in any one year as it used in its sequestration reports for the previous year. ${ }^{268}$

While the 1987 amendinents reffect a laudable legislative effort to do inore than merely reduce the aimual cash-flow deficit, they have not eliminated inamipulation of budget authority/outlay ratios. ${ }^{269}$ More importantly, whether estimated pursuant to the original version of GRH

264. See house COMmittee ON Government Operations, 100Th CONG., 15T SEsS., Reform of the federal budget Process: An ANalysis of Major Proposals 13 (Comm. Print 1987).

265. For example, a military payday was moved from September 30, 1987 to October 1, 1987, resulting in a $\$ 2.9$ billiou savings in FY 1987. See Dividing the Difference on Funding, supra note 263. Reconciliation legislation for FY 1987 accelerated revenue collections froin FY 1988 to FY 1987 in order to ineet GRH's target. Omnibus Budget Reconciliation Act of 1986, Pub. L. No. 99 . 509, 1986 U.S. CODE CONG. AND ADMIN. News (100 Stat.) 1184. Other spending was attributed to FY 1986. See generally Wehr, Gramm-Rudman Both Disappoints and Succeeds, 44 CoNG. Q. WEEKLY REP. 2879, 2880-81 (1986).

266. See Major Provisions of the Fiscal 1987 Reconciliation Bill, 44 CoNG. Q. WEExLY REP. 2790, 2791 (1986). Reconciliation legislation for FY 1987, Pub. L. No. 99-509, directed the Secretary of Transportation to sell Conrail, the government-owned freight railroad, through a public stock offering. The sale was accomplisled in FY 1987. The FY 1987 reconcihation bill also provided for the sale of federal loan portfolios for rural development, rural housing, and prepayment of Export-Import Bank loans to foreign governments. Id.

267. Except as otherwise provided ... any law or regulation that has the effect of transferring an outlay, receipt, or reveuue of the United States from one fiscal year to an adjacent fiscal year slall not be treated as altering the deficit or producing net deficit reduction in any fiscal year for purposes of the Congressional Budget Act of 1974 and the Balanced Budget and Emergency Deficit Control Act of 1985.

GRH 1987, supra note 24, § 202(a), 2 U.S.C.A. § 909(a) (West. Supp. 1987); see also id. § 102(a), 2 U.S.C.A. $\S$ 901(a)(6)(I) \& 901(a)(6)(K) (West Supp. 1987); H.R. CoNF. REP. No. 313, 100th Cong., 1st Sess. 54, reprinted in 1987 U.S. CoDE Cong. \& ADMIN. NEws 739, 754; Initial Sequestration Report FY 1988, supra note 208, at 39,419-20.

268. See GRH 1987, supra note 24, § 202(a), 2 U.S.C.A. $\S 909$ (a) (West Supp. 1987); id. $\S 102(a), 2$ U.S.C.A $\S$ 901(a)(6)(I) \& 901(a)(6)(K) (West Supp. 1987); H.R. CoNF. REP. No. 313, supra note 267, at 52; see also Welir, Senate Accepts Gramm-Rudman Modification, 45 CoNG. Q. WEEXLY REP. 1719 (1987).

269. See Rapp, Budget Panel Finds Little Room to Maneuver, 46 CONG. Q. WEEKLY REP. 628 (1988) (House of Representatives inay decide to match outlay maximums agreed to by the President 
or the 1987 version, the "deficit" is a concept of limited fiscal significance. Because the deficit is defined as annual net outlays, it merely expresses how much cash the government must borrow each year. Such cash-flow accounting is a "primitive" form of budgeting, even without congressional or admimistrative manipulation. ${ }^{270}$ Gross outlays reflect neither the amount of spending Congress annually authorizes nor the sum of new obligations annually assumed by the federal government. The annual outlays of any one year depend in large part on technical economic assumptions and the amount of previously enacted budget authority that is obligated. Because the cumulative outlay rate approaches $100 \%$ in the long run, ${ }^{271}$ the annual rate is virtually irrelevant for long-term fiscal planning.

GRH invests short-term outlay rates with greater significance than the long-term obligations that they liquidate. Thus, the legislation creates incentives to cut items with high outlay rates ${ }^{272}$ and to change outlay timing in budget estimates-"pushing" outlays into future years-especially since GRH's deficit requirements for future years can be (and have been) revised upward. ${ }^{273}$ GRH's enshrinement of deficits as the talisinan of budgetniaking ignores or rejects the lesson of a century of public administration that, in the long term, obligational authority is the ouly meaningful measure of legislative spending.

\section{B. The Relationship Between Spending Authority and Outlays Under Sequestration}

Just as GRH's focus on the deficit makes outlay estimates of critical importance in the legislative budget process, so also outlay estimates are critical in Stage Two-the sequestration process. As discussed in the preceding Section, the deficit is the measure of annual net outlays, and thus OMB's outlay estimates affect whether and to what extent sequestration will occur. In addition, because GRH requires "uniform" sequestration at the subaccount level, as well as the account level, outlay estiniates for each "item for which appropriations are made" in the donestic budget and for every "program, project, and activity" in the defense budget have legal significance. ${ }^{274}$

and congressional leaders with higher budget authority figures, in order to "give the Budget Committee more room to accommodate the competing requests for funds").

270. Nordhaus, The Imperfections of the Budget, N.Y. Times, Mar. 22, 1981, C2, col. 3; see also Murray, Government's System of Accounting Comes Under Rising Criticism: Its Emphasis on Cash Flows Favors Short-Term Ploys that Lift Eventual Costs, Wall St. J., Feb. 3, 1986, at 1, col. 6.

271. In other words, virtually all money Congress appropriates is in fact spent.

272. See 132 CoNG. REC. S5162 (daily ed. May 1, 1986) (statement of Sen. Stevens) (only way to meet low outlay requirement for defense may be to cut areas with high outlay rates that are critical to national security, such as readiness, operations and maintenance, and personnel).

273. See infra text accompanying notes $382-85$.

274. GRH 1985, supra note 10, § 251, 2 U.S.C. $\S 901$ (a)(4)(C) (Supp. IV 1986) (amended 1987); 
The sense in which GRH requires uniformity in sequestration is subtle and limited. The legislation prescribes that outlays from sequestrable budgetary resources be reduced by the same percentage across accounts and programs. ${ }^{275}$ Accounts and programs with the same total amount of budget authority will not necessarily lose the same percentage of budget authority, since the proportion of exempted (nonsequestrable) budget authority varies from account to account and among programs within an account. For example, in any given fiscal year, programs with a high proportion of obligated budget authority, which is exempt from sequestration, ${ }^{276}$ will have their total budget authority reduced by a smaller percentage than programs with little or no preexisting obligated authority. Of course, Congress would not have exempted some forms of budget authority had it desired uniform sequestration across the whole budget.

Additionally, even among accounts or programs with the same total amount of sequestrable budget authority, GRH's "umiform" sequestration will not reduce outlays equally im the sequestration year because outlay rates often vary. ${ }^{277}$ One source of variance is the composition of budget authority available in different accounts and programs. For example, any budget authority that expires at the end of the current year will probably have a higher outlay rate than authority that can be carried over into the next year. ${ }^{278}$ Conversely, budget authority carried over from the previous year will have a higher outlay rate than new budget

see id. $\S 257,2$ U.S.C. $\S 907$ (8) (Supp. IV 1986) ("The term 'account' means an item for which appropriations are made in any appropriation Act ... and, for items not provided for in appropriation Acts, such term means an item for which there is a designated budget account identification code number in the Appendix to the President's budget.").

275. GRH 1987, supra note 24, § 102(a), 2 U.S.C.A. \$ 901(a)(3)(E)(i) (West Supp. 1987); H.R. CONF. ReP. No. 433, 99th Cong., 1st sess. 79 (1985), reprinted in 1985 U.S. CODE CONG. \& ADMIN. News 988, 996; see also Initial Sequestration Report for FY 1988, supra note 208, at 49,428 $\&$ Table 7 at 39,429; Staff of House Comm. ON THE Budget, 99TH Cono., 15T Sess., The Congressional Budget Process: A General Explanation app. $\mathrm{c}$ at $97-99$ (Comm. Print 1985).

276. As originally enacted, GRH permitted sequestration of certain types of obligated balances in defense programs, provided that contract modifications were obtained. GRH 1985, supra note 10, $\S 251$ (d)(3), 2 U.S.C. $\S 901$ (d)(3) (Supp. IV 1986) (amended 1987). As amended in 1987, all obligated balances of budget authority are excluded from sequestration. GRH 1987, supra note 24 , § 102(b)(3), 2 U.S.C.A. § 906(I) (West Supp. 1987); see also H.R. CoNF. REP. No. 313, supra note 267, at 52, reprinted in 1987 U.S. CODE CONG. \& ADMIN. News at 752-53.

277. See House Comm. on Energy and Commerce Hearings, supra note 253, at 59-60 (Comptroller General Bowsher discussing variance in spend-out rates).

278. A related administrative practice, called "June buying" when the fiscal year began on July 1, occurred when program managers tried to obligate by June 30 about-to-expire budget authority. A. WiLDAvSKY, supra note 141, at 31 . Apparently the practice continues-now, with the fiscal year beginning on October 1, as "September buying." See September: The Rush to Spend, N.Y. Times, Oct. 1, 1987, at B6, col. 6 (detailing agency efforts to use up amoints remaining in budgets). Theoretically, however, agencies may not use annual appropriations for the needs of future years. See Principles, supra note 60, at 4-10 to -11 . 
authority. Outlay rates also vary among different types of expenditures. Budget authority for salaries has a high outlay rate since it is generally spent in the year it becomes available. ${ }^{279}$ On the other hand, budget authority for capital expenditures or long-term contracts that is obligated in the year it becomes available may not be converted to outlays until future years. ${ }^{280}$

Moreover, sequestration itself may induce changes in the timing of outlays which prevent achievement of "uniform" sequestration even in the limited sense that GRH seeks. GRH allows the executive branch to determine where, within each program or other "item" of appropriation, expenditure reductions will be made. As Coinptroller General Bowsher has noted, program inanagers have "coinplete flexibility" in deciding where cuts will be made at the subprogram, subproject, and subactivity level. ${ }^{281}$ Given this authority, prograin managers are likely to achieve the spending reduction prescribed in a sequestration order by selecting slower spending, less urgently needed iteins for reductions.

For a program inanager, sequestration is equivalent to a sudden reduction in appropriations as the fiscal year begins (or, in the case of FY 1986, when the fiscal year was almost half over). ${ }^{282}$ The agency submits its budget requests and justifications to $\mathrm{OMB}$ early in the previous fiscal year. It is not until August, however, when OMB issues its intial sequestration report, that the agency knows the potential sequestration reduction for each program (in the defense budget) and each account (in the doinestic budget). ${ }^{283}$ And, of course, the agency will not know whether or not sequestration will occur until just after the fiscal year begins. ${ }^{284}$ In order to minimize the imipact of sequestration on their budgets, prograin managers will likely forego items of future need to protect iteins of immediate need. They will eliminate expenditures and personnel support that would not be delivered until the next fiscal year in favor of items whose

279. The outlay rate will be highest for administrative accounts, both because Congress generally does not permit such authority to be carried over from year to year, and because such authority is spent the same year it is obligated. See generally BUDGET OF THE UNITED STATES GOVERNMENT FY 1989, supra note 4, at app. (for administrative accounts, ratio of outlays to budget authority is higher than for nonadministrative accounts).

280. See BUdGET OF THE UNITED STATES FOR FY 1989, supra note 4, at $6 \mathrm{e}-9$ to -10 (discussing "full funding" in the first year for major procurement programs and construction projects.)

281. Id. at 75 (colloquy between Comptroller General Bowsher and Rep. Dingell).

282. The fiscal year begins on October 1. However, the President's sequestration order for FY 1986 was issued on February 1, 1986, and went into effect on March 1 of that year. See Emergency Deficit Control Measures for Fiscal Year 1986, 3 C.F.R. 254 (1987).

283. See House Comm. on Energy and Commerce Hearings, supra note 254, at 73 (Comptroller General Bowsher conceding that the weakness of GRH is not knowing what sequestration will impose "until the fiscal year is upon you").

284. See supra note 215 and accompanying text (timing of final sequestration order). 
immediate delivery is more important. ${ }^{285}$ This response may create a "coercive deficiency" 286 necessitating supplemental appropriations later in the sequestration year.

In sliort, GRH's promise of uniformity is himited-due to variance in outlay rates among and within accounts and due to changes in outlay rates induced by sequestration itself. Furthermore, program managers are likely to increase the rate of outlays in response to the budget cuts that sequestration imposes. Of course, if OMB anticipates this effect in calculatimg outlay rates under GRH, it will avoid underestimating the amount of sequestration needed to achieve the outlay reduction GRH mandates in any given fiscal year. ${ }^{287}$ Unfortunately, the 1987 amendments to GRH may well mcrease the discrepancy between estimated and actual outlay rates. As previously noted, those amendments require that OMB assume particular historical outlay rates, ${ }^{288}$ even if those historical rates are maccurate. The result may be marginal undersequestration.

The only way to ensure that outlay rates do not change after sequestration and hence to ensure uniformity would be to require that all component parts of the (sequestrable) budget be reduced uniformly. Indeed, GRH's requirement of uniform reductions at the level of appropriation "item" and "program, project, and activity"289 represents a limited attempt to preserve presequestration outlay rates. But units of expenditure at the level of "program, project, and activity" are themselves composed of subparts-there is no irreducible atom of federal spending. It is not feasible for CBO, OMB, Congress, or anyone else to list every iten of federal expenditure and calculate a uniform, proportionate reduction in each. Yet, once discretion is given to allocate sequestration amounts among several items of expenditure, the outlay rate will change.

Importantly, Congress itself has encouraged nonuniform reductions at the subprogram level. The conference committee report on the original GRH urged that personnel not be laid off until other methods of reducing fiscal obligations had been exhausted. ${ }^{290} \mathrm{OMB}$ and CBO have likewise urged program managers "not to resort to personnel furloughs

285. See House Comm. on Energy and Commerce Hearings, supra note 254, at 119-21 (discussion of Nuclear Regulatory Commission's response to FY 1986 sequestration).

286. See supra note 108 and accompanying text.

287. In FY 1986, despite a lower than projected inflation rate, outlays exceeded the level estimated when sequestration went into effect. Most of this deviation appears to be due to erroneous "technical" and other assumptions about the timing of federal spending, with a small residual due to general speed-up of federal spending under sequestration. See BUDGET OF THE UNITED STATES GOVERNMENT FY 1989, supra note 4, at 6d-24 (explaining difference in outlay estimates between early 1986 and early 1987).

288. See supra text accompanying note 268.

289. See infra notes $296 \& 301$ and accompanying text.

290. See H.R. CoNf. REP. No. 433, supra note 275 , at 94 , reprinted in 1985 U.S. Code CoNG. \& ADMIN. NEwS at 1011-12. 
until other methods of achieving savings prove insufficient, such as reducing spending for travel, printing, supplies, and other services."291 It would appear, therefore, that neither Congress nor those implementing GRH anticipate completely uniforin reductions in outlays, even in the limited sense that the statute prescribes uniformity.

Even if OMB desired or was directed by Congress to maintain constant outlay rates under sequestration, it probably could not do so. Despite OMB's power under the Anti-Deficiency Act to apportion an agency's budget authority, ${ }^{292} \mathrm{OMB}$ is often unaware of how apportioninents are actually spent. Budget administration has been called the "dark continent" of the federal budget process. ${ }^{293}$ There are indications that administrative reprogrammings and impoundinents (failures to spend appropriations) routinely occur deep within agency bureaucracies as a result of management decisions that are not reported to Congress as required by reprogramming arrangements and the Impoundment Control Act-imdeed, changes in the timing and allocation of expenditures may not even be known to OMB. ${ }^{294}$

It is no criticism of $\mathrm{OMB}$ or others charged with inplementing GRH that they can neither estimate outlays at the subaccount level with certainty nor inaintain constant outlay rates after sequestration. Despite their best efforts, appropriations in the currency of budget authority do not translate easily into uniforin deficit reduction in the currency of outlays. The problem hes not in the competence of OMB or others, but in the deficit-driven structure of GRH.

\section{The Reemergence of "Line Itemization"}

As has been noted, ${ }^{295}$ an agency has discretion over allocation of its appropriations except where Congress statutorily requires a particular allocation. That is, the agency is bound only by the lump-sum amounts appropriated for each numbered budget account and any further earmarkings that appropriation acts specify. Since the New Deal, Congress has generally enacted broad, lump-sum appropriations, relying

291. Office of Management and Budget \& Congressional Budget Office, SEQUeSTRATION REPORT FOR FY 1986, 51 Fed. Reg. 1918, 1936 (1986). This plea illustrates the substantial leeway that program managers have in allocating the sequestration of their budget authority.

292. See supra text accompanying notes 117-19.

293. Oversight on the Impoundment Control Process: Hearing Before the Task Force on Enforcement, Credit, and Multiyear Budgeting of the House Comm. on the Budget, 97th Cong., 2d Sess. 180 (1982) [hereinafter Oversight on the Impoundment Control Process] (stateinent of Professor Allen Schick).

294. Id. at $171,179$.

295. See supra notes $129-37$ and accompanying text. 
upon nonbinding "reprogramming" agreements to restrain executive allocation anong the various activities within each lump sum.

It is possible that the President and OMB could seek to exploit sequestration in order to shift the existing balance of political power between the Congress and the executive in administration of federal programs. GRH attempts to prevent such a shift in power by expanding Congress' role in allocation of appropriations. GRH thus is an exception to the historical trend away from hine itemization and toward lump-suin appropriations. Although the new procedure established by GRH grants congressional appropriations cominittees limited authority to allocate sequestration reductions, the procedure appears to be constitutionally sound. In any event, the administering agency-not congressional coinmittees-typically retains the ultimate authority to allocate sequestration amounts within each statutory allocation.

\section{The Uniformity Requirement and Line Itemization}

GRH requires that in the event of sequestration, every budget account must be reduced uniformly. The statute defines budget "account" as including both the numbered entries in the President's annual budget proposal (the traditional definition of a budget account) and any further statutory allocations (earnarking) within each traditional budget account. ${ }^{296}$

By expanding the defimition of "account" to inake every statutory line item a separate "account," GRH invites increased legislative specification of appropriation amounts. The expanded definition allows Congress to transforin any item of expenditure into an "account" by earnarking funds for that item in an appropriations act. Since sequestration reductions must be uniforn for each of these "accounts," Congress can protect specific items from disproportionate sequestration by designating the appropriation for each. Hence the prospect of sequestration may encourage greater line itemization. Because it is statutory, this hine itemization is binding on the administering federal agency even if sequestration does not occur.

GRH is not the only recent legislation that encourages Congress to earmark appropriations more extensively. The Inpoundment Control Act, enacted in 1974 as part of the Congressional Budget and Inpoundment Control Act, ${ }^{297}$ created a similar incentive. Under that statute, the

296. GRH 1985, supra note 10, $\$ 257(8), 2$ U.S.C. $\$ 907(8)$ (Supp. IV 1986) ("The term 'account' means an item for which appropriations are made in any appropriation Act [or] an item for which there is a designated budget account identification code number in the Appendix to the President's budget.").

297. Pub. L. No. 93-344, tit. X, §§ 1001-1017, 88 Stat. 297, 332-339 (1974) (codified as amended at 2 U.S.C. $\S \S 681-688$ (1982 \& Supp. III 1985) and 2 U.S.C.A. $\S \S 683-697$ (West Supp. 1987)). 
President may permanently impound-refuse to spend--budget authority only if each House of Congress approves. ${ }^{298}$ However, the impoundment control legislation only regulates impoundment of funds from a budget account; it does not govern or even refer to the allocation of funds - within an account. If an agency simply allocates its lump-sum appropriation differently than proposed in its budget justification or the appropriation committee reports, its action does not constitute "impoundment." Simply put, reprogrammings are not impoundments. ${ }^{299}$ Statutory line itemization, then, is necessary for Congress to bring executive reallocations within the Inpoundment Control Act.

\section{The Significance of the "Program, Project, and Activity" Rule}

In addition to encouraging greater statutory line itemization of appropriations, GRH subtly changes the legal effect of appropriation coinmittee reports because it rehes on these reports to specify important details of sequestration.

GRH prohibits the elimination of any "program, project, or activity" by sequestration. ${ }^{300}$ It further requires that sequestration be umform, not only for every statutory earmarking ("account"), but also among all nonexempt "program[s], project[s], and activit[ies]" within each account. ${ }^{301}$ GRH provides no definition of these key statutory terins. ${ }^{302}$ Instead, it adopts whatever designations are "set forth in the

298. The Impoundment Control Act provided for two forms of impoundment: rescissions (permanent impoundments) and deferrals (temporary impoundments). The former do not take effect unless approved by both Houses of Congress within 45 days-in-session. 2 U.S.C.A. $\S$ 683(b) (West Supp. 1987) (amending 2 U.S.C. $§ 683(b)(1982)$ ). The latter were to take effect unless vetoed by at least one House of Congress. 2 U.S.C. $\S 684$ (1982). However, on the basis of INS v. Chadha, 462 U.S. 919 (1983), the deferral provision has been struck down. See City of New Haven v. United States, 809 F.2d 900, 909 (D.C. Cir. 1987). The President may still temporarily withhold budget authority in some circumstances pursuant to the apportionment provisions of the Anti-Deficiency Act, 31 U.S.C. $\S 1512$ (c)(1) (1982).

299. Cf. Oversight on the Impoundment Control Process, supra note 293, at 183 (statement of Prof. Schick):

[W] hen funds are reprogrammed within the same account, there is no withdrawal of funds, only a change in the use to which they are applied. . . I I believe it far better for Congress to write uniform rules for reprogramming than to [change the law to] subject these administrative actions to the complicated impoundment controls.

300. GRH 1985, supra note 10, $\$$ 252(d), 2 U.S.C. $\S 902$ (d) (Supp. IV 1986) (amended 1987) ("No action taken by the President [in his sequestration order] shall have the effect of eliminating any program, project, or activity of the Federal Government.").

301. GRH 1985, supra note 10, $\$ 252(a)(1)(B)(i), 2$ U.S.C. $\$ 902(a)(1)(B)(i)$ (Supp. IV 1986) (amended 1987); see also id. § 252(e), 2 U.S.C. § 902(e) (Supp. IV 1986) (amended 1987) ("Nothing in the preceding provisions of this section shall be construed to give the President new authority to alter the relative priorities in the Federal budget that are established by law . . ..").

302. Indeed, there is no general statutory definition of what constitutes a "program" in other contexts either. Nonetheless, where one program begins and another ends may be of critical legal relevance. Cf. Grove City College v. Bell, 465 U.S. 555 (1984) (nondiscrimination requirement for college's financial aid eligibility not violated where discrimination occurred in different "program" of 
most recently enacted applicable appropriation Acts and accompanying committee reports." 303

Accordingly, whetler GRH's uniformity requirenent applies to a particular itein of expenditure is decided by future legislatures in appropriations acts or future appropriations committees in their reports. The result is that Congress may limit the amount by which an iten can be sequestered without statutorily allocating an anount for the item if sequestration does not occur. These future specifications of programs, projects, and activities may be as broad or as specific as the prevailing legislature or a congressional committee desires. To make an item of expenditure a "program" for purposes of GRH, it is enough siniply to identify the item as such in eitlier an appropriations act or a comnittee report.

An illustration will demonstrate the importance of Congress' power to define "programs, projects, or activities" in the federal budget. Administrative expenses of the Agricultural Stabilization and Conservation Service are a separate budget "account" under GRH because tliere is an appropriation specifically for this purpose. ${ }^{304}$ Suppose sequestration is necessary and the uniform percentage by which the nonexempt domestic budget must be reduced is five percent. Suppose, furtlier, that the agricultural community in Missouri fears that the Agriculture Department will accoinplisl this five percent reduction by closing some county offices in Missouri while maintaining county offices in neigliboring states. If an appropriations subconımittee witl responsibility for agriculture appropriations can be persuaded to specify that eacli county office is a program, project, or activity, then the funding of every office, including those in Missouri and neigliboring states, can be cut by only five percent.

The designation of prograins, projects, and activities in the event of a sequestration is a quintessentially political task. It allocates public funds, performing a function analogous to statutory earmarking in the traditional appropriations process. Thus, GRH's sequestration rules do not avoid or evade politics; they only cliange, to some extent, the terms of the political debate. Under the traditional system of lump-sum appropriations and informal reprograinming agreements, comnittee reports were understood to be politically but not legally binding. Under GRH, comnittee reports can be expected to assume greater prominence, for they effectively prescribe liow sequestration shall take place.

the college), overruled by statute, Civil Rights Restoration Act of 1987, Pub. L. No. 100-259, 56 U.S.L.W. 45 (1988).

303. GRH 1985, supra note 10, §252(a)(1)(B)(i), 2 U.S.C. $\S 902(a)(1)(B)(i)$ (Supp. IV 1986) (amended 1987).

304. See BUdget of THE UNited STATES GoverNMENT FY 1989, supra note 4, app. at I-E26 (account 12-3300-0-1-351 covers "salaries and expenses" for the Agricultural Stabilization and Conservation Service). 


\section{The Status of Committee Reports Under Gramm-Rudman-Hollings}

The question arises whether GRH violates the Constitution by permitting congressional committee reports to define which items of expenditure constitute programs, projects, and activities. Specifically, does this provision offend the separation-of-powers principle that prohibits according statutory effect to any congressional action short of formal legislation?

Although the constitutional infirmity of binding committee veto provisions has been long recognized, ${ }^{305}$ it was not until the 1983 decision in INS v. Chadha ${ }^{306}$ that the Supreme Court clearly enunciated a rule that invalidates committee vetoes. In Chadha, the House of Representatives, acting alone, had sought to overrule by simple resolution the Attorney General's decision to suspend deportation of Mr. Chadha. The House acted pursuant to a section of the Immigration and Naturalization Act providing that the Attorney General's decision to suspend deportation in certain circumstances would become final only if, by the end of the next session of Congress, neither House vetoed the Attorney General's determination. ${ }^{307}$ The Court held this veto provision-and, by implication, all legislative vetoes ${ }^{308}$ - to be unconstitutional. ${ }^{309}$ A legislative veto purports to have the effect of legislation because it changes the legal positions of those subject to administrative action. ${ }^{310}$ Under the Constitution, however, ouly a measure that is subject to the bicameralism $^{311}$ and presentment requirements ${ }^{312}$ of the Constitution can have legislative effect. Hence, the so-called legislative veto is unconstitutional. Bowsher v. Synar ${ }^{313}$ restated Chadha's understanding of separation of powers even more broadly, denying legal effect to any action in Congress short of legislation: "[A]s Chadha makes clear, once Congress makes its choice in enacting legislation, its participation ends. Congress can thereafter control the execution of its enactment only indirectly_-by passing new legislation." 314

GRH's provision allowing appropriation committees to define programs, projects, and activities may appear to challenge the limited view of congressional power enunciated in Chadha even more directly than

305. See authorities cited supra note 126.

306. 462 U.S. 919 (1983).

307. 8 U.S.C. $\$ 1254(c)(2)(1982)$.

308. See 462 U.S. at $967,1002-13$ (White, J., dissenting) (listing legislative veto laws).

309. Id. at 959 .

310. Id. at 952 .

311. U.S. CoNST. art. I, $\S 1$ ("All legislative Powers herein granted shall be vested in a Congress of the United States, which shall consist of a Senate and House of Representatives.").

312. Id. art. I, $\S 7$ ("Every Bill which shall have passed the House of Representatives and the Senate shall, before it become a Law, be presented to the President of the United States . ...").

313. 106 S. Ct. 3181 (1986).

314. Id. at 3192. 
does the legislative veto. GRH may be read as giving a committee's designations of programs, projects, and activities legislative effect, even though the committee's specifications are neither passed by the House and the Senate nor presented to the President. A committee's designations under GRH would appear to qualify as lawmaking just as surely as the House veto of the Attorney General's decision to suspend deportation of Mr. Chadha. ${ }^{315}$ The task that GRH leaves to appropriation committees, allocation of a reduction im public expenditures, is at the heart of the legislative function. If, as the Court held in Synar, Congress must make law by statute, it is at least arguable that congressional committees should not be able to make such significant political determinations on their own.

The original version of GRH underscored the political significance of defining programs, projects, and activities by specially providing an opportumity to define those terms in the first year of sequestration. Appropriations acts for FY 1986 and accompanying committee reports had already been drafted by the time GRH was enacted, before they acquired their significance for sequestration purposes. GRH therefore provided, for FY 1986 only, that the appropriations committees of both Houses could, after enactment of GRH, issue reports defining programs, projects, and activities. ${ }^{316}$

In fact, in designating programs, projects, and activities for purposes of the FY 1986 sequestration, Congress did not rely simply on the appropriations committees' special reports. ${ }^{317}$ Instead, Congress enacted a joint resolution on December 19, 1985 (one week after GRH was signed) that incorporated detailed designations by appropriations committees of programs, projects, and activities. ${ }^{318}$ This joint resolution incorporated by reference some language in previously issued appropriation committee

315. In Chadha, Chief Justice Burger explained that actions are "essentially legislative" if thcy have "the purpose and effect of altering the legal rights, duties, and relations of persons . . . outside the Legislative Branch," 462 U.S. at 952; presumably "Icgislative effect" would include defining the spending authority of executive officials.

316. Special rules for fiscal year 1986- ... [T] [he Committees on Appropriations of the House of Representatives and the Senate may, after consultation with each other, define the term "program, project, and activity", and report to their respective Houses, with respect to matters within their jurisdiction, and the order issued by the President shall sequester funds in accordance with such definition.

GRH 1985, supra note 10, §252(a)(6)(D)(i)(II), 2 U.S.C. § 902(a)(6)(D)(i)(II) (Supp. IV 1986) (amended 1987).

317. Congress' decision may have been due, in part, to concern about the constitutionality of requiring the President's sequestration order to abide by legislative reports drafted after the passage of GRH.

318. Act of Dec. 19, 1985, Pub. L. No. 99-190, § 101(g), 1985 U.S. CODE Cong. \& ADMIN. News (99 Stat.) 1185, 1291 (incorporating H.R. CONF. REP. No. 450, 99th Cong. 1st Sess. 337-45 (1985)). 
reports $^{319}$ and some budget justifications that had been submitted by executive agencies. ${ }^{320}$ It also included special, new definitions, one of which provided that "[f]or the Agricultural Stabilization and Conservation Service the definition [of program, project, or activity] shall imclude . individual State and county offices." 321 Thus, when the FY 1986 sequestration order went into effect, the Department of Agriculture was required to reduce funding for each county office of the Agricultural Stabilization and Conservation Service by the uniform percentage applicable to the domestic budget.

For all years subsequent to FY 1986, GRH does not provide for supplementary reports or jomt resolutions designating programs, projects, and activities. Rather, GRH expressly rehes on the designations specified in future appropriations acts and accompanying committee reports. The Reagan Administration, ${ }^{322}$ apparently including the President himself, ${ }^{323}$ has questioned the constitutionality of GRH's reliance on future committee reports. The crux of the objection, as stated by the President, is that "material intended to have the force of law must itself be presented to the President." 324

The better view, however, supports the constitutionality of GRH's use of committee materials. GRH's reliance on committee reports to designate programs, projects, and activities is permissible under Chadha and Synar because: (1) GRH itself gives notice that such designations will have the force and effect of law; and (2) the designations have this

319. H.R. Conf. Rep. No. 450, 99th Cong., 1st Sess. 337-44 (1985) (incorporating "the most specific level of budget items" in named statutes and committee reports).

320. See, e.g., id. at 340 (incorporation of Department of Defense "budget justification documents").

321. Id. at 339; see also, e.g., id. ("For the Agricultural Research Service the definition shall include specific research locations ...."). Compare supra text accompanying note 303.

322. See House Comm. on Energy and Commerce Hearings, supra note 254, at 88, 96 (statements of Timothy A. Muris, Executive Associate Director, OMB); see also id. at 78 (statement of James Hinchman, Deputy General Counsel, GAO). The position of OMB is apparently that the reference to "accompanying committee reports" in GRH has no legal effect because a grant of legislative authority to congressional committees would be constitutionally suspect under Chadha. It is possible, however, that OMB's objection applies only if a committee report is prepared after appropriations are passed. The legislative history of GRH as originally enacted reveals no consideration or discussion of any possible constitutional objection to reliance on committee reports.

323. President Reagan in signing GRH in 1985 expressed no concern over the provision relying on committee reports. See 41 Cong. Q. Almanac 36-D (1985). However, in signing the 1987 amendinents to GRH, the President objected to, inter alia, "parenthetical language that could be viewed as atternpting to incorporate committee reports by reference into legislation." 23 WEEKLY COMP. PRES. DOC. 1091 (Oct. 5, 1987). The President referred specifically only to GRH 1985, supra note $10, \S 251(a)(6)(C)(i)$, as amended, which refers to appropriation committec reports concerning pay adjustments. See GRH 1987, supra note 24, § 102(a), 2 U.S.C.A. § 901(a)(6)(C)(i) (West Supp. 1987). The President did not inake exphicit reference to GRH 1985, supra note 10, § 252(a)(1)(B), as amended, which requires more general reliance on committee reports. See 2 U.S.C.A. $\S 902(a)(1)(B)(i)$ (West Supp. 1987).

324. 23 WeEkLY COMP. Pres. Doc. 1091 (Oct. 5, 1987). 
effect only upon enactment of accompanying appropriations legislation. In effect, GRH itself incorporates into future appropriations legislation the program designations im committee reports accompanying that future legislation. Unlike Chadha, where a statute (the Immigration and Naturalization Act) sought directly to give legislative effect to unknown future congressional actions, GRH puts all concerned, including future congresses, on notice that in passing subsequent appropriations acts, Congress is adoptimg the program, project, and activity designations contained in accompanying committee reports. Moreover, GRH's incorporation of committee reports is only partial; that is, the designations of programs, projects, and activities in committee reports are relevant only $\mathrm{m}$ the event of sequestration. If there is no sequestration, then the executive agency may in its discretion depart from these committee report designations.

GRH's use of committee reports "accompanying" appropriations acts is a curious and complicated form of legislation. It is especially worth noting here because it may be a harbinger of a new legislative resolution of the old lump-sum/line-item conflict. ${ }^{325}$ The level of detail at which GRH's uniformity requirement is enforced encoinpasses elements of both statutory earmarkings and committee designations. GRH gives appropriations committees authority to allocate subaccount appropriations for purposes of applying GRH's uniformity requirenent, but both Houses of Congress must adopt the appropriations acts for which the reports are written. At the time these appropriations bills are enacted, the committee report designations and allocations have been published, and their significance for sequestration purposes is known. Moreover, committee report designations by themselves do not reduce the executive's reprogramming authority. Where a committee report (or, for that matter, an appropriations act) contains only a designation of programs, without earmarkings of budget authority announts, the only new limitation on executive discretion presented by GRH is that no program, project, or activity may be eliminated. ${ }^{326}$ Only where a committee report specifies an amount to be allocated to the program does GRH proluibit reprogramming under sequestration. ${ }^{327}$

325. The omnibus appropriation measure for FY 1988 explicitly incorporates committee report earmarking language, see Pub. L. No. 100-220 § 107, 1987 U.S. CODE CoNG. \& ADMIN. NEws (101 Stat.) 1329, 1329-434. See also 1988 CoNG. Q., July 9, 1988, at 1928 (reporting that Sen. McClure, R-Ida., would seek "an amendment to fiscal 1989 spending bills that would make binding that report language agreed upon by both chambers").

326. See supra note 300 and accompanying text.

327. Where a committee report (or an appropriations act) merely designates programs, projects, and activities without allocating a specific amount of funds-as in the example given above for administration of certain agriculture programs-the legal effect of such designation is minimal. Since the administermg agency has discretion over how to allocate appropriations that are not statutorily earmarked, it (and OMB, in the case of executive branch agencies) in effect sets the base 
There is a further constitutional issue lurking in the particular legal effects that GRH gives to committee reports-both where committees earmark specific dollar amounts and where they inerely designate programs, projects, and activities. GRH gives notice that such reports will, upon enactment of the accoinpanying appropriations legislation, have limited legislative effect (in the event of sequestration). But neither House of Congress formally considers or votes upon the substance of these reports. Is it proper, then, to give statutory effect, even in such contingent circumstances as sequestration, to inaterial that is enacted into law only by indirect incorporation? This question is related to a more general concern about relying on committee report language to construe the ineaning of a statute. As then-Judge Scalia noted in a case that involved assertions in a committee report that had not been incorporated, by any means, into legislation: "I think it time for courts to become concerned about the fact that routine deference to the detail of committee reports, and the predictable expansion in that detail which routine deference has produced, are converting a system of judicial construction into a system of committee-staff prescription." 328

The only other form of legislation that presents a situation comparable to GRH's reliance on committee reports is the "continuing budget resolution." These joint resolutions, a form of statute, ${ }^{329}$ are usually enacted at the start of a fiscal year when Congress has failed to enact one or more appropriations acts for the new year. They provide a complex series of directions for determining the funding level at whicli various programs will be temporarily continued, pending enactment of annual appropriations measures. ${ }^{330}$ Often, the terms of a continuing resolution incorporate by reference funding levels that appear only in bills then under consideration in Congress-bills drafted by congressional staff, which have not been considered or voted on by either House of Congress, much less signed by the President. ${ }^{331}$ Unlike the committee veto, the

levels of funding at which the uniformity requirement will be applied. At most, the mere designation of projects, programs, and activities subjects to informal reprogramming procedures any nonuniform sequestration from the budget justification amounts submitted by an agency. That is, if an agency were to atteinpt to sequester more than the uniform percentage for a particular subaccount "program, project, or activity," this reduction might provoke committec review in accordance with reprogramming arrangeinents.

328. Hirschey v. Federal Energy Regulatory Comm'n, 777 F.2d 1, 7-8 (D.C. Cir. 1985) (Scalia, J., concurring).

329. A joint resolution requires passage by a majority of each House and presentation to the President, or passage by two-thirds of each House over the President's veto. See Bowsher v. Synar, 106 S. Ct. 3181, 3204 (1986) (Stevens, J., concurring) (citing 7 L. DeschleR, DeschLER's Precedents of the UNIted States House of RePresentatives 333-34 (1977)).

330. Some continuing budget resolutions actually provide full-year funding and thus substitute for the annual appropriations act.

331. See generally S. Bach, AN INTRoduction to the SPENDing and Budget Process in ConGress (Congressional Research Service Report No. 84-153 GOV, 1984). 
constitutionality of such "incorporated" committee reports cannot be readily determined by reference to particular clauses of the Constitution. Ultimately, both contimumg budget resolutions and GRH's reliance on appropriation committee reports raise unresolved issues concerning the implicit constitutional limitations on the competence of legislation itself.

IV

\section{The ENDURING FisCal Constitution}

Despite its important procedural and substantive limitations on the almual budget deficit and despite its incentive for greater line itemization by Congress, GRH does not fundamentally restructure either the budget or the budget process. As shown in Section A below, sequestration in one year will reduce outlays from sequestered accounts in future years as well. But because most federal spending is entirely exempt from the sequestration process, sequestration under GRH cannot compreliensively restructure the federal budget.

Section B explams why, even if GRH's sequestration provisions were applied to entitlement and other so-called uncontrollable spending, GRH would not fundamentally redesign our fiscal constitution. The most potent mechanism im GRH, automatic sequestration, alters the political burden borne by those who would increase federal spending. But GRH is only a statute, not a constitutional amendment. Accordingly, it does not and caimot reduce legislative power to spend in whatever form and in whatever anounts the incumbent legislature decides. The greater the threatened consequences of sequestration, the less credible the threat becomes; if Congress and the President prefer to evade the consequences of automatic budget cuts, they may readily do so. Our experience under GRH confirms that no statutory spending reduction scheme can be truly automatic.

Section C concludes that GRH's most enduring and significant contribution is not the sequestration process in isolation, but the legislation's overall commitment to a more disciplined legislative budget process. With some glaring exceptions, GRH attempts to tame the traditional budget process in the only way it can be tamed-from within.

\section{A. Gramm-Rudman-Hollings and the Structure of Federal Spending}

The effects of legislative spending decisions inevitably extend beyond one year. For mstance, if Congress enacts budget authority in the current year for a program with a low outlay rate, ${ }^{332}$ thlat budget authority's effect on the deficit will be felt primarily in future years. Likewise, when

332. See supra text accompanying notes $254-55$ for the definition and significance of outlay rates. 
Congress enacts new spending in the form of a continuing statutory entitleinent, future congresses must meet the obligations thus established unless they modify or eliminate the entitlement. Finally, to the extent that the legislative budget process uses the previous year's budget as the baseline measure of spending ${ }^{333}$ from which reductions or additions may be made, clianges in spending in one year can lave a continuing impact in future years. Long-term restructuring of the federal budget, then, must take into account that any one year's spending depends largely on the spending decisions of previous congresses.

The mechanism of sequestration can accomphish some limited restructuring of the federal budget. Because sequestration cuts budget authority rather than simply outlays, it has a direct and substantial impact on future federal spending. Assume arguendo that implementation of GRH's formulae fully achieves the requisite outlay reduction in the sequestration year (though, as suggested above, there may be underestimation of the amount of sequestration required). ${ }^{334}$ This outlay reduction in the sequestration year is only the first-order effect of sequestration. In subsequent years, an additional reduction in outlays will occur. In total, this second-order effect will approximately equal the outlay reduction achieved in the sequestration year, because the average annual outlay rate of nonexempt budget authority is about fifty percent. As the former director of the CBO has explained: "The amount of budget authority sequestered is about twice the amount of needed outlay reductions in a fiscal year because of time lags between the use of budget authority in inaking contracts and other obligations and the issuance of checks to pay for goods and services."335 For example, in the FY 1986 sequestration, GRH called for a reduction in budget authority of over $\$ 24$ billion to achieve the required outlay reduction of $\$ 11.7$ billion. ${ }^{336}$

333. See A. WILDAVSKY, supra note 141, at 135-38. The requirement of the Congressional Budget Act of 1974 that CBO prepare "current services" spending estimates formalized the implicit process described by Wildavsky - with adjustment for inflation. As previously noted, see supra note 260 and accompanying text, the 1987 amendments to GRH further codify the use of a spending baseline roughly equivalent to the previous year's spending levels, adjusted, however, for inflation. See GRH 1987, supra note 24, § 102(a), 2 U.S.C.A. § 901(a)(6) (West Supp. 1987) (amending GRH 1985, supra note 10, § 251(a)(6)).

334. Specifically, I have suggested, see supra notes 281-84 and accompanying text, that GRH does not in fact guarantee elimination of the excess deficit amount, because outlays may be higher than anticipated in the sequestration year due to variance in outlay rates and administrative responses to sequestration itself. To the extent that outlays are higher than anticipated in the sequestration year, they will be lower than anticipated in subsequent years, all other factors remaining equal.

335. House Comm. on Government Operations Hearings, supra note 254, at 72 (written response of Rudolph Penner, Director of CBO, to Rep. Horton) (emphasis added).

336. See Sequestration Report for Fiscal Year 1986, 51 Fed. Reg. 1918, 1937-1938 (1986) (Table 7 showing spending authority sequestration of $\$ 13.8$ billion for defense programs, with resultant outlay reduction of $\$ 5.4$ billion in FY 1986; Table 8 showing spending authority sequestration of $\$ 10.5$ billion for nondefense programs, with resultant outlay reduction of $\$ 6.3$ billion in FY 1986). 
Because sequestration thus necessarily reduces budget authority by more than the current year's deficit, the excess reduction of budget authority causes further outlay reductions in future years. Moreover, the lower the outlay rate of a program, the inore outlay reduction in the program is deferred until future years. ${ }^{337}$

The potential bonus of future outlay reduction was not a publicized, or even an acknowledged, effect of GRH when the legislation was originally debated and adopted. Indeed, it inay not have been generally understood by Congress. As these consequences becoine better understood, Congress might anticipate and counterbalance them by increasing the presequestration budget authority of slow-spending federal programs. Similarly, agencies might engage in postsequestration strategies to obtain supplemental appropriations ${ }^{338}$ by sequestering mostly' slow-spending budget authority. Nonetheless, the "oversequestration" effect of GRH is a novel way of building into the budget a structural imperative of outlay reduction.

In other respects, however, sequestration is not an attractive longterm budget-reduction strategy as threatened or applied. First, to the extent that sequestration cuts spending, it does so in a blunt and econoinically inefficient manner. Rather than examining every spending program and cutting those with the lowest marginal social value, GRH subjects nonexeinpt programs to across-the-board reductions. Yet there is no reason to beheve that the marginal social value of all nonexempt programs is the same, or that the marginal social value of nonexempt programs after sequestration will equal that of exempt programs.

Second, although sequestration threatens to reduce significantly defense expenditures and discretionary nondefense spending, it exempts other critical portions of the budget from any spending reduction. Since the adoption of the unified budget in 1969, and especially since the Congressional Budget Act of 1974, the articulated goal of the budget process has been to reduce "uncontrollable" spendimg on an annual basis, through reconciliation and other restrictions on growth in backdoor

337. The lower the outlay rate, the more the amount by which sequestered budget authority exceeds the outlay reduction in the sequestration year. For instance, suppose a program has new budget authority of $\$ 10$ and estimated outlays of $\$ 8$ from that authority in that year-an outlay rate of 0.8 . Suppose further that the uniform sequestration percentage is, say, $10 \%$. The program's budget authority would be reduced by $\$ 1$ and its outlays would be reduced by $\$ 0.80$ in the sequestration year. A program with the same amount of new budget authority (\$10) but with an outlay rate of only 0.4 would also lose $\$ 1$ in budget authority, but it would suffer only a $\$ 0.40$ outlay reduction in the sequestration year. In short, the lower the outlay rate, the more outlay reduction occurs in future years.

338. This possibility is also noted, from a different perspective, at supra text aceompanying notes 282-86. See infra text accompanying note 377 for a discussion of the status of supplemental appropriations under GRH. 
spending. ${ }^{339}$ Routine sequestration would reverse this trend because GRH exempts most spending from Stage Two. In effect, Stage Two of GRH retreats to a narrow concept of the "controllable" budget, excluding most portions of the budget that are not presently dependent on annual appropriations. Specifically, GRH exeinpts entitlement spending - the part of the budget that has grown most dramatically in the last twenty years. ${ }^{340}$ Some entitlements, such as social security and interest on the national debt, are fully exempted; ${ }^{341}$ others, such as Medicare, ${ }^{342}$ are partially exempt. ${ }^{343} \mathrm{GRH}$ also excludes almost all balances of budget authority from sequestration-both obligated balances, ${ }^{344}$ which often represent contractual obhigations of the United States, and nost unobligated balances, which are usually fungible with new budget authority.

As a consequence of GRH's exemption rules, only fourteen percent of the domestic budget is fully subject to uniform outlay reduction; ${ }^{345}$ this portion of the budget is composed mainly of federal administrative expenses, long-term capital projects not yet funded, and discretionary spendimg such as research grants. Sixty-two percent of defense outlays are potentially subject to sequestration. ${ }^{346}$ However, the President may exempt military personnel payments, which account for half of these outlays; ${ }^{347}$ hence only thirty-one percent of the defense budget is necessarily subject to uniform outlay reduction. Of course, the effect of exempting military personnel is to increase the amount of sequestration froin the more vulnerable defense accounts-composed mainly of civilian administrative costs, discretionary grant programs, and other operating expenses-since half of the aggregate amount sequestered must be taken

339. See supra notes $140-73$ and accompanying text.

340. See SCHICK REPORT, supra note 46, at 18:

Entitlements and other mandatory spending have increased steeply over the past two decades. They climbed from $\$ 35$ billion in fiscal year 1965 to $\$ 167$ billion a decade later and $\$ 440$ billion in the 1985 fiscal year. Entitlements totaled 5.2 percent of GNP in 1965, 10.3 percent in 1975, and 11.2 percent in 1985 . During these decades, entitlements grew from about one-third of total budget outlays to almost one-half of total spending.

See also supra notes 87-93 and accompanying text.

341. See supra notes 232-34.

342. See GRH 1987, supra note 24, § 102(b), 2 U.S.C.A. 906(d) (West Supp. 1987).

343. Entitlement programs that are only partially exempt include student loans, farm price supports, and certain veterans programs. See Initial Sequestration Report FY 1988, supra note 208, at $39,427,39,431-34$.

344. See GRH 1987, supra note $24, \S 102(b)(3), 2$ U.S.C.A. $\S 906(L)$ (West Supp. 1987) (amending GRH 1985, supra note 10, § 256(l)); see also supra notes 235-36 and accompanying text.

345. See Initial Sequestration Report FY 1988, supra note 208, at 39,426-27. However, an additional $12 \%$ of the nondefense budget is subject to partial sequestration or reduction in cost-ofliving increases. See id.

346. See id. (38\% of defense budget exempt, due primarily to exemption of obligated balances).

347. GRH 1987, supra note 24, §102(a), 2 U.S.C.A. $\S 901$ (d)(3)(A) (West Supp. 1987); see also id. 2 U.S.C.A. $\$ 902(\mathrm{c})(2)(\mathrm{A})$ (West Supp. 1987). The President exercised this authority with respect to the FY 1988 sequestration. See Emergency Deficit Control Measures for Fiscal Year 1988, supra note 221. 
from the defense budget. ${ }^{348}$

In effect, then, GRH exempts in whole or in part most of the "uncontrollable" portion of the federal budget. As noted previously, this portion of the budget actually is controllable by Congress, in the sense that Congress has constitutional authority to reduce entitlement and other expenditures by altering substantive legislation. Indeed, in many instances, Congress can even reduce outlays for obligated balances, since federal contracts often specifically condition payment on "the availability of appropriations" and provide for termination payments. ${ }^{349}$

Congress and the President might have seized upon GRH's sequestration procedure as an opportunity to assert control over the so-called uncontrollable budget. There is no reason in principle why all federal payments, including those under entitlement programs and even sonie payments due under contracts, could not be made subject to automatic, across-the-board spending reduction. Indeed, in ternns of ease of implementation, entitlement payments are more amenable to across-the-board sequestration than are most discretionary federal outlays. As explained in Part III above, OMB must calculate annual outlay rates for various types of budget authority in order to reduce nuost federal spending programs by a uniforin percentage. For entitlenent prograins, OMB can simply cut each nidividual payinent by the apphicable unifornn percentage. The technical ease with which entitleinent programs can be cut nirrors the technical ease with which they can be increased (as they routinely are) through built-in cost-of-living allowances.

In fact, GRH does accomphish soine niarginal restructuring in the uncontrollable budget because it only partially exenupts several important entitlement programs $s^{350}$ and eliminates autornatic spending increases in a few sniall programs. ${ }^{351}$ Still, GRH provides for fnll funding of nost entitlements. Had the legislation provided for autoniatic reduction of entitlement paynients, instead of the usual autoinatic increases, its strategy would truly have been a radical departure froin past practice. Once enacted in GRH, autoniatic entitlenient reductions night have been politically difficult to reverse, just as in the traditional legislative process it is pohtically difficult to repeal automatic increases nis entitleinents.

348. See GRH 1987, supra note 24, $\S 102(a), 2$ U.S.C.A. $\$$ 901(a)(3)(b) (West Supp. 1987).

349. See, e.g., Blackhawk Heating \& Plumbing Co. v. Umited States, 622 F.2d 539 (Ct. Cl. 1980). See generally Fenster \& Volz, The Antideficiency Act: Constitutional Control Gone Astray, 11 Pub. ConT. L.J. 155 (1979) (discussing effect of Anti-Deficiency Act on federal contract law). As originally enacted in 1985, GRH allowed the President discretion to seek termination or modification of defense contracts (deobligation of obligated balances) where cost-efficient. GRH 1985, supra note 10, § 251(d)(3), 2 U.S.C. $\S 901$ (d)(3) (Supp. IV 1986) (amended 1987). The President did not use this authority in the FY 1986 sequestration.

350. See supra notes 342 and 343 and accompanying text.

351. See GRH 1987, supra note 24, $\S 102$ (b), 2 U.S.C.A. $\S 907$ (1) (West Supp. 1987) (vocationa1 reliabilitation program, special milk program, and National Wool Act program). 
GRH's exemption of nearly all entitlement payments underscores the pohtical vitality and strength of these programs-the strength that made these programs practically invulnerable im the traditional legislative budget process. Most major middle-class entitlements, such as social security, are automatically funded each year; Congress must affirmatively act to cut these programs. Indeed, Congress must act even to prevent automatic pay increases because cost-of-living adjustments are often built into the underlying substantive legislation. Although it is not surprising that entitlement programs, even those nominally subject to annual appropriations, are exempted froin sequestration under GRH, their exemption reveals the ultimate weakness of sequestration as a strategy for redesigning the federal budget.

Even though exempted from sequestration, entitlement and other exempted programs could still be reduced in Stage One--the legislative budget process--through reconciliation legislation. The very threat of sequestration, however, inay make it less likely that Congress will significantly reduce any of these programs in the Stage One process. Programs that are exempt from sequestration are in a stronger bargaining position than are programs that face automatic reduction in the absence of a Stage One budget agreement. Supporters of such programs have less reason to accept a marginally unfavorable legislative budget than do supporters of programs that are vulnerable to sequestration.

At the same time, the threat of sequestration may create a perverse incentive with respect to nonexempt programs. The budget baseline provisions in the original version of GRH clearly discouraged supporters of a program from enacting timely appropriations that would reduce spending for the program. If a full-year appropriations bill were enacted before the beginning of the next fiscal year, the new (lower) spending level would be used to calculate both the excess deficit and the budget basehine from which sequestration would be made. ${ }^{352}$ If the aggregate budget that emerges from the Stage One process did not achieve GRH's deficit requirement, programs for which a lower level of funding had been enacted would be subject to a second round of reductions by sequestration. ${ }^{353}$ Likewise, if permanent funding legislation were amended to reduce some form of backdoor spending authority, the sequestration

352. GRH 1987, supra note 24, § 102(a), 2 U.S.C.A. $\S 901$ (a)(6)(C)(i) (West Supp. 1987) (amending GRH 1985, supra note 10, §251(a)(6)(B)).

353. See House Comm. on Government Operations Hearings, supra note 254, at 19 (colloquy between Rep. J. Brooks and Charles Bowsher, Comptroller General):

Mr. Brooks. What incentives ... are there to complete action on the appropriations bills, if it means that the Federal agencies would take double cuts as a result of the GrammRudman-Hollings sequestration?

MR. BowSHER. [T]here's a great reluctance in passing appropriations because of the very issue you raise .... 
baseline would be the new, lower spending level..$^{354}$ As amended in 1987, GRH reduces but does not eliminate the disincentive to cut spending in the legislative budget, by providing that reductions in baseline spending enacted after OMB's sequestration report will be offset by reductions in the ainount sequestered. ${ }^{355}$

In sum, strategic considerations suggest that the threat of sequestration may make agreement on a Stage One budget inore difficult to reach, at least in a timely fashion, and may even make sequestration more likely to occur. ${ }^{356}$ Sequestration can only cut the budget as it finds it; uniform spending cuts cannot, by themselves, change federal priorities or commitments. GRH as now formulated alters the structure of federal spending priorities primarily by insulating most uncontrollable spending from the threat of across-the-board reduction. In this respect, GRH is no more successful than the traditional budget process in enabling Congress to achieve meaningful control over federal spending. Neither the Anti-Deficiency Act nor appropriations in terms of budget authority have prevented obligation in excess of and outside of appropriations legislation. ${ }^{357}$ The only way to impose budgetary control over uncontrollable spending

354. See GRH 1987, supra note 24, § 102(a), 2 U.S.C.A. $\S 901(a)(6)(A)$ (West Supp. 1987) (amending GRH 1985, supra note 10, §251(a)(6)(A)).

355. See id. $\S 102(b), 2$ U.S.C.A. $\S 902(f)(2)(B)$ (West Supp. 1987). This section provides that if the full-year appropriation effects a savings from the baseine spending assumed in OMB's sequestration calcnlations, then the amount sequestered will be reduced by the amount of the savings. Thus, there is no double reduction if the full-year appropriations act is enacted after the amount of sequestration is calculated. However, this new provision in the 1987 amendments to $G R H$ also specifies that in no event may an amount greater than that specified in the sequestration order be sequestered. Id. Hence increases in baseline spending in the full-year appropriation are not offset by increases in the amount sequestered; the effect of this provision is discussed infra text accompanying note 376 .

356. Congress' behavior since GRH's enactment certainly suggests as much. In every year, appropriations bills were enacted in consolidated, omnibus measures after the fiscal year had begun. For FY 1986, the Consolidated Omnibus Budget Reconciliation Act of 1985, Pub. L. No. 99-272, 1986 U.S. Code CONG. \& ADmin. News (100 Stat.) 82, was not sent to the President until late March 1986, nearly one month after sequestration for FY 1986 had begun.

For FY 1987, no budget was enacted until after the preliminary $\mathrm{CBO} / \mathrm{OMB}$ sequestration report indicated that seqnestration (under GRH's original "backup" joint resolution) would not be necessary. See Revised Sequestration Report for Fiscal Year 1987, 51 Fed. Reg. 35,622, 35,623 (1986). This report conciuded that GRH's deficit requirement would be met if Congress enacted the reconciliation act and other items of fiscal legislation then under consideration. Id. Congress passed the Omnibus Budget Reconciliation Act of 1986 shortly afterwards. Pub. L. No. 99-509, 1986 U.S. CODE CONG. \& ADMIN. News (100 Stat.) 1874 (passed on October 17, 1986, and signed by the President on October 21, 1986).

For FY 1988, Congress had not enacted any appropriations or reconciliation legislation when sequestration went into effect on November 20,1987. Subsequently, Congress enacted omnibus appropriations, reconciliation, and tax legislation and simultaneously cancelled the November 20 sequestration, see supra note 221. See Pub. L. No. 100-202, 1987 U.S. CodE Cong. \& AdmiN. NEws (101 Stat.) 1329.

357. See supra text accompanying notes 64-68. 
is to remove its imsulation and renegotiate its terms. ${ }^{358}$

Recent structural changes on the revenue side of the budget increase the importance of directly addressing the structural rigidities of federal spending. Changes in tax pohicy portend less automatic revenue growth than in the past. As a result of tax indexing, autoinatic annual revenue increases due to inflation-the "inflation dividend"-are lost. ${ }^{359}$ Similarly, the movement toward a flat tax rate over inost of the incoine schedule removes the revenue bonus from "bracket creep."360 Finally, one ineans of increasing tax revenues-closing "loopholes"- has been partially foreclosed, since inany tax expenditures have been eliminated. ${ }^{361}$ In sum, even if there is pohtical determination to freeze the aggregate level of federal spending, revenues might be frozen at an even lower level.

\section{B. Legislative Power Under Gramm-Rudman-Hollings}

In subjecting soine budgets to automatic spending cuts, GRH actually alters the legal consequences of spending legislation. Without GRH, the amount of budget authority would be determined solely on the basis of appropriations acts and other legislation that grants budget authority. Under GRH, however, the ainount of budget authority depends upon both spending legislation and whether sequestration is triggered. In order to avoid GRH's deficit limits and its sequestration juggernaut, Congress must both enact a budget violating GRH's limits and enact legislation repealing, modifying, or suspending GRH.

Paul Kalin argues that this strategy of automatic spending cuts is constitutionally suspect. ${ }^{362}$ In Kahn's view, Congress may not be empowered to require a future Congress to act twice, in effect, in order to undo one previous legislative enactment (in this case, GRH). ${ }^{363} \mathrm{GRH}$,

358. See also Schick RePORT, supra note 46, at 18-19 ("If Congress wants . . . to impose budgetary control on entitlement spending, Congress must devise means other than annual appropriations.").

359. Economic Recovery Tax Act of 1981, § 104, I.R.C. $\S 1(f)$ (1982 \& Supp. III 1985). Rate schedules, personal exemptions and zero bracket amounts have been adjusted annually since 1985 to reflect changes in the Consumer Price Index.

360. "Bracket creep" occurs when marginal tax rates increase as income (real as well as inflated) increases. The Tax Reform Act of 1986, Pub. L. No. 99- 514, 100 Stat. 2085, reduces the number of permanent tax rate brackets to two. See I.R.C. $\$ 1$ (Supp. IV 1986).

361. See Rauch, The Fiscal Ice Age, 19 NAT'L J. 58, 63 ("the exemptions and deductions that survived the tax reform process are the most popular").

362. See Kahn, Gramm-Rudman and the Capacity of Congress to Control the Future, 13 HASTINGS CONST. L.Q. 185 (1986). Kahn does not explicitly claim that GRH is unconstitutional.

363. Kahn argues that GRH requires repeal and subsequent appropriation in order to increase federal spending, rather than only an appropriations act that by its terms would have this effect. Id. at 204-06. In Kahn's view, this changes the character of legislative decisionmaking and the effect of legislative inertia and thus "distorts the legislative product of future Congresses," id. at 206, renders too much legislative behavior "strategic," id. at 208-09, "displaces legislative accountability," id. at 209 , and undermines the "constitutional quality of legislating as an activity of governance," id. at 207. 
he argues, "create[s] a substantial burden on the ability of a future legislature to carry out its own legislative agenda." 364 Under this view of legislative power, ${ }^{365}$ however, all permanent legislation would be suspect. After all, every generally applicable legislative prescription that is not limited in time necessarily "distorts the legislative product of future Congresses." 366 The later legislation must inodify or revoke the operation of the earher prescription in order to avoid its constraints. For instance, the requirements of the Endangered Species $\mathrm{Act}^{367}$ apply to all subsequent as well as previous appropriations. The Act effectively prevents federal spending that would have been authorized, or even mandated, in its absence. ${ }^{368}$ The Freedom of Information Act and the Environmental Protection Act have had a similar inpact upon all subsequent appropriations not exphicitly exempted from thein. Although appropriations legislation is enacted every year, the legal effect of this legislation is necessarily determined in part by previous legislation.

Moreover, apart from appropriations, permanent legislation is the norm. Congress need not and does not annually reenact the criminal law codified in Title 18 of the United States Code. It is enough that Congress has power to do so: the power to reenact, repeal, or otherwise modify Title 18. Unless legislation purports to take away a future Congress' power to repeal or alter the legislation, the earlier legislation does not overstep each Congress' power to provide for the future.

In the legislative budget process itself, Congress usually enacts permanent legislation for revenue programs and for statutory entitlements and other backdoor spending. GRH adapts this strategy and redirects it to a different end. GRH's prescriptions apply automatically unless repealed or until GRH expires. ${ }^{369}$ Entitlement funding is automatic in the same way: it continues unless affirmative action is taken to amend or

364. Id. at 229. In Kahn's view, GRH's burdens on future congresses are particularly dubious because GRH achieves them by asserting "control over the rule-making of future Congresses," $i d$. at 211.

365. See also Eule, Temporal Limits on the Legislative Mandate: Entrenchment and Retroactivity, 1987 AM. B. Found. REs. J. 379. Professor Eule, expressing agreement with Kahn's qualms about the constitutionality of GRH, argues that GRH burdens future congresses that may disagree with it. According to Eule, this is "precisely the sort of extratemporal influence that our temporary agents should not enjoy." Id. at 426 n.215.

366. Kahn, supra note 362, at 206; cf. Eule, supra note 365, at 404-05 (arguing that Congress may not extend its influence beyond its term of office set by the Constitution).

367. 16 U.S.C. $\$ \S 1531-1543$ (1982); see id. $\S 1536(a)(2)$ (requiring that actions "authorized, funded, or carried out by [federal agencies do not] jeopardize the continued existence of any endangered species") (emphasis added).

368. See TVA v. Hill, 437 U.S. 153, 189-93 (1978) (when Congress enacts general legislation, such as the Endangered Species Act, subsequent appropriations are subject to such lcgislation in the absence of an exemption).

369. The sequestration provisions of GRH as amended expire in 1993. See GRH 1987, supra note 24, $\S 106($ c), 2 U.S.C.A. $\$ 901$ note (West Supp. 1987). 
repeal it. While the conventional budget process employs this strategy to permit continued spending, GRH employs it to prevent continued spending at the same or higher levels. Congress' special obhgations under the Constitution's appropriations clause might be violated by enactinent of permanent, automatic spending cuts not contingent on future appropriations legislation. ${ }^{370} \mathrm{GRH}$, however, provides only for contingent spending reductions, known in advance by future Congresses, and the threat of sequestration does not obviate the need for each Congress to exercise its appropriations power.

Nor is there anything structurally untoward or startling about GRH's making future spendimg depend on a particular contingency. In fact, the traditional appropriations process frequently einploys contingent appropriations: $X$ amount is available if one set of conditions occurs; $Y$ ainount (or even zero), if another set occurs. ${ }^{371}$ Similarly, both the Anti-Deficiency Act of $1905^{372}$ and the Impoundment Control Act as originally enacted in $1974^{373}$ make the timing of all appropriations contingent. GRH adopts the same contingency mechamism and applies it to the whole expenditure budget. ${ }^{374}$ Under GRH, certain appropriations in the legislative budget process are contingent on whether sequestration is triggered, and, if so, on the application of GRH's sequestration formulae. Both in conventional contingent spending legislation and under GRH, occurrence of a precondition withdraws, to a statutorily specified extent, the legislative permission or mandate to spend. GRH's precondition is the failure of the legislative budget process to yield a lower deficit.

The contingent threat of sequestration is part of the frainework in

370. Elsewhere I propose that under the appropriations clause Congress is obliged to limit the duration and amount of each appropriation. See Stith, supra note 37, at Section III. If permanent, noncontingent spending cuts would be inconsistent with this obhigation, then surely the conventional practice of permanent appropriations for entitlements is even more constitutionally suspect. Neither Kahn nor Eule question the constitutionality of permanent appropriations, and neither relates their concerns to any special duty of Congress under the appropriations clause.

371. See Rosenthal, Conditional Federal Spending and the Constitution, 39 STAN. L. REv. 1103 (1987); Note, The Spending Power of Congress-Apropos the Maternity Act, 36 HARV. L. REV. 548 (1923).

372. Executive apportionment authority under the Anti-Deficiency Act is discussed supra text accompanying notes 111-14. The Anti-Deficiency Act directs federal agencies to create contingency reserves when exercising apportionment authority. See City of New Haven v. United States, 809 F.2d 900, 901, 909 (D.C. Cir. 1987); PrinCiples, supra note 60, at 5-42 to 5-44.

373. As originally enacted the Impoundment Control Act permitted administrative deferral of spending unless such deferral was disapproved by at least one House of Congress; however, the deferral provision was struck down in City of New Haven, 809 F.2d at 909; see supra note 298. The 1987 amendments to GRH alter the Impoundment Control Act to provide that deferral of spending may be undertaken only pursuant to the Anti-Deficiency Act. GRH 1987, supra note 24, § 206(a), 2 U.S.C.A. $\S 684$ (West Supp. 1987). All other impoundments must be approved by Congress.

374. Synar v. United States, 626 F. Supp. 1374, 1387 (D.D.C. 1986) (3-judge court) (per curiam) (GRH "is no more than a form of contingent legislation"), aff"d sub nom. Bowsher v. Synar, 106 S. Ct. 3181 (1986). 
which post-GRH congresses enact budget legislation. After GRH, future budget legislation will be subject not only to the Endangered Species Act, the Freedom of Information Act, the Environmental Protection Act, the Anti-Deficiency Act, the Impoundment Control Act (and so on), but also to the budget-balancing rules of GRH itself. The mere enactment of a budget that exceeds GRH's targets does not, as Professor Kahn seems to argue, ${ }^{375}$ show a legislative purpose to exceed GRH's deficit maximumany more than providing funds for federal construction projects shows a purpose to affect the environment in contravention of federal environmental laws. Future congresses that enact deficit-increasing budgets know how these budgets will fare under GRH, and it seeins counterintuitive to assume that Congress intends the opposite of what it knows. If, on the other hand, Congress exempts a deficit-increasing budget from GRH or suspends or repeals GRH, that action clearly would indicate a legislative intent to increase deficits despite GRH. Congress need not act twice to undo GRH; it need only act once, but that act must indeed show an intent to inodify, suspend, or undo GRH.

In fact, due to "loopholes" in GRH itself, Congress may abandon GRH's deficit targets and himitations even without repeal or ainendinent. As amended in 1987, GRH allows Congress to increase baseline spending for a program (but not the ainount sequestered) by waiting to enact the regular, full-year appropriation until after the final sequestration amount has been calculated. Because of this "baseline spending" loophole, the gross ainount sequestered may not be enough to achieve GRH's deficit inaximum. ${ }^{376}$

GRH contains a second loophole, a "suppleinental spending" loophole, which has a similar effect. Because none of GRH's deficit limitations apply to supplemental appropriations, Congress may exceed the deficit maximum despite sequestration. Under GRH, the impact of fiscal legislation is judged on only two occasions, the two snapshot dates. ${ }^{377}$ If OMB concludes that the deficit target will not be inet, the President must issue either a prelminary or final sequestration order. However, any suppleinental appropriations enacted after the final snapshot date do not affect whether sequestration will occur or, in the event of sequestration, how much will be sequestered. If OMB issues a final report concluding that the deficit target in GRH will be achieved, sequestration is avoided in that fiscal year. This is true even if, on the next day, the President

375. See Kahn, supra note 362 , at 210 (enactment of deficit-increasing budget likely involves a "majority to spend more than the deficit targets and simultaneously a majority not to repeal Gramm-Rudman").

376. Any increase in baseline spending enacted after the final sequestration amount is calculated will not increase the amount sequestered. GRH 1987, supra note 24, 2 U.S.C.A. $\S 902(f)(2)$ (B) (West Supp. 1987); see supra note 354 and accompanying text.

377. See supra notes $210-15$ and accompanying text. 
signs new spending legislation that authorizes spending in excess of the deficit target. Alternatively, if OMB concludes that sequestration is necessary, and the President issues a final sequestration order, Congress inay subsequently enact legislation reappropriating the amount sequestered or providing even inore suppleinental spending authority.

The "baseline" and "suppleinental" spending loopholes are of a different order than the programmatic and other exemptions in GRH. ${ }^{378}$ Whereas spending on exeinpted programs inerely increases the amount of sequestration required in nonexeinpted programs, postsequestration increases in baseline spending and suppleinental appropriations are excluded not only froin sequestration but also froin GRH's inaximum deficit prescriptions. These loopholes could undercut and, conceivably, even coinpletely undo the deficit-reduction that GRH would otherwise achieve.

The spending loopholes are not unavoidable or inevitable flaws of an autonatic spending reduction scheme. GRH could have avoided them by providing for additional sequestration reports and orders during the fiscal year. Alternatively, the law could have provided that such spending increases enacted during one year would be recaptured in the next year's sequestration. Congress has not been willing, however, to accept the burden on legislative spending power imphied by subjecting the whole budget to a statutory deficit limitation. The baseline spending and supplemental spending loopholes serve as important pressure release valves, allowing Congress the option of increasing spending on a selective basis without having to repeal or amend GRH.

The evidence shows that GRH has not unduly burdened Congress' legislative powers. Congress has exercised its power to spend despite GRH (taking advantage of its loopholes), as well as its power to repeal, suspend, and amend GRH. The first sequestration under GRH had barely begun when Congress amended the legislation to exempt additional prograins and categories of spending froin sequestration and to restore soine sequestered budget authority. ${ }^{379}$ During the next two years, Congress enacted additional legislation exempting still more programs from sequestration. ${ }^{380}$ Finally, in enacting the 1987 amendments to GRH, Congress not only corrected the constitutional defect identified in Synar, but also enacted the baseline spending loophole and significantly loosened GRH's deficit-reduction requirements, extending by two years the deadline for reducing the deficit to zero. For FY 1988, Congress

378. See supra notes $232-36 \& 340-48$ and accompanying text.

379. See Consolidated Omnibus Budget Reconciliation Act of 1985, Pub. L. No. 99-272, 1986 U.S. CODE CONG. \& ADMin. News (100 Stat.) 82.

380. These additional exemptions are listed and "specifically include[d]" in the 1987 amendments to GRH. GRH 1987, supra note 24, § 104(b), 2 U.S.C.A. § 905 (West Supp. 1987). 
changed the maximum deficit amount from $\$ 108$ billion, which would have required spending cuts or tax increases totalling over $\$ 45$ billion, ${ }^{381}$ to a reduction of $\$ 23$ billion. ${ }^{382}$ Congress also provided that henceforth the spending baseline estimate would include an inflation adjustment, which for FY 1988 amounted to more than $\$ 11$ billion. ${ }^{383}$ Accordingly, the actual deficit reduction for FY 1988 from the previous year's baseline became less than $\$ 12$ billion. ${ }^{384}$

\section{Conclusion: The Political Budget Process}

Poitical choices have produced spending growth unaccompanied by commensurate revenue growth. The federal budget is difficult to reduce largely because it harbors these entrenched political choices and obligations made by previous generations. Indeed, the fastest growing component of federal expenditures in recent years has been the most overt legacy of past political choices-payment of interest on the national debt. "Entitlement" payments liave grown nearly as fast.

GRH constrains Congress in the exercise of its constitutional power to spend. Ultimately, however, this constraint is political, not legal. Because the meclramism of sequestration is not of constitutional stature, ${ }^{385}$ its power, whether it is implemented or avoided, is constrained by the political budget process. If implemented, sequestration operates upon the outcomes of the traditional legislative budget. As shown above, appropriations legislation can never specify every detail of spending. It thus requires the exercise of administrative discretion and is not, after enactinent, easily reduced across-the-board. Moreover, automatic spending reductions do not provide for political resolution of the tensions that inhere in the legislative budget process. A system of formulaic spending cuts requires a meclianical approach to deficit reduction irrespective of the preferences of the polity, and it demands that the "deficit excess" be eliminated solely by reducing expenditures. The sequestration rules and formulae in GRH reflect major political compromises to satisfy impor-

381. See Sequestration Report for Fiscal Year 1988, 52 Fed. Reg. 31,530, 31,537 (1987) (average of CBO and OMB deficit estimates for FY 1988 was $\$ 153.4$ billion).

382. The 1987 amendments to GRH provide that for FY 1989 the maximum deficit reduction is $\$ 36$ billion, see supra note 201 and accompanying text.

383. See Initial Sequestration Report FY 1988, supra note 208, at 30,421 (Table 2).

384. Because the 1987 amendments to GRH state the deficit prescription for FY 1988 and FY 1989 in terms of deficit reduction (from an inflation-adjusted baseline) rather than in terms of a definite deficit maximum, GRH does not require that any deficit target be met until FY 1990. See supra notes 201-02 and accompanying text.

385. A binding deficit ceiling could be achieved by the much-discussed balanced budget amendment to the Constitution. For some supporters of GRH this was, and is, the ultimate political objective. See supra note 190. Even if a constitutional deficit limitation were politically attainable, however, an extralegislative mechanism such as sequestration would have to be adopted to enforce the constitutional limitation. 
tant constituencies. Over time, however, these particular compromises may become less and less satisfactory, due to both changes in prevailing political preferences and the consequences of deficit reduction.

GRH's deficit ceiling, enforced by sequestration, is like the lid of a pressure cooker. Whether it holds depends on the amount of pressure in the pot and the countervailing pressure that keeps the lid in place. I have suggested that the pressures of the budgetary process are great and will grow due to the operation of GRH itself. As the deficit limitations stated in GRH become progressively more difficult to achieve, Congress may simply legislate higher deficit maximums or enact more supplemental appropriations. In other words, Congress may simply release the pressure of the automatic sequestration process which is intended to hold the lid on spendimg.

Accordingly, GRH cannot be expected to achieve significant restructuring of the budget or significant deficit reduction unless the Stage One budget process-the traditional legislative process--is capable of yielding a budget within GRH's deficit mandates. GRH's deficit inaximums become progressively lower each year. Unless Congress adheres to these limitations, the size of mandated spending cuts will increase each year. At some poimt, Congress and the President may find it politically inpossible to permit the reductions in the discretionary budget that sequestration implies; the politically easier route may be legislative modification of GRH's deficit ceiling-precisely what happened when Congress amended GRH in $1987 .{ }^{386}$ Achieving, or even approaching, a balanced budget under GRH requires that the legislative budget process yield tax mcreases and decreases in backdoor spending, as well as cuts in the discretionary budget.

Because the budget "crisis" will have to be resolved in the legislative process, GRH will not make an enduring contribution unless, beyond threatening sequestration, it fortifies the budget procedures that Congress estabhished for itself in the Congressional Budget Act of 1974. With that earlier enactment, Congress sought to take control of the budget from the President. But legislative primacy alone will not lead to deficit reduction.

To an extent, GRH does strengthen the ability of Congress to enact a comprehensive, coordinated, and deficit-reducing budget each year. ${ }^{387}$ Stage One of GRH established internal procedures which, if followed,

386. See supra notes 201-02 and accompanying text. Congress may do for FY 1990 what it has done for FY 1988 and FY 1989; namely, amend GRH to replace the prescribed deficit maximum with a deficit-reduction amount that Congress determines it will, in fact, meet. See supra note 384.

387. See also Wehr, Court Strikes Down Core of Gramm-Rudman, 44 CONG. Q. WeEKLY REP. 1559, 1562-63 (1986) (discussing remaining significance of GRH); Bowsher v. Synar, 106 S. Ct. 3181 (1986). 
will result in a budget that reduces the deficit. Specifically, GRH strengthens House and Senate rules requiring compliance witl congressional budget resolutions. Since the enactment of the Congressional Budget Act of 1974, the legislative budget process has revolved around the congressional budget resolution. This concurrent resolution, unlike a joint resolution, has no binding legislative significance and before GRH, had little internal legal significance. Pohtical considerations made it advantageous to pass a resolution pronising minimal spending growth, but eitlier House could, and routinely did, violate a resolution's spending limitations. ${ }^{388}$ Under GRH, however, once Congress passes a budget resolution that meets the deficit maximuin, point-of-order objections make it difficult to depart froin that resolution; ${ }^{389}$ in the Senate, objections can be waived only by a supermajority of sixty percent. ${ }^{390}$ GRH also strengthens other procedural limitations in the budget process. ${ }^{391}$ Finally, both the House and the Senate have standing rules that would make it difficult for a simple majority to repeal the internal requirements imposed by GRH. ${ }^{392}$

388. See supra notes 161-163 and accompanying text.

389. GRH 1985, supra note 10, § 201(b), 2 U.S.C. $\S 632(i)$ (1)(A) (Supp. IV 1986) (amending Congressional Budget and Impoundment Control Act of 1974, $\$ 301(\mathrm{i})(1)(\mathrm{A})) ;$ id. 2 U.S.C. $\S 633$ (c) (Supp. IV 1986) (amending § 302 of 1974 Act); id. 2 U.S.C. § 641(d) (Supp. IV 1986) (amending $\S 310$ of 1974 Act); id. 2 U.S.C. $\S 642$ (Supp. IV 1986) (amending $\S 311$ of 1974 Act).

390. Id. 2 U.S.C. $\$ 632(\mathrm{i})(1)(B)$ (Supp. IV 1986) (amending Congressional Budget and Impoundment Control Act of $1974, \S 301(\mathrm{i})(1)(B))$. It would appear that a $60 \%$ supermajority is required to alter GRH's supermajority requirement. A similar supermajority requirement is required by Senate Rule XXII(2), dealing with motions to invoke cloture of debate in the Senate. This rule requires a three-fifths affirmative vote of the Senators "duly chosen and sworn" in support of a motion to cut off debate. Senate Commirtee on Rules \& Administration, Standing Rules of THE SeNate, S. Doc. No. 22, 99th Cong., 2d Sess. 15-16 (1986) [hereinafter Standing RULES OF THE SENATE]. Efforts to circumvent the strictures of Rule XXII(2) by appeal to art. I, $\S 5$ of the Constitution (allowing "each House" to promulgate its rules) have failed. In 1959 in order to insulate Rule XXII(2) from repeal by a simple majority, the predecessor of Senate Rule V(2), see infra note 392, was enacted. See also Eule, supra note 365, at 407-12 (arguing that the predecessor of Rule V(2) is constitutionally suspect because it "entrenches" Senate rules).

391. Section 301(c) of the Congressional Budget and Impoundment Control Act of 1974, as amended by GRH, prohibits the annual budget resolution from requiring "any procedure or matter which has the effect of changing any rule of the House of Representatives" without a concurrent report from the Rules Committee. GRH 1985, supra note 10, § 201(b), 2 U.S.C. § 632(c) (Supp. IV 1986).

In the Senate, GRH imposes even greater procedural limitations. It amends $\S 904$ of the 1974 Act ("Exercise of Rulemaking Powers") to require "three-fifths of the Members, duly chosen and sworn" to amend budget legislation. GRH 1985, supra note 10, § 271(a), 2 U.S.C. $\S 621$ note (Supp. IV 1986). Similarly, GRH requires a three-fifths majority for the waiver or suspension of other budget process rules ( $\S 301(\mathrm{I}), 302(\mathrm{f}), 304(\mathrm{~b}), 310(\mathrm{~d}), 310(\mathrm{~g}) \& 311(\mathrm{a})$ of the 1974 Act). GRH 1985, supra note 10, $\$ 271$ (b), 2 U.S.C. $\$ 901$ note (Supp. IV 1986). These three-fifth requirements in the Senate apply only through the expiration of GRH's sequestration provisions, on September 30, 1992. See GRH 1987, supra note 24, § 205(a), 1987 U.S. CODE CoNO. \& ADMIN. NEWS at 784 (section not codified).

392. If the measure or motion before the Senate amends that body's rnles, two-thirds of the Senators "present and voting" must support it. STANDiNg RULES OF THE SENATE, supra note 390, 
Unfortunately, GRH's fortification of the traditional legislative budget process is far from complete. Postsequestration spending is enacted both outside of GRH's procedural requirements and, as previously explained, beyond the threat of sequestration. Moreover, GRH's sequestration formulae create coinpeting incentives. While Congress as an institution has an incentive to avoid sequestration by cutting the aggregate deficit, there remain strong incentives for individual legislators not to agree to reductions in specific prograins.

Even if GRH had more comprehensively and consistently reformed the Stage One process, of course, such reform could no more ensure deficit reduction than could sequestration by itself. As GRH clearly indicates, ${ }^{393}$ in establishing its procedures for consideration of budget legislation, Congress acted pursuant to the constitutional power of each House to control its internal operations. ${ }^{394}$ Thus, although these new procedures have been enacted by statute, passed by each House and signed by the President, either House may, pursuant to its own rules, modify thein in the future. ${ }^{395}$ Because GRH's budget process requirements are ouly internal rule changes, they cannot constitutionally bind future congresses. ${ }^{396}$ They are binding only so long as each House chooses to uphold them as a matter of institutional integrity and political will. ${ }^{397}$

at 15-16. Rule V(1) of the Standing Rules of the Senate states: "Any rule may be suspended without notice by the unanimous consent of the Senate, except as otherwise provided by the rules." Id. at 4. Rule V(2) interposes a check against any new session of the Senate attempting to replace old rules with new rules: "The rules of the Senate shall continue from one Congress to the next Congress unless they are changed as provided in these rules." Id.

The Rules of the House of Representatives, H.R. Doc. No. 279, 99th Cong., $2 d$ Sess. 644 (2d ed. 1987), provide in Rule XXVII(l) that: "No rule shall be suspended except by a vote of two-thirds of the Members voting, a quorum being present . ..." However, the House, unlike the Senate, permits each newly elected body of Representatives to enact new rules without recourse to any procedures prescribed by old rules. See JefFerson's MaNual, H.R. Doc. No. 398, 96th Cong., 2 d Sess. $\S 388$, at 170 (1981). Unlike the Senate, which considers itself a "continuing body," the House is elected anew each session of Congress.

393. GRH 1985, supra note $10, \S 271$ (c) note (codified with some differences in language at 2 U.S.C. $\$ 901$ note (Supp. IV 1986)) (amended 1987):

This Act and the amendments made by this Act, other than those relating to the activities of the executive and judicial branches of the Government, are enacted by the Congress-

(1) as an exercise of the rulemaking power of the House of Representatives and the Senate, respectively, ...; and

(2) with full recognition of the constitutional right of either House to change such rules (so far as relating to such House) at any time, in the same manner and to the same extent as in the case of any other rule of such House.

394. U.S. CONST. art. I, § 5.

395. See generally Note, supra note 105 (arguing that each House has inherent power over its own rules that cannot be constrained by statute).

396. See id. at 855-59.

397. Even if the annual budget resolution were enacted as a joint, rather than a concurrent, resolution, it would not legally bind Congress; that is, Congress could still enact appropriations and other spending legislation inconsistent with the terms of the resolution. However, enacting the 
GRH is not itself an act of great political will; rather, it is a strategy to encourage the future exercise of political will to reduce the deficit. GRH now purports to guarantee a balanced budget by FY 1992. But this guarantee is no more enforceable than the original guarantee of a balanced budget by FY 1990. Short of a constitutional amendment restricting legislative spending power-itself a dubious proposition-a deficit limit can only increase the political constraints on spending growth. Far from representing an improper intrusion on legislative power, GRH is an expression of that power. Yet GRH, by itself, does not renegotiate the political choices that have led to growing deficits; only Congress and tlie President, acting year after year, can do that.

congressional budget resolution in the form of legislation would make the resolution politically more powerful, constituting not only the resolve of Congress but also an agreement between Congress and the President. Cf. 1988 CoNG. Q., March 12, 1988, at 627, 629 (discussing "budget summit" agreement for FY 1989, between President and congressional leadership). 


\section{CALIFORNIA LAW REVIEW \\ VOLUME LXXVI \\ MAY}

\section{COMMENTS}

SchOOL OF LaW, Boalt Hall

UNIVERSITY OF CALIFORNIA

Berkeley, CALIForNia

1988

Copyright (C) 1988 by California' Law Review, Inc. 
• 